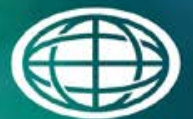

Savannah River

National Laboratory ${ }^{m}$

OPERATED BY SAVANNAH RIVER NUCLEAR SOLUTIONS

\title{
All-Pathways Dose Analysis for the Portsmouth On-Site Waste Disposal Facility (OSWDF)
}

F. G. Smith, III

M. A. Phifer

April 2014

SRNL-STI-2014-00130, Revision 0 
SRNL-STI-2014-00130

Revision 0

\section{DISCLAIMER}

This work was prepared under an agreement with and funded by the U.S. Government. Neither the U.S. Government or its employees, nor any of its contractors, subcontractors or their employees, makes any express or implied:

1. warranty or assumes any legal liability for the accuracy, completeness, or for the use or results of such use of any information, product, or process disclosed; or

2. representation that such use or results of such use would not infringe privately owned rights; or

3. endorsement or recommendation of any specifically identified commercial product, process, or service.

Any views and opinions of authors expressed in this work do not necessarily state or reflect those of the United States Government, or its contractors, or subcontractors.

\section{Printed in the United States of America \\ Prepared for U.S. Department of Energy}




\section{All-Pathways Dose Analysis for the Portsmouth On-Site Waste Disposal Facility (OSWDF)}

F. G. Smith, III

M. A. Phifer

April 2014

Prepared for the U.S. Department of Energy under contract number DE-AC09-08SR22470. 


\section{REVIEWS AND APPROVALS}

\section{AUTHORS:}

F. G. Smith, Computational Sciences

Date

M. A. Phifer, Radiological Performance Assessment

Date

TECHNICAL REVIEW:

G. A. Taylor, Radiological Performance Assessment, Reviewed per E7 2.60

Date

APPROVAL:

D. A. Crowley, Manager

Date

Radiological Performance Assessment

R. S. Aylward, Manager

Date

Environmental Restoration Technology 
SRNL-STI-2014-00130

Revision 0

\section{EXECUTIVE SUMMARY}

A Portsmouth On-Site Waste Disposal Facility (OSWDF) All-Pathways analysis has been conducted that considers the radiological impacts to a resident farmer. It is assumed that the resident farmer utilizes a farm pond contaminated by the OSWDF to irrigate a garden and pasture and water livestock from which food for the resident farmer is obtained, and that the farmer utilizes groundwater from the Berea sandstone aquifer for domestic purposes (i.e. drinking water and showering).

As described by FBP 2014b the Hydrologic Evaluation of Landfill Performance (HELP) model (Schroeder et al. 1994) and the Surface Transport Over Multiple Phases (STOMP) model (White and Oostrom 2000, 2006) were used to model the flow and transport from the OSWDF to the Points of Assessment (POAs) associated with the 680-ft elevation sandstone layer (680 SSL) and the Berea sandstone aquifer. From this modeling the activity concentrations radionuclides were projected over time at the POAs. The activity concentrations were utilized as input to a GoldSim ${ }^{\mathrm{TM}}$ (GTG 2010) dose model, described herein, in order to project the dose to a resident farmer over time.

A base case and five sensitivity cases were analyzed. The sensitivity cases included an evaluation of the impacts of using a conservative inventory, an uncased well to the Berea sandstone aquifer, a low waste zone uranium distribution coefficient $\left(\mathrm{K}_{\mathrm{d}}\right)$, different transfer factors, and reference person exposure parameters (i.e. at 95 percentile). The maximum base case dose within the 1,000 year assessment period was projected to be $1.5 \mathrm{E}-14 \mathrm{mrem} / \mathrm{yr}$, and the maximum base case dose at any time less than 10,000 years was projected to be $0.002 \mathrm{mrem} / \mathrm{yr}$. The maximum projected dose of any sensitivity case was approximately $2.6 \mathrm{mrem} / \mathrm{yr}$ associated with the use of an uncased well to the Berea sandstone aquifer. This sensitivity case is considered very unlikely because it assumes leakage from the location of greatest concentration in the $680 \mathrm{SSL}$ in to the Berea sandstone aquiver over time and does not conform to standard private water well construction practices.

The bottom-line is that all predicted doses from the base case and five sensitivity cases fall well below the DOE all-pathways 25 mrem/yr Performance Objective. 


\section{TABLE OF CONTENTS}

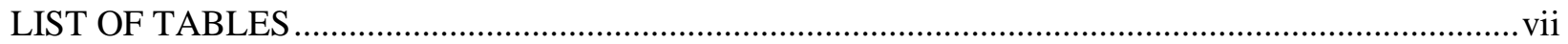

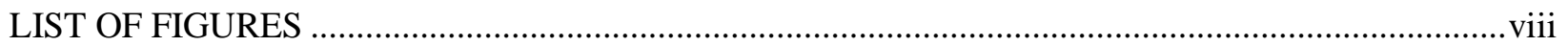

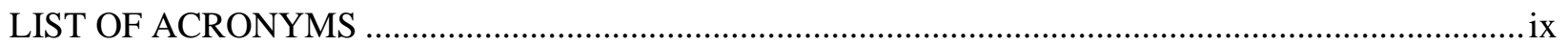

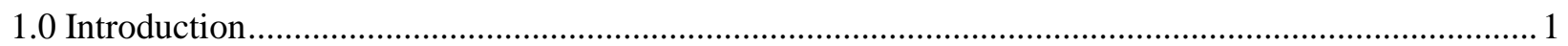

2.0 All-Pathways Exposure Scenarios and Dose Equations ............................................................... 1

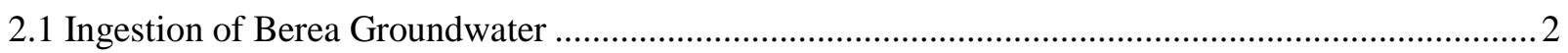

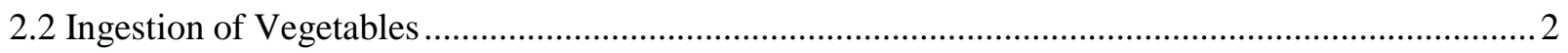

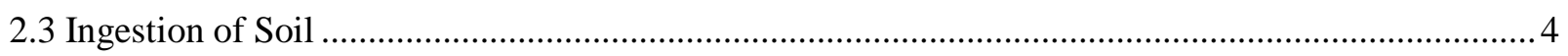

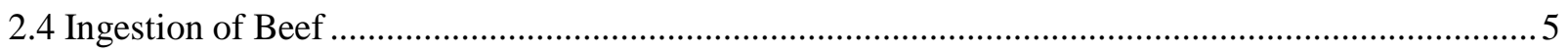

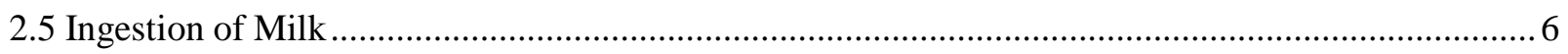

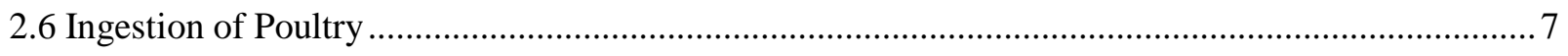

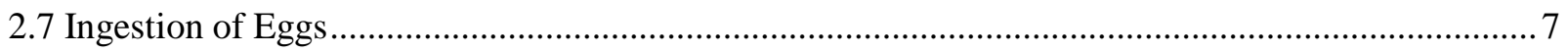

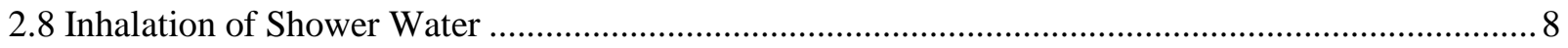

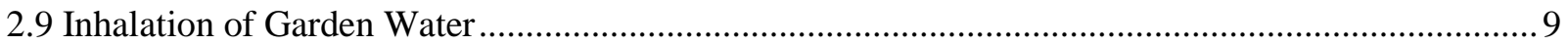

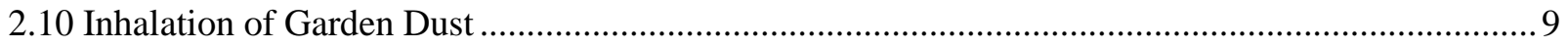

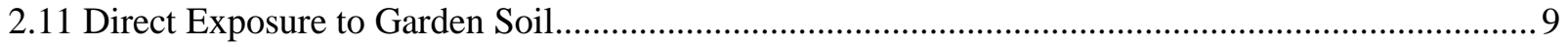

3.0 Portsmouth OSWDF GoldSim All-Pathways Dose Model .............................................................. 10

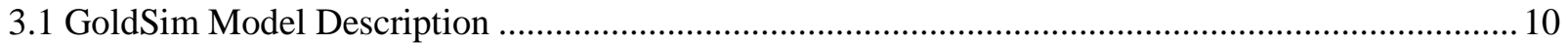

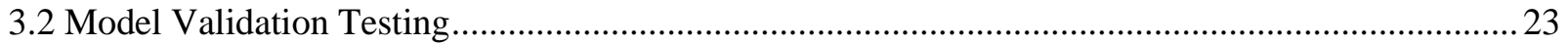

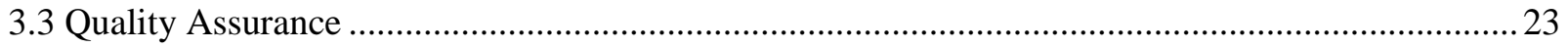

4.0 Portsmouth OSWDF STOMP Model Input to All-Pathways Dose Model......................................... 23

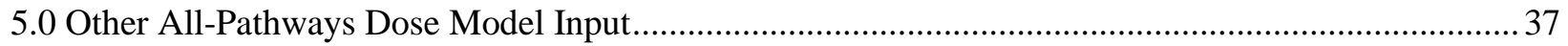

6.0 Portsmouth OSWDF All-Pathways Dose Model Runs and Results ...................................................57

6.1 OSWDF Inventory Constraints Based on All-Pathways Dose Analysis.........................................69

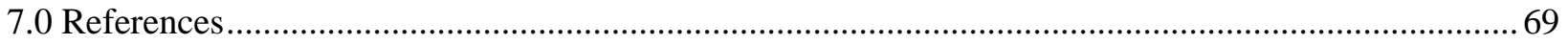




\section{LIST OF TABLES}

Table 3-1. GoldSim Model Validation Test Results............................................................................ 23

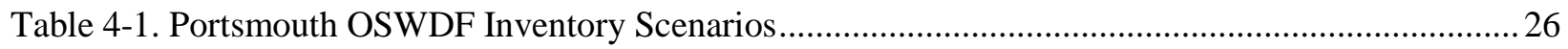

Table 4-2. Portsmouth OSWDF STOMP Model Input to All-Pathways Dose Model .............................. 28

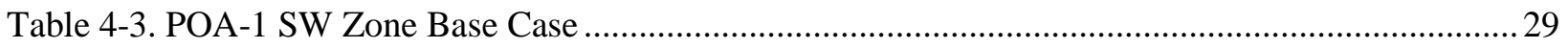

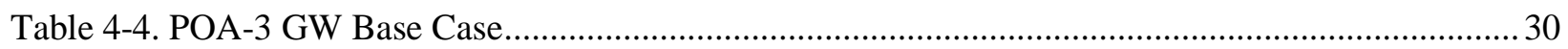

Table 4-5. POA-1 SW Zone Sensitivity Case \#1 ....................................................................................... 31

Table 4-6. POA-3 GW Sensitivity Case \#1 ......................................................................................... 32

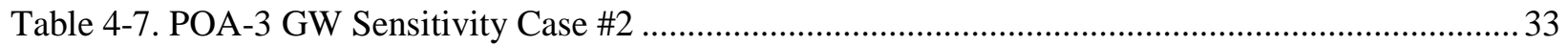

Table 4-8. POA-1 SW Zone Sensitivity Case \#3 ........................................................................................ 34

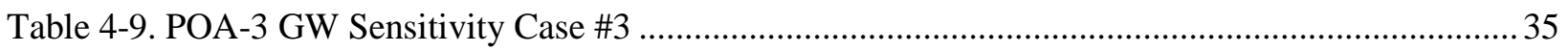

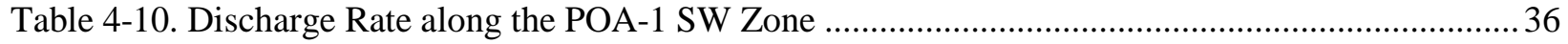

Table 5-1. Ohio Net Irrigation Water Requirements (USDA 1970) ........................................................ 38

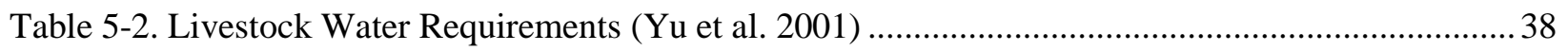

Table 5-3. Resident Farm Size (Yu et al. 2001)..................................................................................... 38

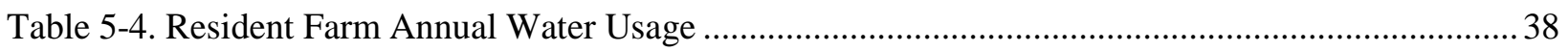

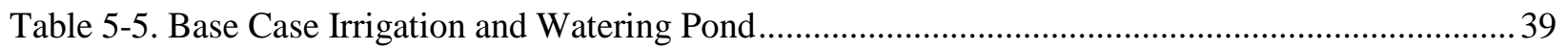

Table 5-6. Senstivity Case \#1 Irrigation and Watering Pond...................................................................... 40

Table 5-7. Sensitivity Case \#3 Irrigation and Watering Pond ................................................................ 41

Table 5-8. Portsmouth OSWDF Decay Chains - Half-lives and Branching Fractions ............................. 42

Table 5-9. Ingestion and Inhalation Dose Coefficients and External Soil Exposure Factors .................... 46

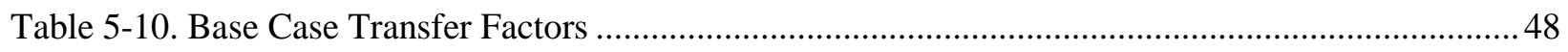

Table 5-11. Sensitivity Case \#4 Transfer Factors ...................................................................................... 50

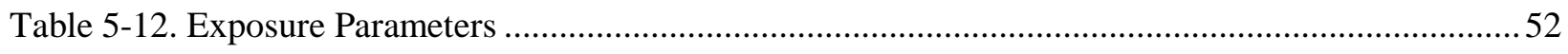

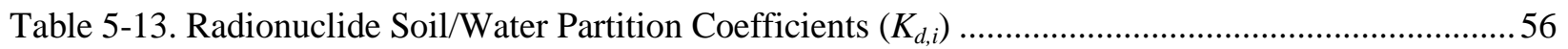

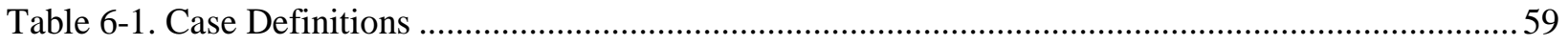

Table 6-2. Summary of Results from All-Pathways Dose Calculations ................................................ 60

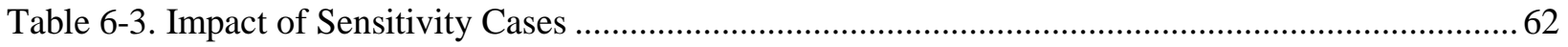




\section{LIST OF FIGURES}

Figure 3-1. Contents of Upper Level Container in Goldsim Portsmouth All-Pathways Dose Model........ 11

Figure 3-2. View of Model_Options Dashboard Showing User Options ................................................ 12

Figure 3-3. Expanded View of Input Container...................................................................................... 13

Figure 3-4. Expanded View of Decay_Chains Container ....................................................................... 14

Figure 3-5. Expanded View of Dose_Model Container......................................................................... 15

Figure 3-6. Expanded view of Dose_Parameters container .................................................................... 16

Figure 3-7. Expanded View of Dose_Coefficeints Container ............................................................ 17

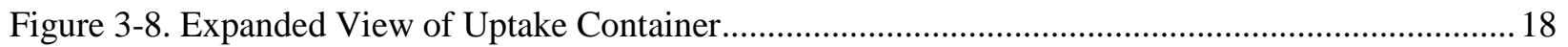

Figure 3-9. Expanded View of Ingest_Dose Container .......................................................................... 20

Figure 3-10. Expanded View of Inhale_Dose Container ..................................................................... 21

Figure 3-11. Expanded View of Direct_Dose Container .......................................................................... 22

Figure 3-12. Expanded View of Total_Dose Container............................................................................. 22

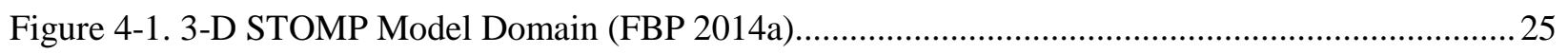

Figure 4-2. 3-D STOMP Model Vertical Representation (FBP 2014a)..................................................26

Figure 4-3. Reasonable Inventory Case Loading and POA Locations ...................................................27

Figure 4-4. Conservative Inventory Case Loading and POA Locations..................................................2

Figure 5-1. Technetium-99 Decay to Stable Progeny ............................................................................... 43

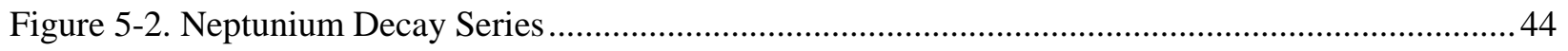

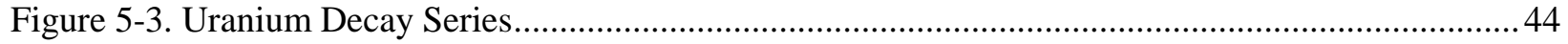

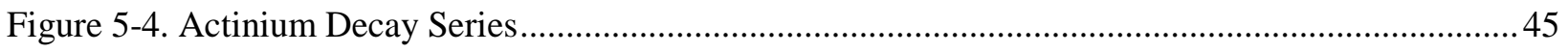

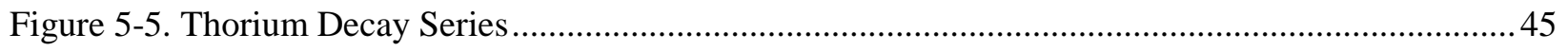

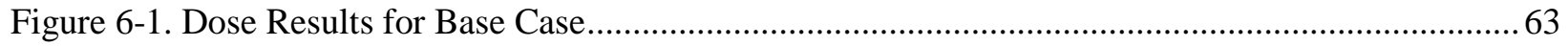

Figure 6-2. Dose Results for Sensitivity Case \#1 with a Conservative Inventory ....................................64

Figure 6-3. Dose Results for Sensitivity Case \#2 with Contaminated Well Water from the Berea Aquifer

Figure 6-4. Dose Results for Sensitivity Case \#3 with Lower Uranium $\mathrm{K}_{\mathrm{d}}$ in the Waste Zone.................. 66

Figure 6-5. Dose Results for Sensitivity Case \#4 with IAEA Transfer Factors.......................................67 


\section{LIST OF ACRONYMS}

\begin{tabular}{|l|l|}
\hline $3-D$ & three-dimensional \\
\hline 680 SSL & 680-ft elevation sandstone layer \\
\hline ARF & airborne release fraction \\
\hline DC & dose coefficient \\
\hline DCF & dose coefficient factor \\
\hline D\&D & decontamination and decommissioning \\
\hline DOE & Department of Energy \\
\hline EPA & Environmental Protection Agency \\
\hline FBP & Fluor-B\&W Portsmouth LLC \\
\hline FFS & Fluor Federal Services \\
\hline GTG & GoldSim Technology Group LLC \\
\hline GW & groundwater \\
\hline HELP & Hydrologic Evaluation of Landfill Performance \\
\hline IAEA & International Atomic Energy Agency \\
\hline ICRP & International Commission on Radiological Protection \\
\hline K & soil/water partition coefficient \\
\hline OSWDF & On-Site Waste Disposal Facility \\
\hline PA & Performance Assessment \\
\hline POA & Point of Assessment \\
\hline PNNL & Pacific Northwest National Laboratory \\
\hline RESRAD & Residual Radioactivity (model) \\
\hline RI/FS & Remedial Investigation and Feasibility Study \\
\hline SRNL & Savannah River National Laboratory \\
\hline SRR & Savannah River Remediation \\
\hline SRS & Savannah River Site \\
\hline STOMP & Surface Transport Over Multiple Phases \\
\hline SW & surface water \\
\hline TED & total effective dose \\
\hline USDA & United States Department of Agriculture \\
\hline
\end{tabular}


SRNL-STI-2014-00130

Revision 0

Intentionally Blank 


\subsection{Introduction}

An On-Site Alternative is being evaluated as part of the Waste Disposal (WD) Remedial Investigation and Feasibility Study (RI/FS) process for evaluation of alternatives for the disposal of waste generated from decontamination and decommissioning (D\&D) at the Portsmouth Gaseous Diffusion Plant, Piketon, Ohio. The On-Site Alternative involves construction of an On-Site Waste Disposal Facility (OSWDF) (FBP 2014a). As part of Department of Energy (DOE) Order 435.1, Radioactive Waste Management (DOE 1999a and DOE 1999b), an All-Pathways analysis must be conducted for the OSWDF. Allpathways analyses evaluate the potential dose to the public outside the bounds of the disposal facility and typically include exposure pathways associated with groundwater use (e.g. consumption and irrigation). The performance objective for the all-pathways analysis is to provide a reasonable expectation that the dose to a hypothetical future member of the public will not exceed 25 mrem total effective dose in a year (DOE 2013).

The Portsmouth OSWDF All-Pathways analysis considers the radiological impacts to a resident farmer. It is assumed that the resident farmer utilizes a farm pond contaminated by the OSWDF to irrigate a garden and pasture and water livestock from which food for the resident farmer is obtained, and that the farmer utilizes groundwater from the Berea sandstone aquifer for domestic purposes (i.e. drinking water and showering).

This report is divided into the following primary sections:

- All-Pathways Exposure Scenarios and Dose Equations

- Portsmouth OSWDF GoldSim All-Pathways Dose Model

- Portsmouth OSWDF STOMP Model Input to All-Pathways Dose Model

- Other All-Pathways Dose Model Input

- Portsmouth OSWDF All-Pathways Dose Model Runs and Results

\subsection{All-Pathways Exposure Scenarios and Dose Equations}

Two potential migration pathways for contaminant release from the Portsmouth OSWDF and exposure by a hypothetical resident farmer have been identified (FBP 2014a). The potential migration pathways include:

- Outcrop to the ground surface from the continuous 2-ft sandstone layer (i.e. 680-ft elevation sandstone layer (680 SSL)) that occurs in the middle of the Cuyahoga shale, and

- Migration to the underlying Berea sandstone aquifer.

The hypothetical resident farmer exposure scenario involves the use of contaminated water associated with the two migration pathways as follows:

- It is assumed that the contaminated groundwater seeping from the 680 SSL outcrop is captured by a farm pond which is used to irrigate a garden and pasture and water livestock from which food for the resident farmer is obtained.

- It is assumed that groundwater from the Berea sandstone aquifer is utilized for domestic purposes (i.e. drinking water and showering).

The exposure scenarios associated with use of the farm pond are assumed to include: 
SRNL-STI-2014-00130

Revision 0

- Ingestion of Vegetables

- Ingestion of Soil

- Ingestion of Beef

- Ingestion of Milk

- Ingestion of Poultry

- Ingestion of Eggs

- Inhalation of Garden Water

- Inhalation of Garden Dust

- Direct Exposure to Garden Soil

The exposure scenarios associated with use of Berea groundwater are assumed to include:

- Ingestion of Berea Groundwater

- Inhalation of Shower Water

Sections 2.1 through 2.11 provide a more detailed description of each exposure scenario assumed and the equations used to calculate the associated dose. As shown, the dose equations are for a single radionuclide. The total dose for each pathway is the summation of the doses from each radionuclide.

\subsection{Ingestion of Berea Groundwater}

The exposure route for water ingestion assumes that the receptor uses a Berea well as a drinking water source. The dose from consumption of drinking water was calculated using the following formula.

$$
\begin{aligned}
& D_{i, w}=C_{i, G W} \times U_{w} \times D C_{i, w} \\
& \text { where } \\
& D_{i, w} \text {............ annual total effective dose (TED) to an individual from groundwater ingestion for } \\
& \text { radionuclide i (mrem/yr) (calculated value) } \\
& C_{i, G W} \text {.......... concentration of radionuclide i in Berea groundwater (pCi/L) (see Tables 4-4, 4-6, 4- } \\
& \text { 7, and 4-9) }
\end{aligned}
$$

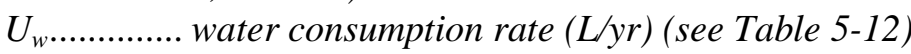

$$
\begin{aligned}
& D C_{i, w} \ldots \ldots . . . . . . . \text { water ingestion dose coefficient for radionuclide i (mrem/pCi) (see Table 5-9) }
\end{aligned}
$$

\subsection{Ingestion of Vegetables}

The exposure route for vegetable ingestion assumes that the receptor consumes contaminated leafy vegetables and produce. It is assumed that the vegetables are contaminated through the following two routes: 1) direct deposition of contaminated irrigation water on plants; and 2) deposition of contaminated irrigation water on soil followed by root uptake by plants. The irrigation water is assumed to be taken from a pond that is contaminated by seepage from the 680 sandstone layer. The buildup of radionuclide concentration in the soil from successive years of irrigation is taken into account. Leafy vegetables and produce are treated separately. The radionuclide concentration in the vegetables and the dose is calculated using the following formulas.

$$
D_{i, v}=C_{i, v} \times f_{v} \times\left[U_{V}+\left(U_{L} \times f_{p}\right)\right] \times D C_{i, w}
$$


where

$D_{i, v}$.............. annual TED from radionuclide i to an individual from ingestion of vegetables grown in a garden irrigated with contaminated water (mrem/yr) (calculated value)

$C_{i, v}$............. concentration of radionuclide $i$ in vegetables from irrigated garden ( $\left.\mathrm{pCi} / \mathrm{kg}\right)$ (calculated value)

$f_{v}$................ fraction of vegetables from contaminated garden (unitless) (see Table 5-12)

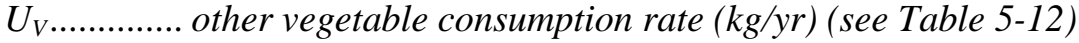

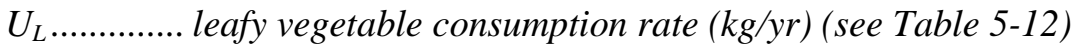

$f_{p}$................ fraction of material deposited on plant surface that is retained after washing (applies only to leafy vegetables) (unitless) (see Table 5-12)

$D C_{i, w} \ldots . . . . . . .$. water ingestion dose coefficient for radionuclide i (mrem/pCi) (see Table 5-9)

$C_{i, v}=C_{i, I W P} \times I \times\left[L E A F+\left(f_{i r r} \times B_{i, v} \times S O I L\right)\right] \times e^{-\lambda_{i} t_{v}}$

where

$C_{i, I W P}$........... concentration of radionuclide $i$ in irrigation and watering pond $(\mathrm{pCi} / \mathrm{L})($ see Tables 5-5, 5-6, and 5-7)

I................ garden and pasture irrigation rate $\left(\mathrm{L} / \mathrm{d} / \mathrm{m}^{2}\right)$ (could have different values for garden and pasture; however, for Portsmouth dose calculations it is assumed that the garden and pasture irrigation rate are the same) (see Table 5-12)

$L E A F$......... radionuclide deposition and retention rate on the leaves $\left(\mathrm{m}^{2} \mathrm{~d} / \mathrm{kg}\right)$ (calculated value)

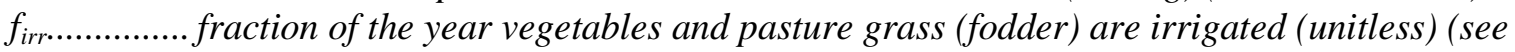
Table 5-12)

$B_{i, v}$............. soil-to-vegetable transfer factor for radionuclide i (unitless) (see Tables 5-10 and 511)

SOIL .......... radionuclide deposition and buildup rate in the soil $\left(\mathrm{m}^{2} \mathrm{~d} / \mathrm{kg}\right)$ (calculated value)

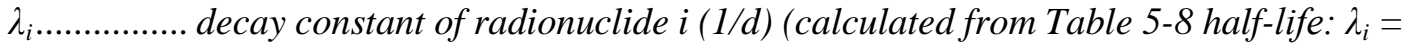
$\operatorname{Ln} 2 / t_{1 / 2}$ )

$t_{v}$................. harvest to consumption time for vegetables (d) (see Table 5-12)

$L E A F=\frac{r \times\left(1-e^{-\lambda_{e} t_{i r r}}\right)}{Y_{v p g} \times \lambda_{e}}$

$\lambda_{e}=\lambda_{i}+\lambda_{w}$

where

r................ fraction of material deposited on plant surface that is retained (i.e., accounts for plant runoff during and immediately following irrigation) (unitless) (see Table 5-12)

$\lambda_{e}$................. weathering and radiological decay constant (1/d) (calculated value)

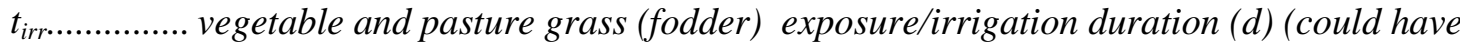
different values for garden and pasture; however, for Portsmouth dose calculations it is assumed that the garden and pasture are irrigated for the same length of time) (see Table 5-12)

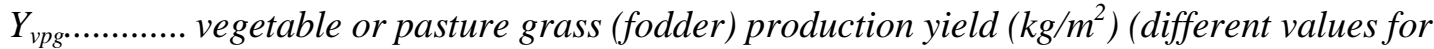
vegetable and pasture grass (fodder)) (see Table 5-12)

$\lambda_{i}$................ decay constant of radionuclide $i(1 / d)$ (calculated from Table 5-8 half-life: $\lambda_{i}=$ $\left.\operatorname{Ln} 2 / t_{1 / 2}\right)$ 
SRNL-STI-2014-00130

Revision 0

$\lambda_{w} \ldots \ldots . . . . . . . . . . w e a t h e r i n g ~ c o n s t a n t ~(1 / d)$ (see Table 5-12)

$S O I L=\frac{1-e^{-\lambda_{s, i} t_{s}}}{\rho_{S} \times \lambda_{s, i}}$

where

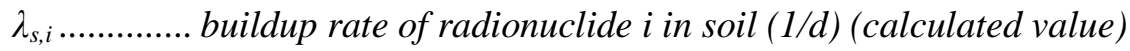

$t_{s}$................ buildup time of radionuclides in soil (25 years) (d) (see Table 5-12)

$\rho_{s} \ldots \ldots \ldots \ldots . . . . .$. soil areal density $\left(\mathrm{kg} / \mathrm{m}^{2}\right)$ (see Table 5-12)

$\lambda_{s, i}=\lambda_{i}+\lambda_{K, i}$

where

$\lambda_{i} \ldots \ldots \ldots . . . . . . .$. decay constant of radionuclide $i(1 / d)$ (calculated from Table 5-8 half-life: $\lambda_{i}=$ $\operatorname{Ln} 2 / t_{1 / 2}$ )

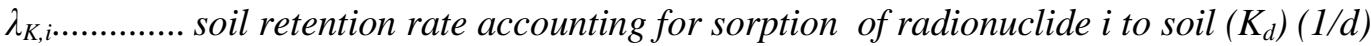

(calculated value)

$\lambda_{K, i}=\frac{P+\left(I \times f_{i r r}\right)-E}{d_{g} \times\left[\theta_{w}+\left(\rho_{s} \times K_{d, i}\right)\right]}$

where

P............... precipitation rate $\left(\mathrm{L} / \mathrm{d} / \mathrm{m}^{2}\right)$ (see Table 5-12)

I................ garden and pasture irrigation rate $\left(\mathrm{L} / \mathrm{d} / \mathrm{m}^{2}\right)$ (see Table 5-12)

firr.............. fraction of the year vegetables and pasture grass (fodder) are irrigated (unitless) (see Table 5-12)

E ............... evaporation transpiration rate $\left(\mathrm{L} / \mathrm{d} / \mathrm{m}^{2}\right)$ (see Table $\left.5-12\right)$

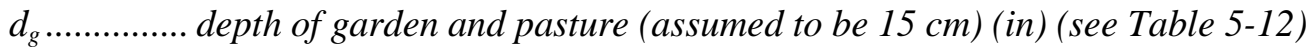

$\theta_{w}$................ volumetric water content of soil (unitless) (see Table 5-12)

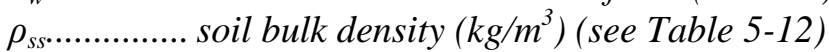

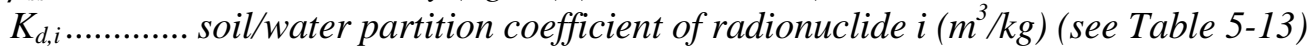

\subsection{Ingestion of Soil}

The exposure route for soil ingestion assumes that the receptor consumes contaminated soil from the garden, which has been irrigated with contaminated water. The irrigation water is assumed to be taken from a pond that is contaminated by seepage from the 680 sandstone layer. The buildup of radionuclide concentration in the soil from successive years of irrigation is taken into account. The radionuclide concentration in the soil and the dose is calculated using the following formulas.

$D_{i, s(g)}=C_{i, s(g)} \times U_{s(g)} \times f_{Y r(g)} \times D C_{i, w}$

where

$D_{i, s(g)}$.......... annual TED to an individual from soil ingestion for radionuclide i from working in vegetable garden (mrem/yr) (calculated value) 
$C_{i, s(g)}$........... concentration of radionuclide $i$ in soil from irrigation of vegetable garden $(\mathrm{pCi} / \mathrm{kg})$ (calculated value)

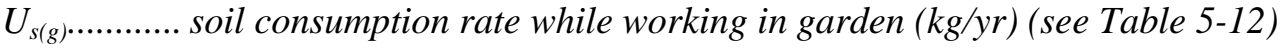

$f_{y r(g)}$............. fraction of year spent working in vegetable garden (unitless) (see Table 5-12)

$D C_{i, w} \ldots . . . . . . .$. water ingestion dose coefficient for radionuclide i (mrem/pCi) (see Table 5-9)

$C_{i, s(g)}=C_{i, I W P} \times I \times f_{\text {irr }} \times S O I L$

where

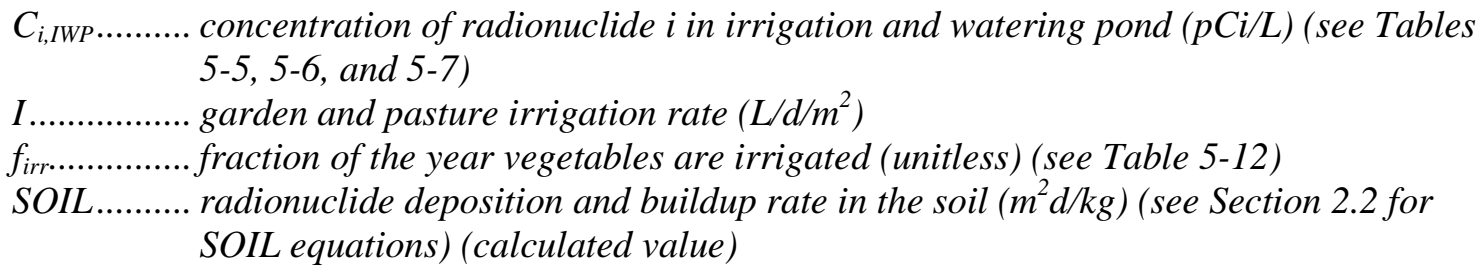

\subsection{Ingestion of Beef}

The exposure route for beef ingestion assumes that the receptor consumes contaminated beef from cattle that are watered with contaminated stock water and consume fodder irrigated with contaminated water. The stock water and irrigation water is assumed to be taken from a pond that is contaminated by seepage from the 680 sandstone layer. The fodder is contaminated from direct deposition of contaminated irrigation water on plants and from deposition of contaminated irrigation water in soil followed by root uptake by plants. The buildup of radionuclide concentration in the soil from successive years of irrigation is taken into accounted. The radionuclide concentration in the beef and the dose is calculated using the following formulas.

$D_{i, b}=C_{i, b} \times U_{b} \times f_{b} \times D C_{i, w}$

where

$D_{i, b}$............. annual TED to an individual from beef ingestion for radionuclide i (mrem/yr) (calculated value)

$C_{i, b}$.............. concentration of radionuclide i in beef ( $\mathrm{pCi} / \mathrm{kg}$ ) (calculated value)

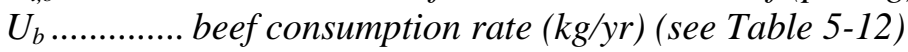

$f_{b}$................ fraction of beef from cows raised on affected pasture (unitless) (see Table 5-12)

$D C_{i, w} \ldots \ldots . . . . .$. water ingestion dose coefficient for radionuclide i (mrem/pCi) (see Table 5-9)

$C_{i, b}=F_{i, b} \times\left[\left(f_{f b} \times C_{i, f} \times Q_{f b}\right)+\left(f_{c w b} \times C_{i, I W P} \times Q_{w b}\right)\right] \times e^{-\lambda_{i} t_{b}}$

where

$F_{i, b}$.............. Feed-to-beef transfer factor for radionuclide i (d/kg) (see Tables 5-10 and 5-11)

$f_{f b}$................ Fraction of fodder taken from irrigated pasture (beef cow) (unitless) (see Table 5-12)

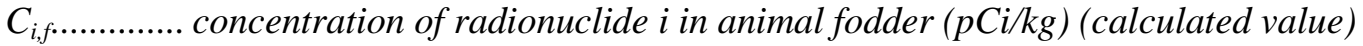

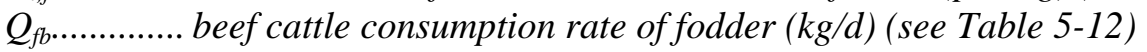

$f_{c w b}$............. fraction of water for beef cows from contaminated water (unitless) (see Table 5-12)

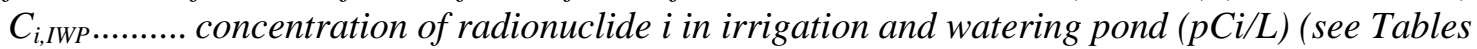
5-5, 5-6, and 5-7) 
SRNL-STI-2014-00130

Revision 0

$Q_{w b}$............. beef cow consumption rate of water $(L / d)$ (see Table 5-12)

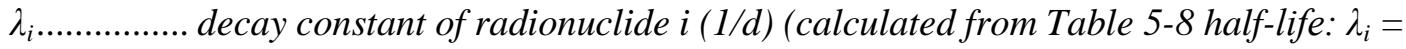
$\operatorname{Ln} 2 / t_{1 / 2}$ )

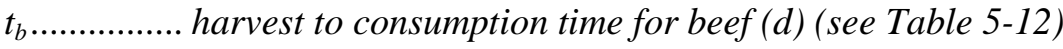

$C_{i, f}=C_{i, I W P} \times I \times\left[L E A F+\left(f_{i r r} \times B_{i, v} \times S O I L\right)\right]$

where

$C_{i, I W P} \ldots . . . . . . . .$. concentration of radionuclide $i$ in irrigation and watering pond $(p C i / L)($ see Tables 5-5, 5-6, and 5-7)

I................ irrigation rate $\left(\mathrm{L} / \mathrm{d} / \mathrm{m}^{2}\right)$ (see Table 5-12)

$L E A F$......... radionuclide deposition and retention rate on the leaves $\left(\mathrm{m}^{2} \mathrm{~d} / \mathrm{kg}\right)$ (see Section 2.2 for LEAF equations) (different production yield values, $Y_{v p g}$, for vegetable and pasture grass (fodder)) (calculated value)

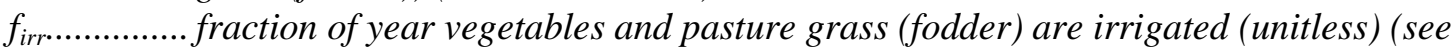
Table 5-12)

$B_{i, v}$............. soil-to-vegetable transfer factor for radionuclide i (unitless) (see Tables 5-10 and 511)

SOIL .......... radionuclide deposition and buildup rate in the soil $\left(\mathrm{m}^{2} \mathrm{~d} / \mathrm{kg}\right.$ ) (see Section 2.2 for SOIL equations) (calculated value)

\subsection{Ingestion of Milk}

The exposure route for milk ingestion assumes that the receptor consumes contaminated milk from milk cows, which are watered with contaminated stock water and consume fodder irrigated with contaminated water. The stock water and irrigation water is assumed to be taken from a pond that is contaminated by seepage from the 680 sandstone layer. The fodder is contaminated from direct deposition of contaminated irrigation water on plants and from deposition of contaminated irrigation water in soil followed by root uptake by plants. The buildup of radionuclide concentration in the soil from successive years of irrigation is taken into accounted. The radionuclide concentration in the milk and the dose is calculated using the following formulas.

$D_{i, m}=C_{i, m} \times U_{m} \times f_{m} \times D C_{i, w}$

where

$D_{i, m}$............ annual TED to an individual from milk ingestion for radionuclide i ( $\mathrm{mrem} / \mathrm{yr}$ ) (calculated value)

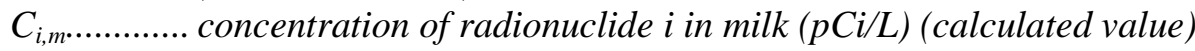

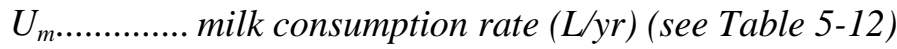

$f_{m}$................ fraction of milk from cows raised on affected pasture (unitless) (see Table 5-12)

$D C_{i, w} \ldots . . . . . . .$. water ingestion dose coefficient for radionuclide i (mrem/pCi) (see Table 5-9)

$C_{i, m}=F_{i, m} \times\left[\left(f_{f m} \times C_{i, f} \times Q_{f, m}\right)+\left(f_{c w m} \times C_{i, I W P} \times Q_{w m}\right)\right] \times e^{-\lambda_{i} t_{m}}$

where

$F_{i, m}$............... Feed-to-milk transfer factor for radionuclide i (d/L) (see Tables 5-10 and 5-11)

$f_{\text {fm }}$................ Fraction of fodder taken from irrigated pasture (milk cow) (unitless) (see Table 5-12) 


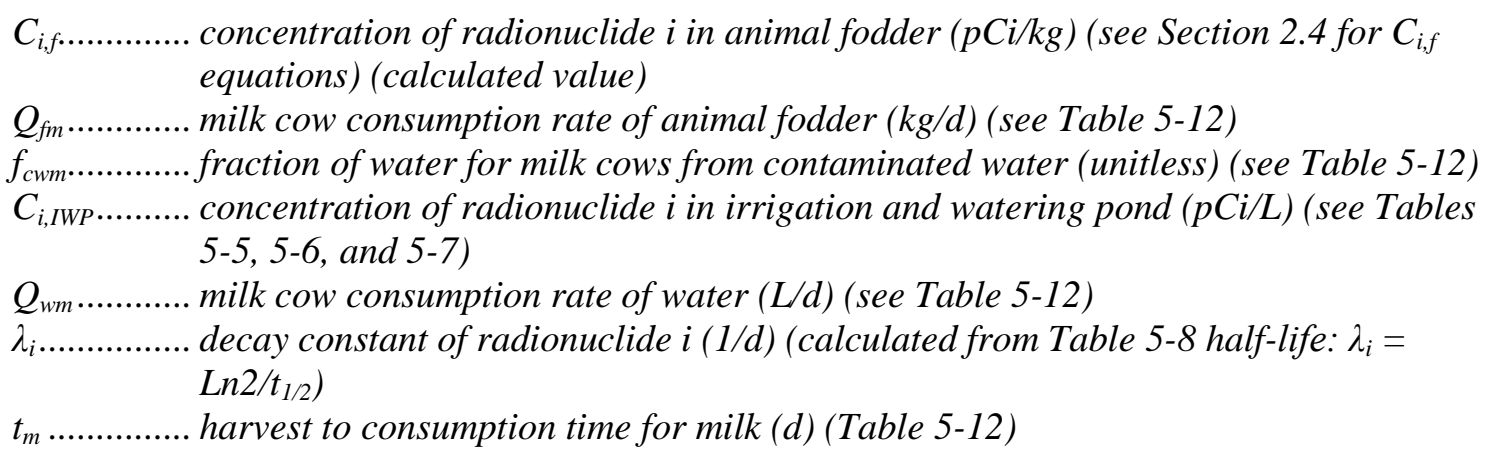

\subsection{Ingestion of Poultry}

The exposure route for poultry ingestion assumes that the receptor consumes contaminated poultry, which are watered with contaminated stock water and consume fodder irrigated with contaminated water. The stock water and irrigation water is assumed to be taken from a pond that is contaminated by seepage from the 680 sandstone layer. The fodder is contaminated from direct deposition of contaminated irrigation water on plants and from deposition of contaminated irrigation water in soil followed by root uptake by plants. The buildup of radionuclide concentration in the soil from successive years of irrigation is taken into accounted. The radionuclide concentration in the poultry and the dose is calculated using the following formula.

$$
D_{i, p}=F_{i, p} \times\left[\left(f_{f p} \times C_{i, f} \times Q_{f p}\right)+\left(f_{c w p} \times C_{i I W P} \times Q_{w p}\right)\right] \times D C_{i, w} \times U_{P} \times f_{P} \times e^{-\lambda_{i} t_{p}}
$$

where

$$
\begin{aligned}
& D_{i, p} \text {............. annual TED to an individual from poultry ingestion for radionuclide i ( } \mathrm{mrem} / \mathrm{yr} \text { ) } \\
& \text { (calculated value) } \\
& F_{i, p} \text {.............. feed-to-poultry transfer factor for radionuclide i }(\mathrm{d} / \mathrm{kg}) \text { (see Tables 5-10 and 5-11) } \\
& f_{f p} \text {................ fraction of fodder taken from irrigated pasture (poultry) (unitless) (see Table 5-12) }
\end{aligned}
$$

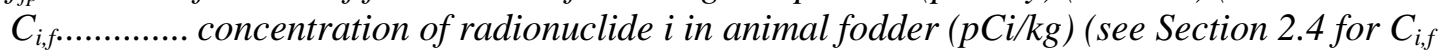

$$
\begin{aligned}
& \text { equations) (calculated value) }
\end{aligned}
$$

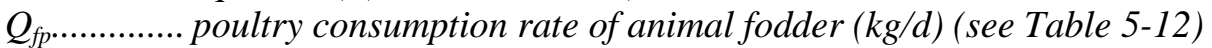

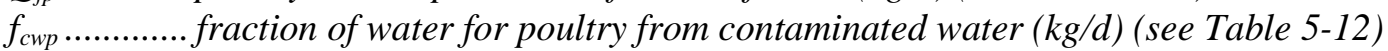

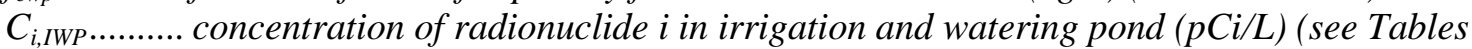

$$
\begin{aligned}
& \text { 5-5, 5-6, and 5-7) }
\end{aligned}
$$

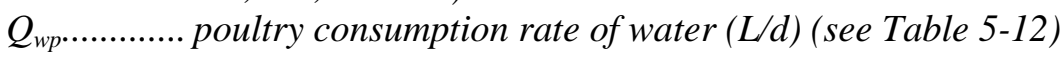

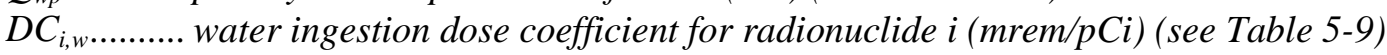

$$
\begin{aligned}
& U_{p} \text {.............. human consumption rate of poultry ( } \mathrm{kg} / \mathrm{yr} \text { ) (see Table 5-12) } \\
& f_{p} \text {................ fraction of poultry raised on affected pasture (unitless) (see Table 5-12) } \\
& \lambda_{i} \text {................ decay constant of radionuclide i (1/d) (calculated from Table 5-8 half-life: } \lambda_{i}= \\
& \operatorname{Ln} 2 / t_{1 / 2} \text { ) } \\
& t_{p} \text {................ harvest to consumption time for poultry (d) (Table 5-12) }
\end{aligned}
$$

\subsection{Ingestion of Eggs}

The exposure route for egg ingestion assumes that the receptor consumes contaminated eggs obtained from hens, which were watered with contaminated stock water and consume fodder irrigated with contaminated water. The stock water and irrigation water is assumed to be taken from a pond that is contaminated by seepage from the 680 sandstone layer. The fodder is contaminated from direct 
deposition of contaminated irrigation water on plants and from deposition of contaminated irrigation water in soil followed by root uptake by plants. The buildup of radionuclide concentration in the soil from successive years of irrigation is taken into accounted. The radionuclide concentration in the eggs and the dose is calculated using the following formula.

$$
D_{i, e}=F_{i, e} \times\left[\left(f_{f p} \times C_{i, f} \times Q_{f p}\right)+\left(f_{c w p} \times C_{i, I W P} \times Q_{w p}\right)\right] \times D C_{i, w} \times U_{e} \times f_{e} \times e^{-\lambda_{i} t_{e}}
$$

where

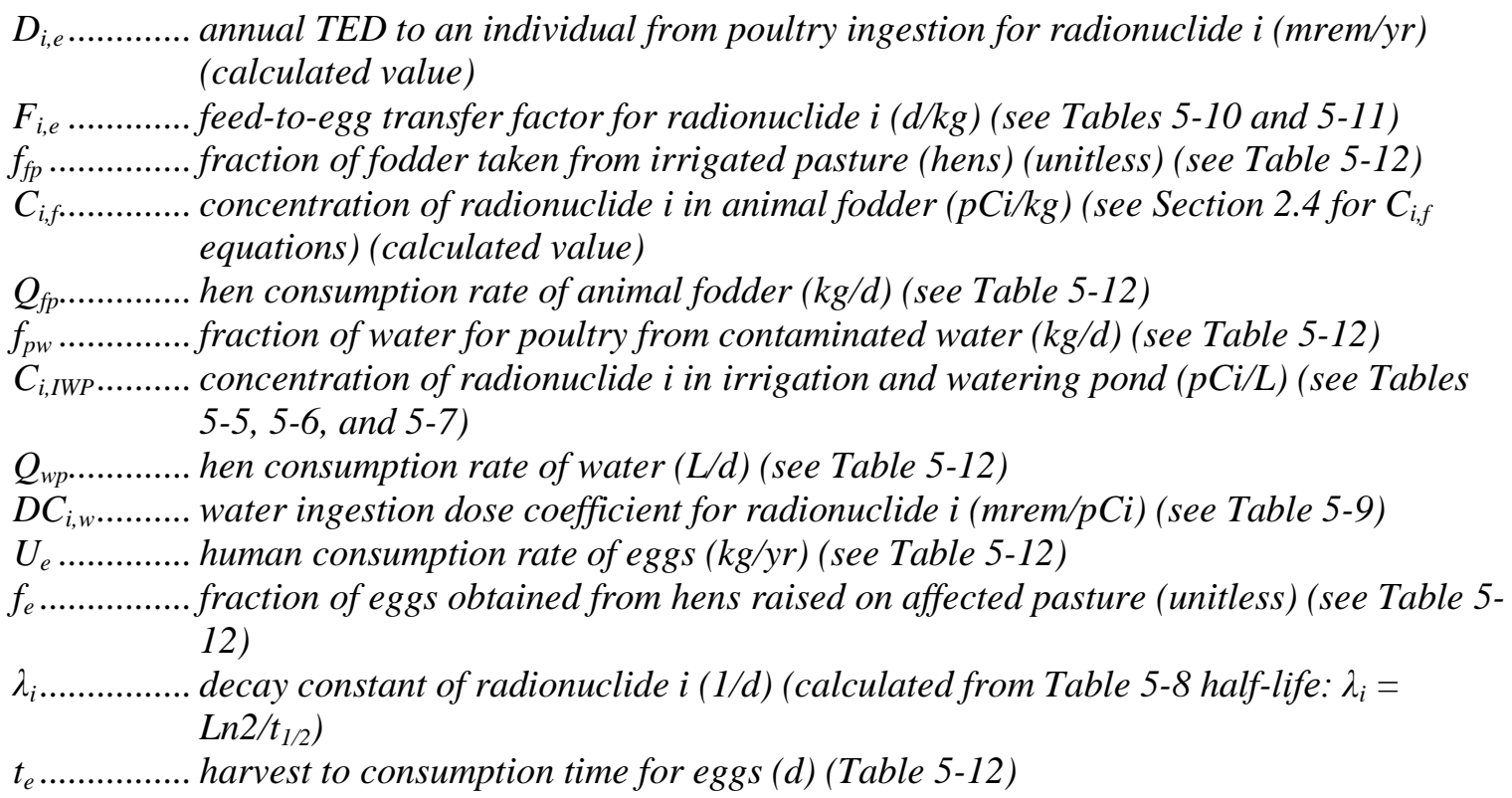

\subsection{Inhalation of Shower Water}

The exposure route for shower water inhalation assumes that the receptor inhales contaminated water during time spent showering with contaminated water from the Berea. The dose is calculated using the following formula.

$$
D_{i, a(s w)}=\frac{C_{i, G W} \times U_{a} \times t_{s} \times C_{w s} \times A R F \times D C_{i, a}}{\rho_{w}}
$$

where

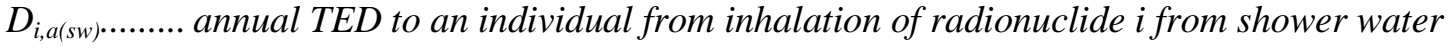

$$
\begin{aligned}
& C_{i, G W} \text {........... concentration of radionuclide } i \text { in Berea groundwater }(\mathrm{pCi} / \mathrm{L})(\mathrm{see} \text { Tables 4-4, 4-6, 4- } \\
& \text { 7, and 4-9) } \\
& U_{a} \text {.............. age-adjusted inhalation rate }\left(\mathrm{m}^{3} / \mathrm{yr}\right) \text { (see Table 5-12) } \\
& t_{s} \text {................ resident adult shower exposure time (unitless) (see Table 5-12) } \\
& C_{w s} \text {............. water contained in air at shower conditions }\left(\mathrm{g} / \mathrm{m}^{3}\right) \text { (see Table 5-12) } \\
& A R F \text {........... airborne release fraction (unitless) (see Table 5-12) } \\
& D C_{i, a} \text {........... air inhalation dose coefficient for radionuclide i (mrem/pCi) (see Table 5-9) }
\end{aligned}
$$

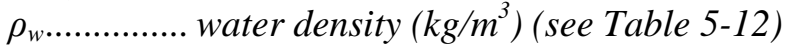




\subsection{Inhalation of Garden Water}

The exposure route for garden water inhalation assumes that the receptor inhales contaminated water during time spent caring for a garden which has been irrigated with contaminated water. The irrigation water for the garden is assumed to be taken from a pond that is contaminated by seepage from the 680 sandstone layer. The dose is calculated using the following formula.

$$
D_{i, a(g w)}=\frac{C_{i, I W P} \times U_{a} \times f_{y r(g)} \times C_{w a} \times A R F \times D C_{i, a}}{\rho_{w}}
$$

where

$$
\begin{aligned}
& D_{i, a(g w)} \text {......... annual TED to an individual from inhalation of radionuclide } i \text { from irrigation water } \\
& \text { suspended in the air (mrem/yr) (calculated value) }
\end{aligned}
$$

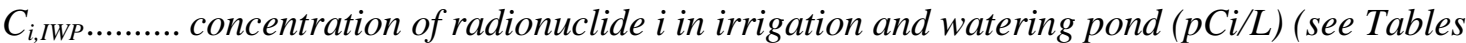

$$
\begin{aligned}
& \text { 5-5, 5-6, and 5-7) } \\
& U_{a} \ldots \ldots . . . . . . . . \text { age-adjusted inhalation rate }\left(\mathrm{m}^{3} / \mathrm{yr}\right) \text { (see Table 5-12) } \\
& f_{y r(g)} \text {............. fraction of year spent working in vegetable garden (unitless) (see Table 5-12) } \\
& C_{w a} \text {............. Water contained in air at ambient conditions }\left(\mathrm{g} / \mathrm{m}^{3}\right) \text { (see Table 5-12) } \\
& \text { ARF ........... airborne release fraction (unitless) (see Table 5-12) } \\
& \left.D C_{i, a} \text {.......... air inhalation dose coefficient for radionuclide i ( } \mathrm{mrem} / \mathrm{pCi}\right) \text { (see Table 5-9) }
\end{aligned}
$$

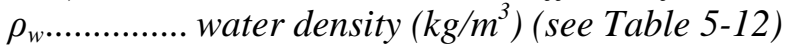

\subsection{Inhalation of Garden Dust}

The exposure route for garden dust inhalation assumes that the receptor inhales contaminated dust during time spent caring for a garden which has been irrigated with contaminated water. The irrigation water for the garden is assumed to be taken from a pond that is contaminated by seepage from the 680 sandstone layer. The buildup of radionuclide concentration in the soil from successive years of irrigation is taken into account. The radionuclide concentration in the soil and the dose is calculated using the following formula.

$$
D_{i, a(g d)}=C_{i, s(g)} \times L_{a(g)} \times U_{a} \times f_{y r(g)} \times D C_{i, a}
$$

where

$$
\begin{aligned}
& D_{i, a(g d)} \ldots . . . . . . . \text { annual TED to an individual from inhalation of radionuclide i from soil particulates } \\
& \text { suspended in the air (mrem/yr) (calculated value) } \\
& C_{i, s(g)} \ldots . . . . . . . . \text { concentration of radionuclide } i \text { in soil from irrigation of vegetable garden }(\mathrm{pCi} / \mathrm{kg}) \\
& \text { (see Section } 2.3 \text { for } C_{i, s(g)} \text { equation) (calculated value) }
\end{aligned}
$$

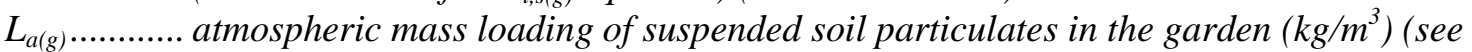

$$
\begin{aligned}
& \text { Table 5-12) } \\
& U_{a} \text {.............. age-adjusted inhalation rate }\left(\mathrm{m}^{3} / \mathrm{yr}\right) \text { (see Table 5-12) } \\
& f_{y r(g)} \text {............. fraction of year spent working in vegetable garden (unitless) (see Table 5-12) } \\
& D_{i, a} \text {.......... air inhalation dose coefficient for radionuclide i (mrem/pCi) (see Table 5-9) }
\end{aligned}
$$

\subsection{Direct Exposure to Garden Soil}

The exposure route for garden soil direct exposure assumes that the receptor receives direct exposure during time spent caring for a garden which has been irrigated with contaminated water. The irrigation 
water for the garden is assumed to be taken from a pond that is contaminated by seepage from the 680 sandstone layer. The buildup of radionuclide concentration in the soil from successive years of irrigation is taken into account. The radionuclide concentration in the soil and the dose is calculated using the following formula.

$$
\begin{aligned}
& D_{i, e(g)}=C_{i, s(g)} \times \rho_{s s} \times f_{y r(g)} \times D C_{i, e-15} \\
& \text { where } \\
& D_{i, e(g)} \text {.......... annual TED to an individual from external exposure to radionuclide } i \text { in } \\
& \text { contaminated garden soil (mrem/yr) (calculated value) } \\
& C_{i, s(g)} \ldots . . . . . . . \text { concentration of radionuclide } i \text { in soil from irrigation of vegetable garden }(\mathrm{pCi} / \mathrm{kg}) \\
& \text { ( } p C i / \mathrm{kg} \text { ) (see Section } 2.3 \text { for } C_{i, s(g)} \text { equation) (calculated value) }
\end{aligned}
$$

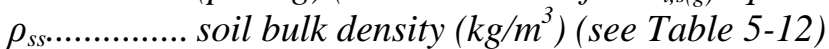

$$
\begin{aligned}
& f_{y r(g)} \text {............. fraction of year spent working in vegetable garden (unitless) (see Table 5-12) } \\
& D C_{i, e-15} \ldots . . . . . \text { dose coefficient for external exposure to } 15 \mathrm{~cm} \text { of soil uniformly contaminated with } \\
& \text { radionuclide i (depth of garden assumed to be } 15 \mathrm{~cm})\left(\mathrm{mrem} / \mathrm{yr} \text { per } \mathrm{pCi} / \mathrm{m}^{3}\right)(\mathrm{see} \\
& \text { Table 5-9) }
\end{aligned}
$$

\subsection{Portsmouth OSWDF GoldSim All-Pathways Dose Model}

\subsection{GoldSim Model Description}

The All-Pathways dose analysis was performed by implementing the dose equations described in Section 2.0 using the GoldSim ${ }^{\mathrm{TM}}$ software (specifically GoldSim ${ }^{\mathrm{TM}}$ Version $10.50 \mathrm{SP} 3$ (GTC 2010)). GoldSim ${ }^{\mathrm{TM}}$ is a widely used commercial software package that has been employed previously at SRNL to model onedimensional radionuclide transport and perform dose calculations (e.g. Smith, et al., 2009). GoldSim ${ }^{\mathrm{TM}}$ is a graphically based programming environment that allows a very modular approach to model construction. GoldSim $^{\mathrm{TM}}$ provides a structure where data tables, functions to perform numerical calculations, links to Excel spreadsheets, and plots of results, along with many other modeling features can be created. This section provides an overview of the All-Pathways dose GoldSim ${ }^{\mathrm{TM}}$ model.

Model features that would naturally go together can be grouped into containers which have the symbol:

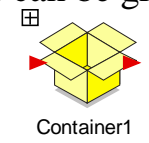

Figure 3-1 shows the contents of the top level container in the Portsmouth All-Pathways doses and limits model. Features of the All-Pathways model are explained by describing the function and contents of the more significant objects shown in this figure. 
SRNL-STI-2014-00130

Revision 0

\section{Portsmouth OSWDF All-Pathways Doses and Limits Analysis}

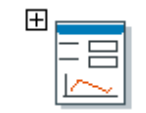

Model_Options

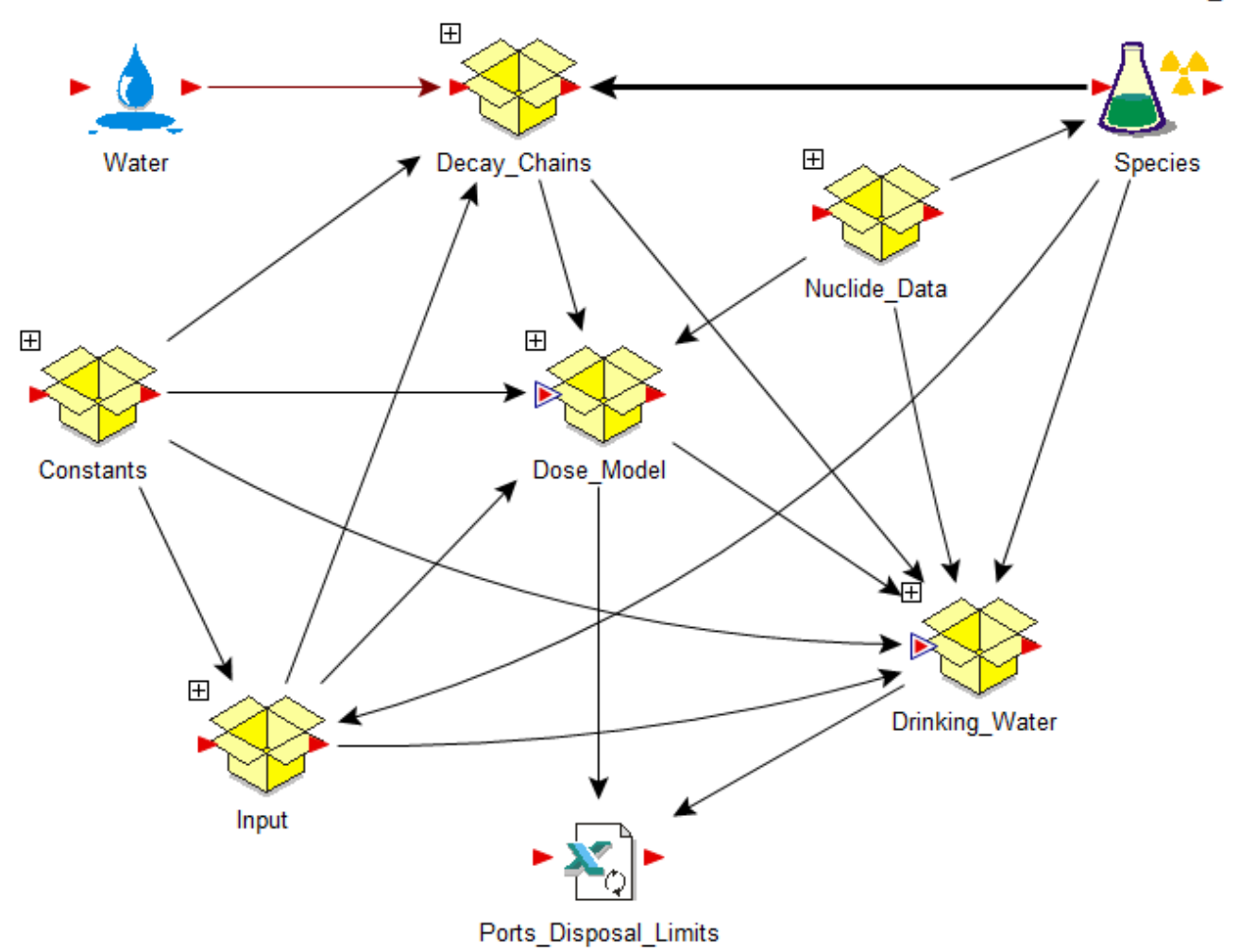

Export disposal limits for

Portsmouth parent nuclides

Figure 3-1. Contents of Upper Level Container in Goldsim Portsmouth All-Pathways Dose Model

The Water element is a reference liquid phase and the Species element contains basic physical data for the 61 radionuclides used in the model. These Species data include a unique name (e.g. Am241), the species molecular weight, half-life, and daughter radionuclides. The element Ports_Disposal_Limits provides a link to an Excel spreadsheet where results from the GoldSim model calculation of doses and disposal limits for parent radionuclides are collected. Disposal limits are calculated based on a maximum allowable dose of $25 \mathrm{mrem} / \mathrm{yr}$.

Container Nuclide_Data contains a data table of nuclide half-lives used to populate the Species element list and to calculated decay constants for the 61 radionuclides. The Constants container contains some useful modeling parameters such as days in a year, water density, and a large number used to avoid numerical problems from division by zero. The Drinking_Water container holds a calculation of disposal limits for radionuclides in the Portsmouth OSWDF that meet EPA drinking water standards. Because these calculations are not included as part of the Portsmouth limits and doses analysis they are not described further.

The remaining four upper-level model functions: Model_Options, and containers Input, Decay_Chains, and Dose_Model are described in greater detail below. 
The model element Model_Options is a dashboard where the user specifies five settings for the AllPathways modeling. As illustrated in Figure 3-2, each setting has two options one of which is displayed in the left-hand view with the alternative displayed in the right-hand view. Using the first four settings, the user specifies: 1) whether the conservative or reasonable OSWDF inventory is modeled, 2) whether base case or sensitivity dose coefficients are used, 3) the source of well water used for human ingestion and showering and 4) whether dose parameters for a typical (50 percentile) or representative (95 percentile) person are used.

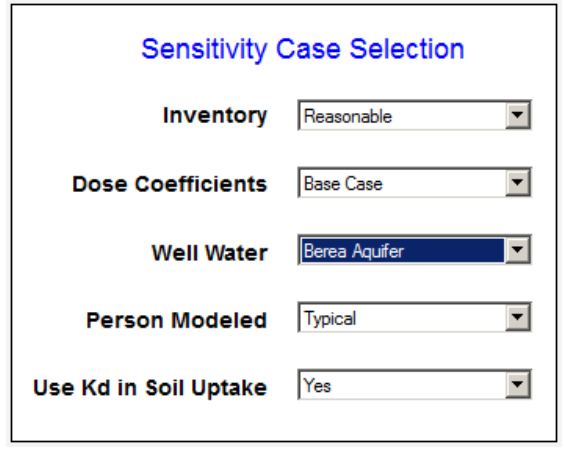

(a)

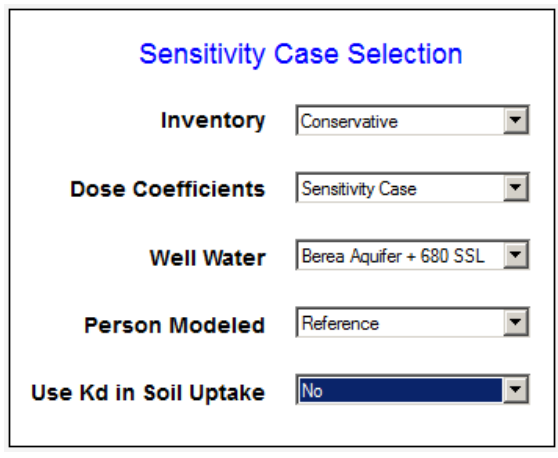

(b)

Figure 3-2. View of Model_Options Dashboard Showing User Options

The fifth model setting allows the user to apply a model of radionuclide uptake in garden soil that either includes radionuclide leaching from the soil using a simple $\mathrm{K}_{\mathrm{d}}$ approach or does not include this term. This setting is for model testing purposes only and final All-Pathways limits and dose calculations included the $K_{d}$ term when calculating soil uptake. Varying the other four settings allows the user to specify different analysis options. Table 6-1 shows the analyses performed for this study. The Inventory setting also includes a special Test option (not shown) that was used to test the model by making a calculation with dose parameters and coefficients used in the 2008 SRS E-Area Low Level Waste Disposal PA analyses.

Other elements in the top level container are additional containers used to collect related calculation data and calculations. The function of each of these containers is explained below.

Figure 3-3 shows an expanded view of the Input container. The function of this container is to obtain the correct input to run an All-Pathways scenario. STOMP output transients have been collected into a single Excel workbook. Five time series appear in Figure 3-3 as indicated by the icons across the bottom row such as:

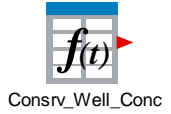

Each time series is linked to a spreadsheet in the Excel workbook that contains the transient STOMP data for surface water concentrations and well water concentrations for the reasonable and conservative inventory cases (Tables 4-3 through 4-9).

The structure in Figure 3-3 also illustrates the use of the modeling options selections. The selection chosen in dashboard box labeled Inventory in Figure 3-2 is passed to the data object Case shown in Figure 3-3. Similarly, the dashboard selection labeled Well Source in Figure 3-2 is passed to data object Well_Water. The value of Case is then used to select STOMP results for nuclide concentrations in the surface water and well water and the starting inventory for either the conservative or reasonable inventory 
cases. Similarly, the value of Well_Water is used to select whether the well water concentration is taken from the isolated Berea aquifer, selected in Figure 3-2(a), or from the Berea aquifer including some water from the 680 sandstone layer, selected in Figure 3-2(b).This method of selecting input ensures that the correct inventory is associated with the correct STOMP output once the Excel input file and worksheet names in the time series have been correctly matched.

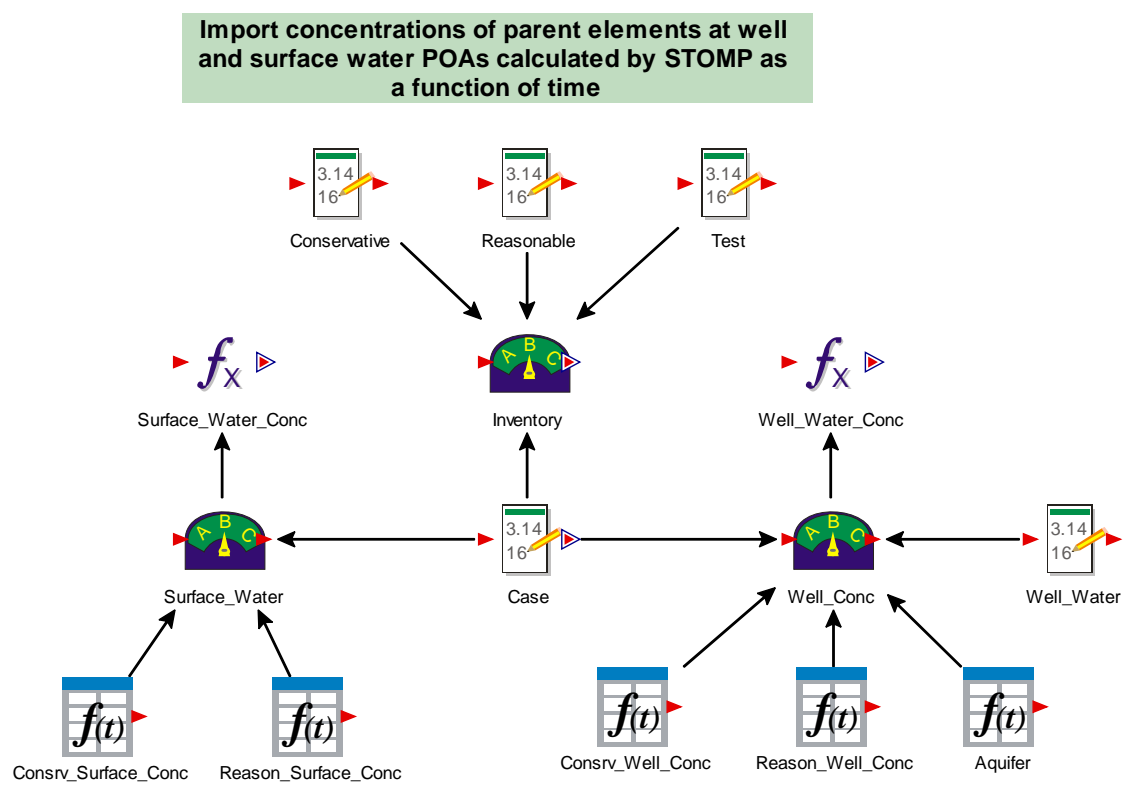

Figure 3-3. Expanded View of Input Container

Figure 3-4 shows an expanded view of the Decay_Chains container. For each parent nuclide, the inventory is added to a GoldSim Cell Pathway which is indicated by the symbol:

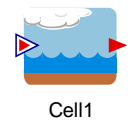

These cells are used to allow parent decay and the ingrowth of daughter radionuclides. Because the cells operate on a mass basis, the input inventory is converted from Curies to grams and the results are converted back to Curies outside the cell. Plots of the concentrations of decay chain species are made for each parent. Curies of the parent and daughter radionuclides are combined into the matrix function Parent_Curies for use in later calculations. Function Nuclides sums the Curies for each nuclide in the species list from all sources for plotting. The STOMP code used to calculate the transport of parent Portsmouth radionuclides accounts for parent decay but does not account for daughter ingrowth and daughter transport. Therefore, as the calculations in Decay_Chains imply, the All-Pathways doses and limits model accounts for daughters by calculating the Curies of each daughter produced by a parent nuclide at each time step and assuming that the daughter is transported to the POA along with the parent. At the POA, the dose contributions from each member of a parent radionuclide's decay chain are calculated and summed to give the total dose from the parent. This approach neglects differences in the transport between parent and daughter radionuclides and assumes that all daughters arrive at the point of assessment with the parent (11 radionuclides considered parents) based upon ingrowth alone. This is considered a realistic assumption for all daughters with half-lives less than one year (i.e. 40 of the 60 radionuclides), because within the slow flow transport, geologic environment of the OSWDF such shortlived daughters could not migrate very far from the parent. Secular equilibrium of the daughter with the 
parent is a typical assumption made for daughters with a half-life less than one year. Daughters with halflives greater than one year (i.e. only 14 of the 60 radionuclides) could potentially migrate either faster or slower than the parent depending upon the differences in $K_{d} S$, resulting in a different daughter concentration at the point of assessment for any point in time than based upon ingrowth alone. Such a consideration of $K_{d} S$ would most likely result in the peaks of the parents and daughters being separated in time resulting in a lower overall peak than would be calculated based upon ingrowth alone.

Twelve parent radionuclides (Am-241, Np-237, Pu-238, Pu-239, Tc-99, Th-228, Th-230, Th-232, U-234, U-235, U-236 and U-238) were included in the GoldSim model. However; initial inventories were specified for 19 radionuclides which include the 12 parents listed above and added Ac-228, Pa-233, Pa234m, Ra-224, Ra-228, Th-231 and Th-234. Preliminary calculations showed that the initial inventories of some of these radionuclides represented daughter ingrowth at equilibrium. Starting with no initial inventory for the daughter radionuclides, the inventories of Pa-233 as a daughter of Np-237, Pa-234m and Th-234 as daughters of U-238, and Th-231 as a daughter of U-235 reached their specified initial values within three years. Similarly, starting with no initial inventory for the daughter radionuclides, inventories of Ac-228, Ra-224, Ra-228 and Th-228 as daughters of Th-232 reached their specified initial values by 70 years and were within $0.5 \%$ of the specified initial values within 50 years. Therefore, to avoid double counting radioactive species, only the specified inventories for the 11 radionuclides (Am-241, Np-237, Pu-238, Pu-239, Tc-99, Th-230, Th-232, U-234, U-235, U-236 and U-238) were used in the doses and limits calculations.

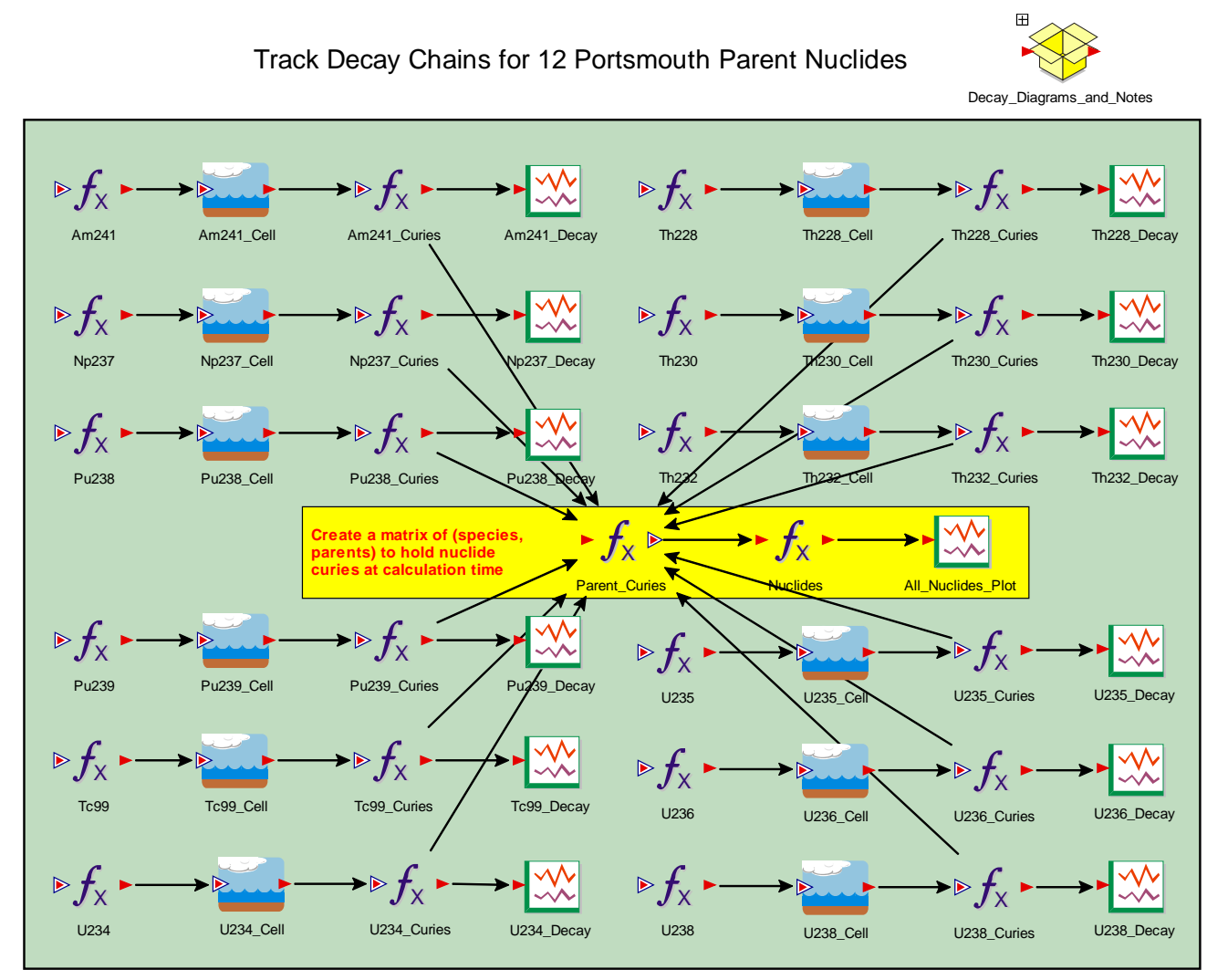

Figure 3-4. Expanded View of Decay_Chains Container

Figure 3-5 shows an expanded view of the Dose_Model container. This container simply holds seven other containers used to model separate parts of the dose and limits calculations. Each of these containers is briefly described below. 
SRNL-STI-2014-00130

Revision 0

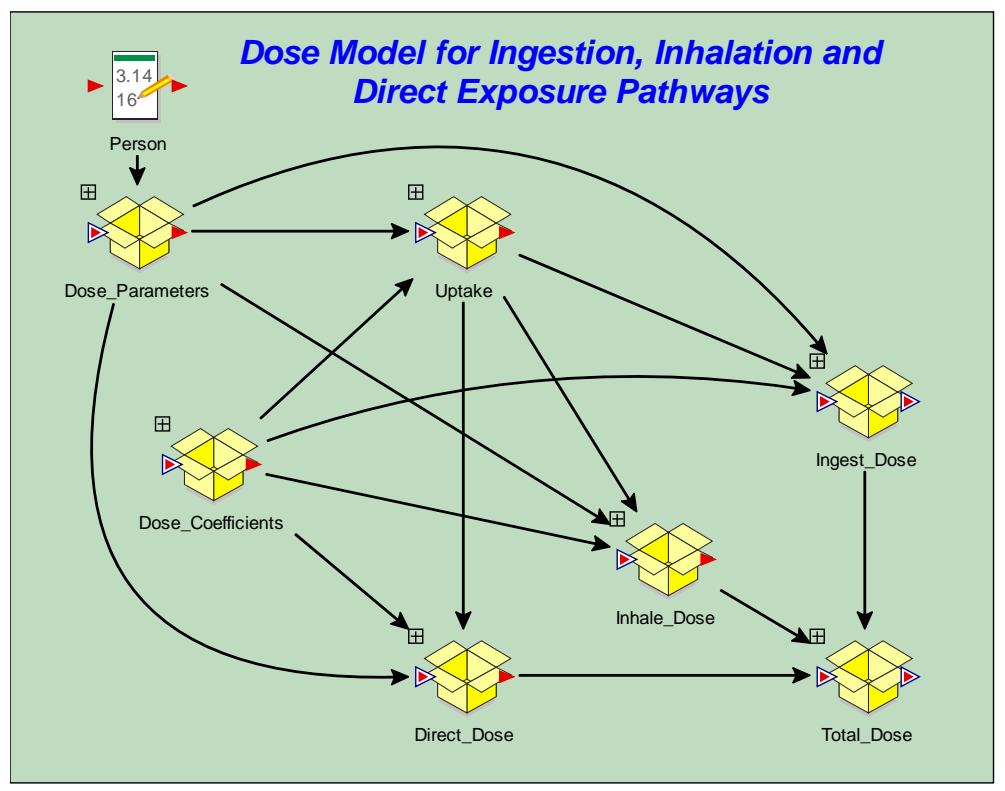

Figure 3-5. Expanded View of Dose_Model Container

As the expanded view of the Dose_Parameter container in Figure 3-6 shows, this container holds input data for the 54 parameters used in the dose model. Values of these parameters are listed in Table 5-12. 

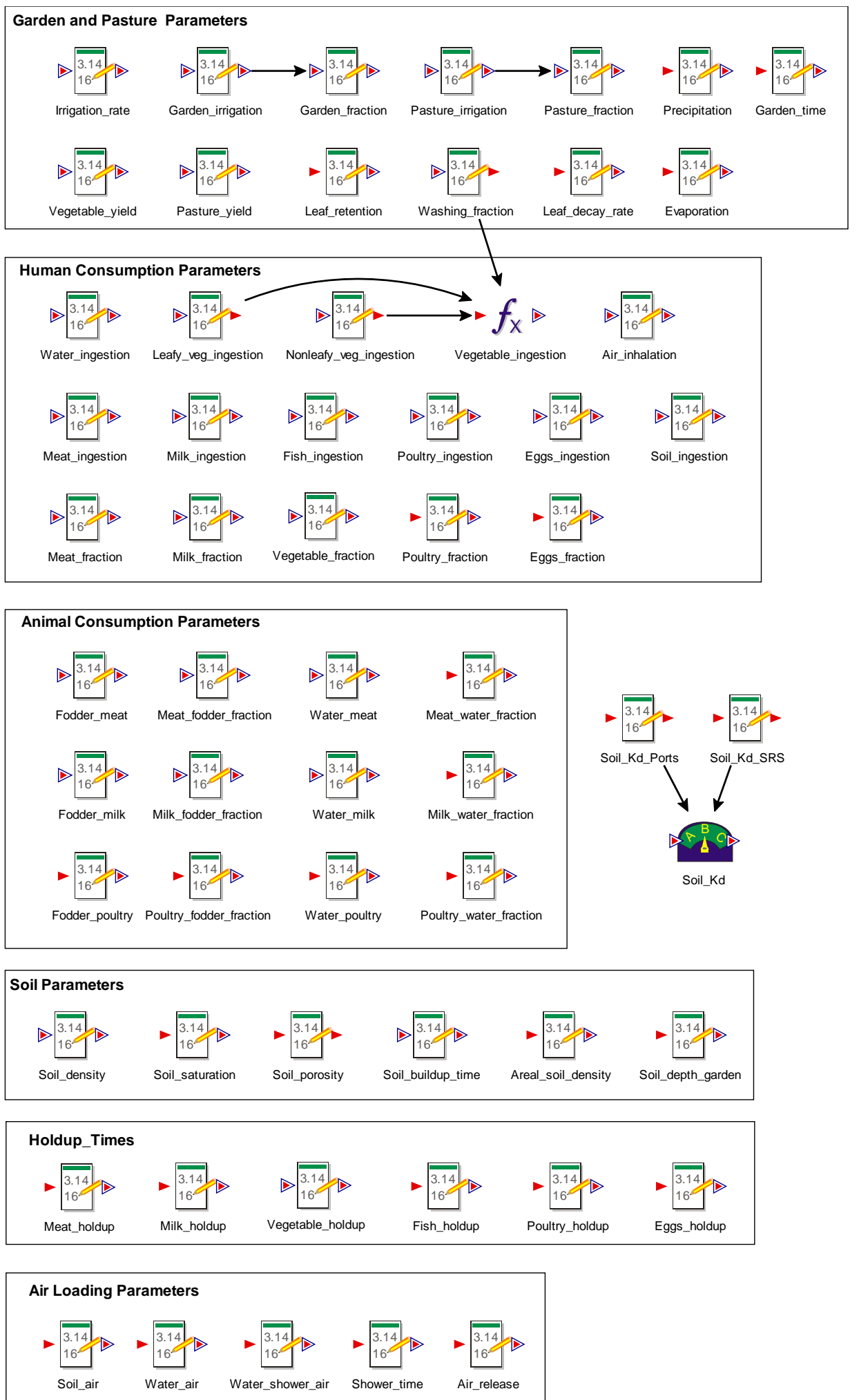

Figure 3-6. Expanded view of Dose_Parameters container

Figure 3-7 shows an expanded view of the Dose_Coefficients container. Here the term "dose coefficient" is used to include dose coefficients for ingestion of contaminated water and inhalation of contaminated air 
and transfer factors from fodder to meat, fodder to milk, fodder to poultry, fodder to eggs, and from soil to plant roots. The dose factor from external exposure to soil contaminated to a depth of $15 \mathrm{~cm}$, representing garden soil, is also included with the dose coefficients. While a transfer factor from contaminated water to fish is also tabulated, fish consumption is not included in the Portsmouth dose calculation.

Water ingestion and air inhalation dose conversion factors and dose coefficients for exposure to $15 \mathrm{~cm}$ of contaminated soil and for transfer from soil to plant roots were used in the previously reported Portsmouth Intruder Analysis (Smith and Phifer, 2013). More recent values for dose coefficients for exposure to $15 \mathrm{~cm}$ of contaminated soil and for transfer from soil to plant roots are available. Therefore, as shown in Figure 3-2, an option was included in the model that allows the user to apply either the coefficients used for the intruder analysis or the more recent dose coefficients in the All-Pathways dose calculation. Comparison of results from applying these two sets of dose coefficients (and dose parameters) is used as a sensitivity study.

For model testing and verification, the option to use SRS PA dose coefficients is also included. These coefficients are used in dose calculations when the Test option is selected in the Inventory box on the Model_Options dashboard. This option also sets some of the dose parameters to values used for SRS PA calculation. The test case uses an existing result from analysis of an SRS E-Area waste disposal unit to verify that the model is correctly calculating doses.

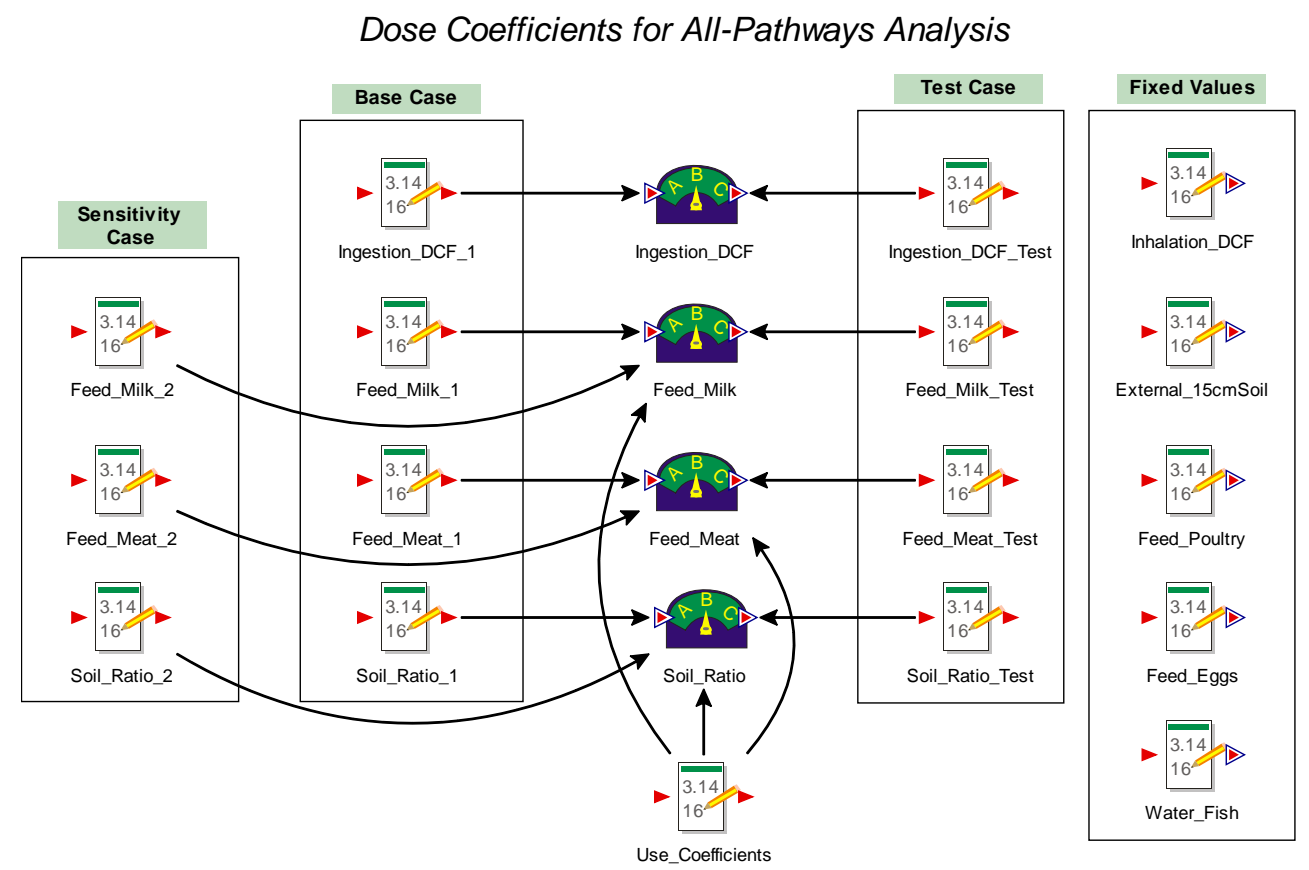

Figure 3-7. Expanded View of Dose_Coefficeints Container

For computational convenience the dose equations were broken up into two pieces. This made the model equations more readable which helped the checking process. The first part of each equation was termed the uptake factor which calculates the concentration of contamination in the material that is the direct source of human exposure. The contents of container Uptake where these calculations are made is shown in Figure 3-8. For example, the function Leaf_Uptake performs the calculation: 


$$
\text { Leaf_Uptake }_{i}=\frac{r f_{p} I}{Y_{v} \lambda_{e}}\left(1-e^{-\lambda_{e} t_{i r r}}\right)
$$

The Leaf_Uptake equals the liters of contaminated water retained per kilogram of leafy vegetables. Because the decay constant $\left(\lambda_{e}\right)$ is a function of both vegetable and radioactive decay, Leaf_Uptake is calculated for each radionuclide indicated by the subscript $i$. Total vegetable uptake is the sum of plant uptake through leaf and root:

$$
\text { Vegetable_Uptake }_{i}=\text { Leaf_Uptake }_{i}+\text { Root_Uptake }_{i}
$$

Uptake factors are used to calculate doses to a resident farmer in the following three containers.

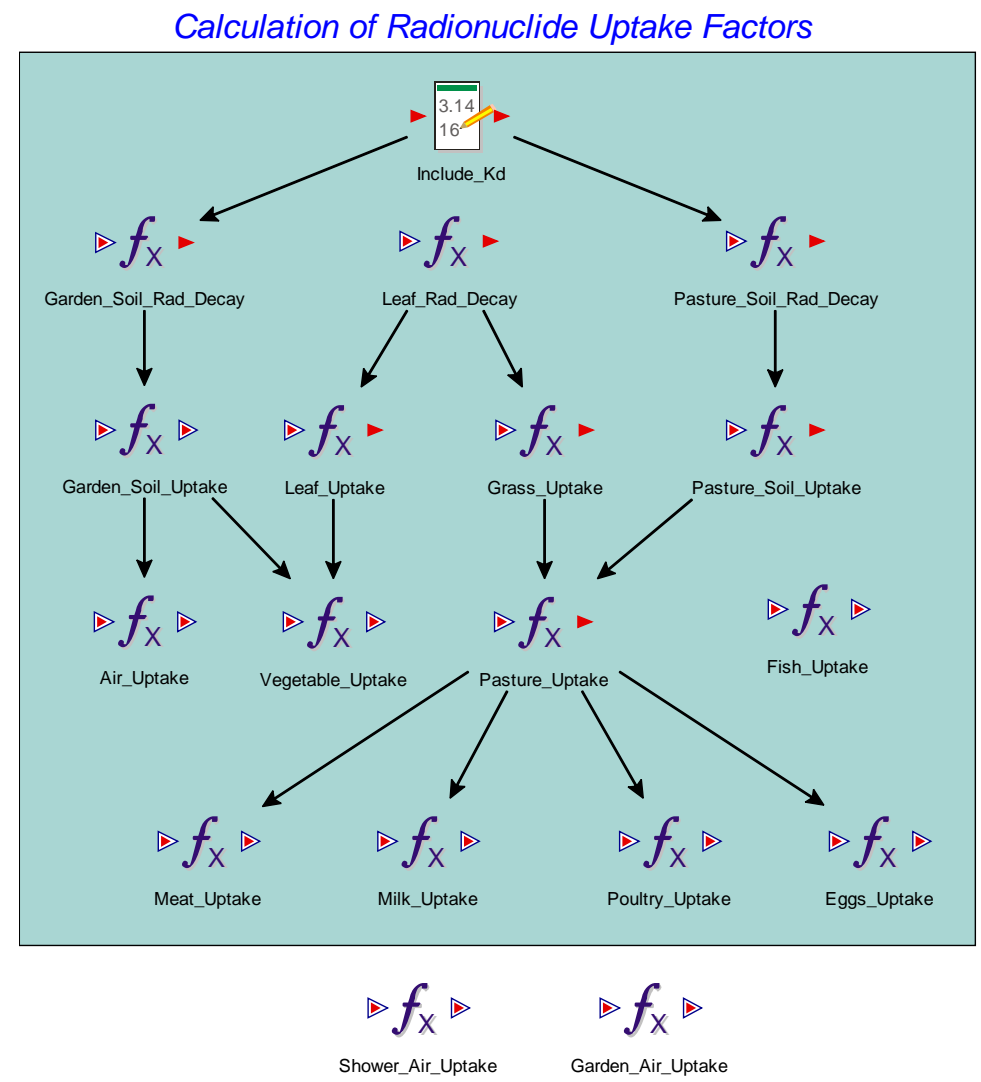

Figure 3-8. Expanded View of Uptake Container

An expanded view of container Ingest_Dose where doses to a resident farmer from the ingestion of contaminated food sources and soil are calculated is shown in Figure 3-9. In all cases, a dose conversion factor (DCF) for the ingestion pathway is first calculated by multiplying the source uptake factor by the dose coefficient for water ingestion and human usage factors. The resulting DCF's are then multiplied by the concentration of each parent nuclide and their daughters at the POA to calculate a pathway dose for each parent nuclide. This calculation makes use of the Parent_Curies matrix described above which keeps track of daughter products from each parent nuclide separately. The dose from each parent includes the dose from daughter radionuclides. A total pathway dose is calculated by summing over the 
parents and a total dose from each parent radionuclide is calculated by summing over the pathways. This method allows following the contribution to total equivalent dose from both pathway and parent nuclide.

As an example, DCF_Vegetable is calculated for each nuclide in the species list as:

$$
D C F_{-} V_{\text {Vegetable }}=\text { Vegetable_Uptake }_{i} D C_{i, w} U_{v} f_{v} e^{-\lambda_{i} t_{v}}
$$

The equivalent dose from ingestion of contaminated vegetables is then calculated for each parent nuclide as:

$$
\text { Vegetable_Dose }_{p}=\sum_{i=1}^{n} D_{C F} \text { Vegetable }_{i} C_{i, p, w}
$$


Calculation of Internal Doses from Ingestion Pathways

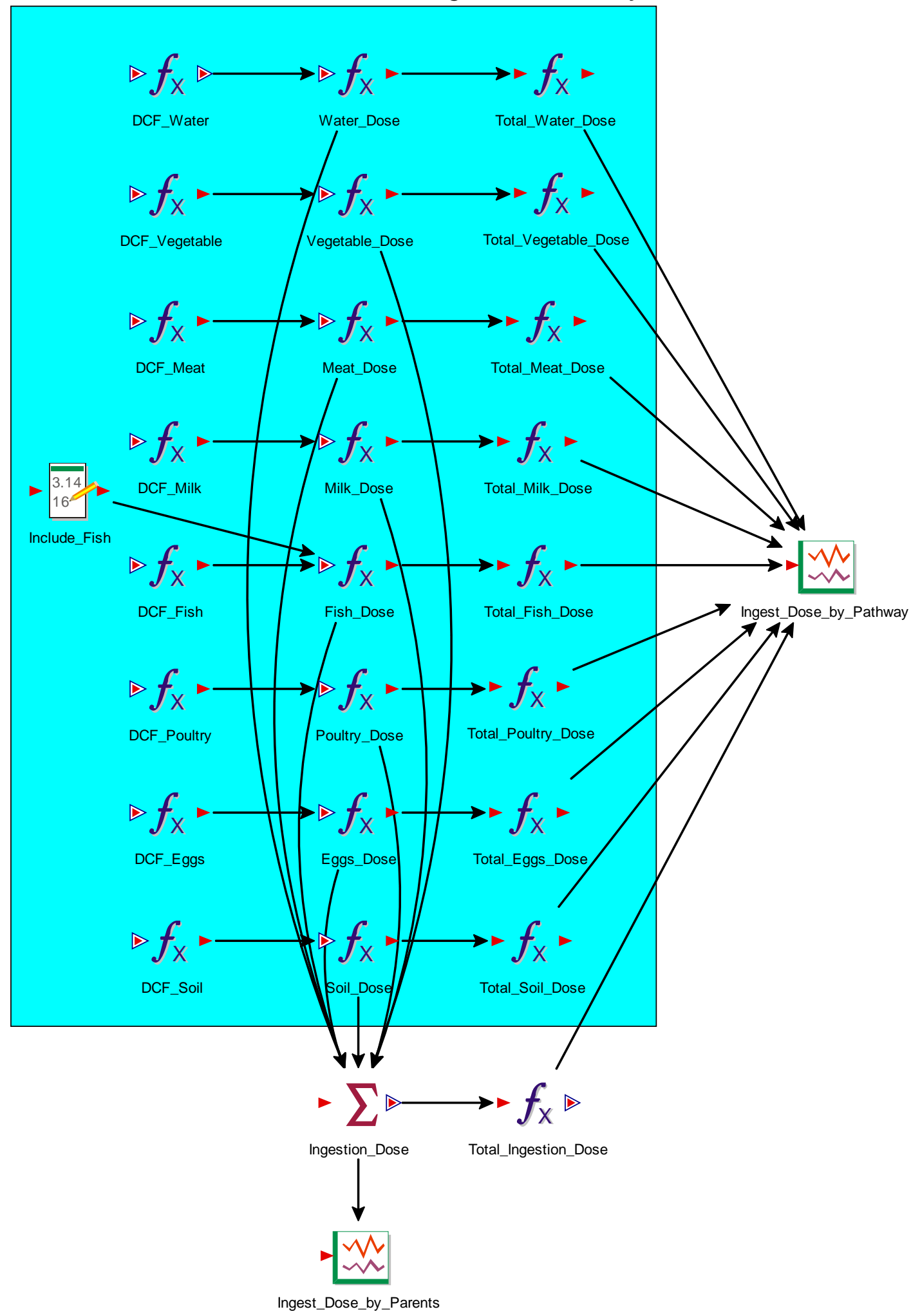

Figure 3-9. Expanded View of Ingest_Dose Container 
Equivalent doses from air inhalation and external exposure are calculated using an approach identical to that shown above for the calculation of ingestion dose. The inhalation dose has three pathways and the external exposure dose only one pathway as shown in Figure 3-10, which shows the contents of container Inhale_Dose, and Figure 3-11, which shows the contents of container Direct_Dose, respectively.

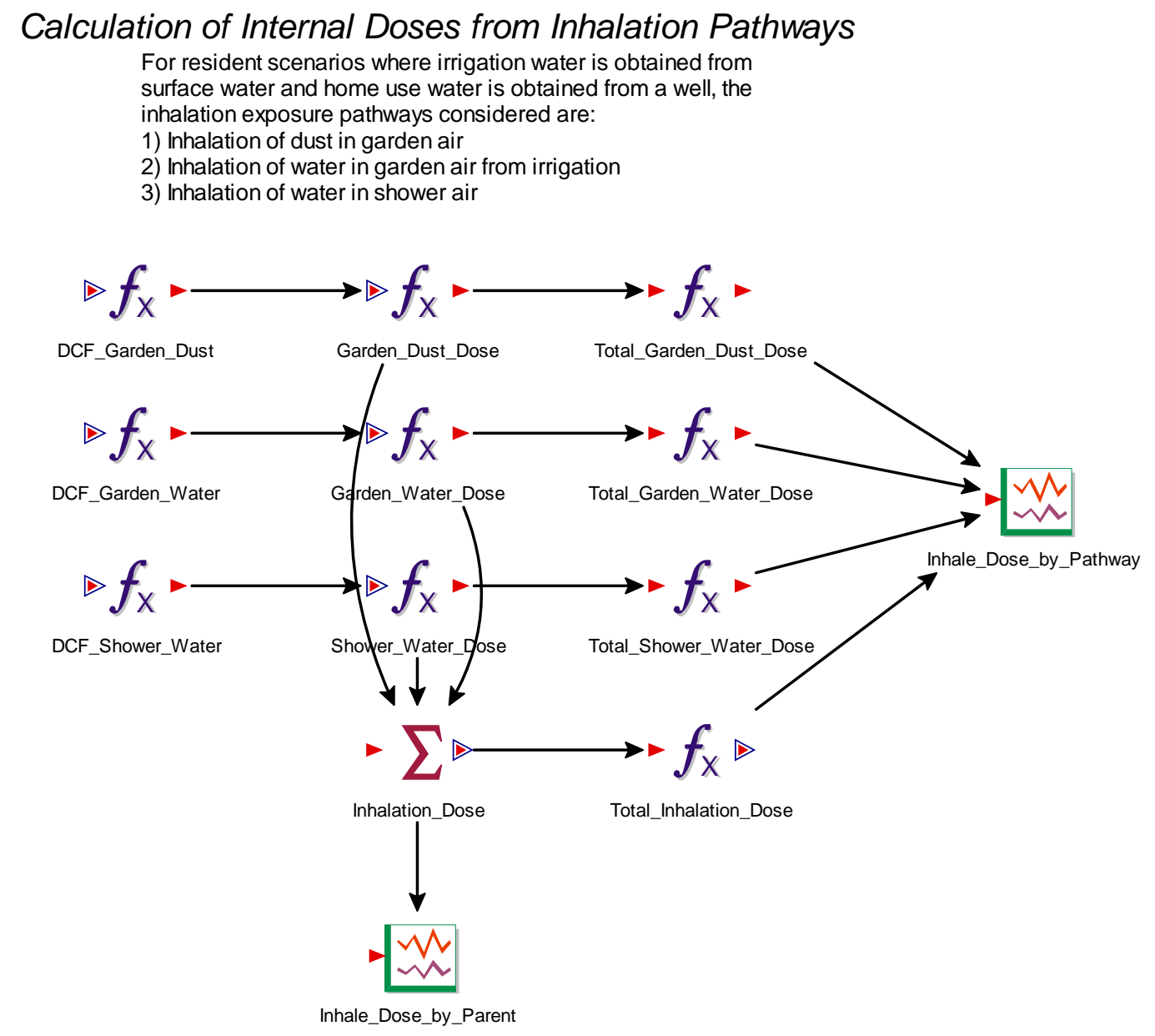

Figure 3-10. Expanded View of Inhale_Dose Container 
SRNL-STI-2014-00130

Revision 0

\section{Calculation of Dose from External Exposure Pathways}

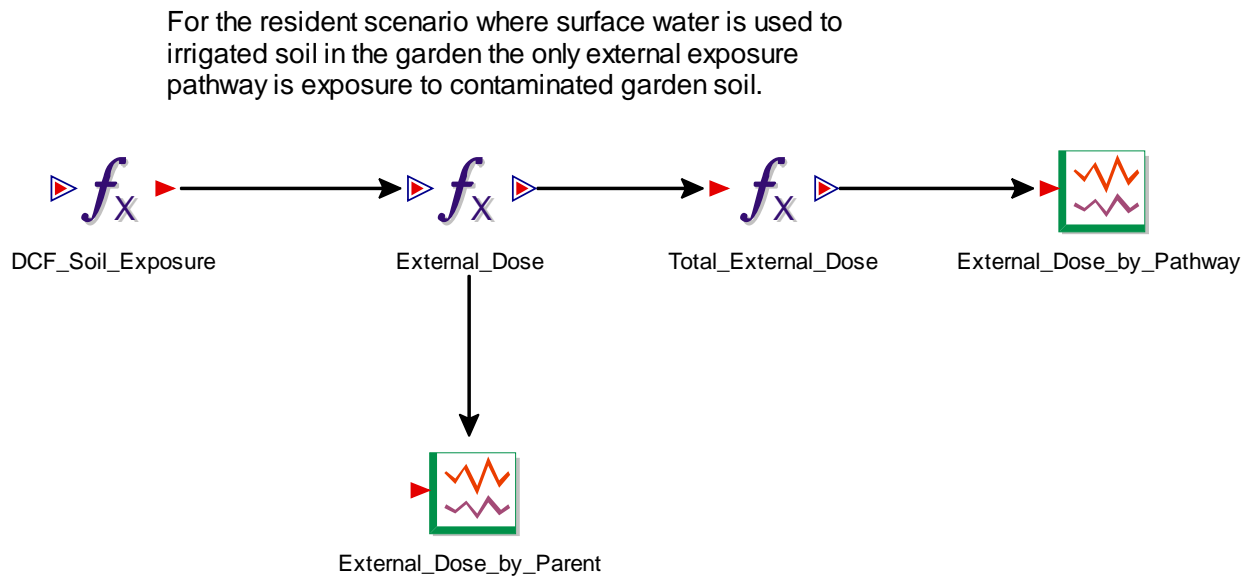

Figure 3-11. Expanded View of Direct_Dose Container

Finally, container Total_Dose, shown in Figure 3-12, is used to collect the results, show total dose from all pathways by parent nuclide and pathway type (ingestion, inhalation and external exposure). This container also compares calculated doses to the dose limit $(25 \mathrm{mrem} / \mathrm{yr})$ to determine disposal limits for individual parent radionuclides and for the proposed OSWDF waste mixture.

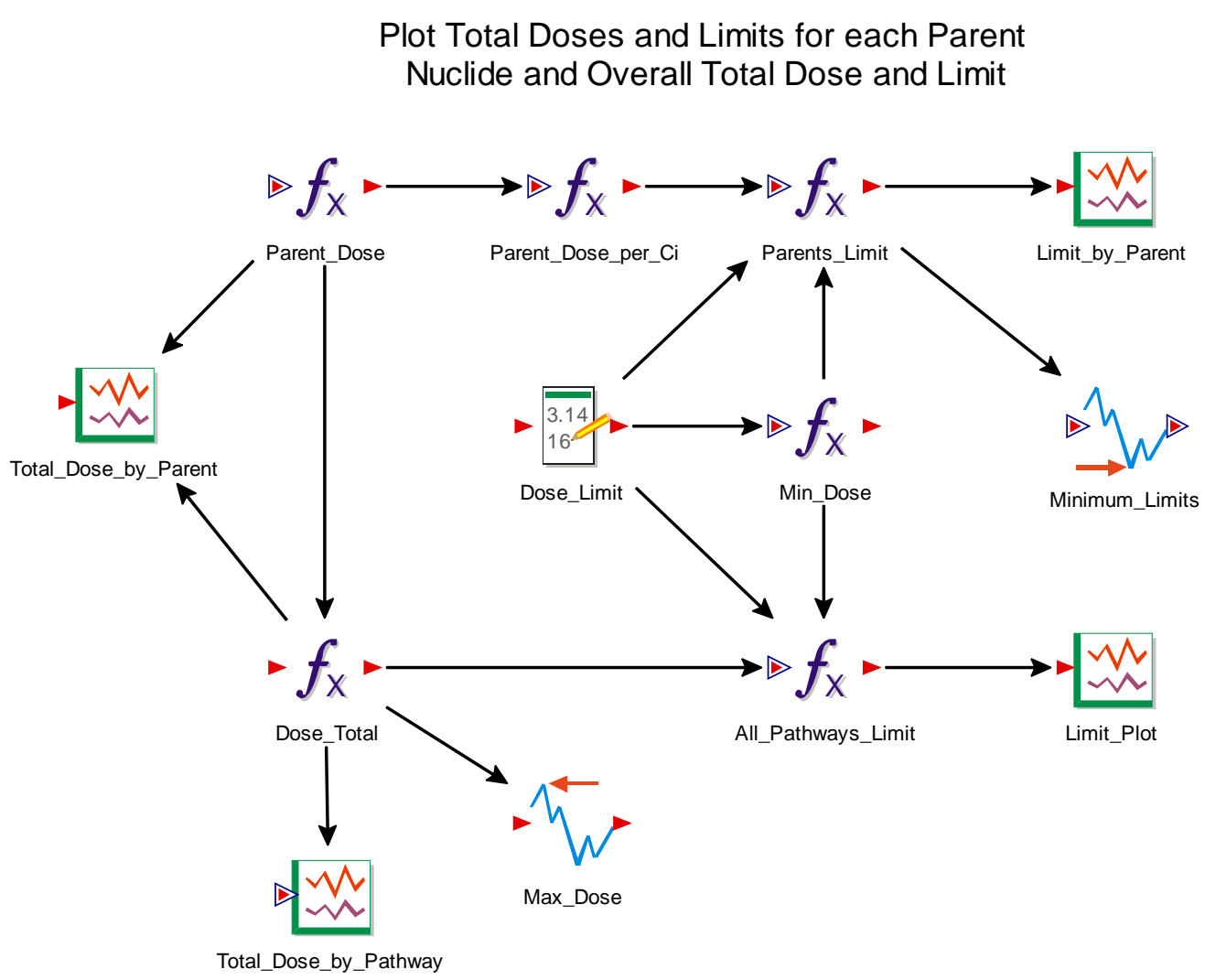

Figure 3-12. Expanded View of Total_Dose Container 


\subsection{Model Validation Testing}

Limited model validation testing was performed by running a dose and disposal limits calculation for the SRS West Slit Trench which is a low level waste disposal unit in the SRS E-Area. Dose parameters and dose coefficients consistent with those used in the 2008 E-Area PA (WSRC 2008) were entered into the model. Figure 3-7 shows that a set of test dose coefficients is available in the model. An inventory of one Curie was specified for each of the 12 parent radionuclides. The test case inventory, dose coefficients and dose parameters are selected by choosing the Test option for Inventory in the dashboard control shown in Figure 3-2.

The test was performed in terms of disposal limits. That is, from the nominal one Curie inventory the model calculates the Curies of each parent radionuclide that can be buried that will just meet the allpathways dose limit of $25 \mathrm{mrem} / \mathrm{yr}$. The validation exercise demonstrated that, as shown in Table 3-1, the model closely matched disposal limits calculated for the 2008 PA for Am-241, Np-237, Tc-99 and U-236. Disposal limits for the other parent radionuclides did not match because under transport conditions applicable at SRS, daughters from these radionuclides are largely responsible for doses within the first 1000 years of disposal.

Table 3-1. GoldSim Model Validation Test Results

\begin{tabular}{|c|c|c|}
\hline Nuclide & $\begin{array}{c}\text { SRS E-Area PA } \\
\text { Preliminary } \\
\text { Disposal Limit } \\
\text { (Ci) }\end{array}$ & $\begin{array}{c}\text { Disposal Limit Calculated } \\
\text { using Portsmouth } \\
\text { Goldsim Model } \\
\text { (Ci) }\end{array}$ \\
\hline Am-241 & $2.50 \mathrm{E}+01$ & $2.60 \mathrm{E}+01$ \\
\hline Np-237 & $4.23 \mathrm{E}-02$ & $4.23 \mathrm{E}-02$ \\
\hline Tc-99 & $1.37 \mathrm{E}+01$ & $1.37 \mathrm{E}+01$ \\
\hline $\mathbf{U}-236$ & $1.01 \mathrm{E}+09$ & $1.06 \mathrm{E}+09$ \\
\hline
\end{tabular}

The validation test results provided confidence that the basic dose equations are correctly implemented in the GoldSim model.

\subsection{Quality Assurance}

GoldSim has been used at the Savannah River Site for numerous applications over the past several years. A Software Quality Assurance Plan (SQAP) for GoldSim use at SRS was written (Swingle 2006) and has been applied for subsequent use of the software. Additionally both this report and the GoldSim model have undergone a technical design check process per SRNS 2012.

\subsection{Portsmouth OSWDF STOMP Model Input to All-Pathways Dose Model}

As described in FBP 2014b two computer models were used to analyze the fate and transport of radionuclides from the potential Portsmouth On-Site Waste Disposal Facility (OSWDF). The Hydrologic 
Evaluation of Landfill Performance (HELP) model (Schroeder et al. 1994) was used to evaluate the water budget for the OSWDF itself. The purpose of the HELP model was to calculate the infiltration rates to groundwater through the varying man-made layers of the OSWDF, including the cover (or cap), waste layer, and liner system. The water flux to the underlying media obtained as output from the HELP model was then utilized as input to a 3-dimensional Surface Transport Over Multiple Phases (STOMP) model (White and Oostrom 2000, 2006), which was used to predict water and contaminant movement at the OSWDF site in unsaturated, water-bearing, and small-area-scale groundwater zones to the Points of Assessment (POAs).

The OSWDF will sit on top of the Cuyahoga shale, which is underlain by Sunbury shale and Berea sandstone. A continuous 2-ft sandstone layer (i.e. 680-ft elevation sandstone layer (680 SSL)), occurs in the middle of the Cuyahoga shale that outcrops to the ground surface and is considered a potential migration pathway for the contaminants released from the OSWDF. However, while the 680 SSL does contain water at various locations, it is not an aquifer. The Berea sandstone is mostly saturated in the area and is considered to be the first groundwater aquifer unit and a potential migration pathway for the contaminants released from the OSWDF. The Berea sandstone is underlain by Bedford shale, a thick shale unit that is an aquitard for the area. Therefore, the STOMP model domain was set to include all the potential discharge locations and exposure points associated with the 680 SSL and Berea sandstone aquifer (FBP 2014a). Figure 4-1 shows the 3-D STOMP model domain, and Figure 4-2 shows a vertical representation of the model.

The STOMP model of flow and transport from the OSWDF to the POAs was used for the following cases:

- A base case reasonable inventory scenario (see Table 4-1),

- A sensitivity case \#1 conservative inventory scenario (see Table 4-1),

- A sensitivity case \#2 uncased well scenario, (this is not a separate STOMP calculation, this case used output from the base case and added $5 \%$ of the water at highest concentration in the $680 \mathrm{SS}$ layer to $95 \%$ clean water from the Berea aquifer to obtain a source of well water), and

- A sensitivity case \#3 low uranium source $\mathrm{K}_{\mathrm{d}}$ scenario.

The base case reasonable inventory scenario, which used maximum concentrations for contaminants in the waste streams and no barrier material in the waste streams, involved loading only cells 1 through 10 based upon the debris loading schedule and debris concentrations, which resulted in the highest concentration waste being in the lower numbered cells (see Figure 4-3). The lowest numbered cells are furthest from the 680 sandstone layer. The sensitivity Case \#1 conservative inventory scenario used maximum concentrations for contaminants in the waste streams and included barrier material in the waste streams. This scenario involved loading the 10 cells with a uniform inventory distribution (i.e. same waste concentrations in each cell) (see Figure 4-4) and adding an $11^{\text {th }}$ cell with an inventory equal to $1 / 10^{\text {th }}$ of the initial inventory. Therefore, all cells have the same inventory but the total inventory is $10 \%$ greater than in the base case. This scenario also places greater concentrations closer to the 680 sandstone layer. The POA-1 surface water zone (POA-1 SW zone) represents the area of the 680 SSL outcrop from which contaminated seepage is projected to occur by the STOMP model. The POA-3 groundwater (POA$3 \mathrm{GW}$ ) represents the location in the Berea sandstone above which the 680 SSL beyond the $100 \mathrm{~m}$ perimeter surrounding the OSWDF has the greatest concentration over time. This location moves over time as indicated by the tan arrows in Figures 4-3 and 4-4. The sensitivity Case \#2 uncased well scenario was a scenario requested by the Ohio Environmental Protection Agency (OEPA) for use in the Portsmouth Waste Disposition Remedial Investigation and Feasibility Study (WD RI/FS) Report (FBP 2014a). This scenario assumes that an uncased well to the Berea is placed at the location of the greatest concentration over time in the 680 SSL beyond the $100 \mathrm{~m}$ perimeter surrounding the OSWDF and allows 
leakage from the 680 SSL into the Berea from which it is pumped for domestic water usage. As noted above, this scenario does not require an independent STOMP run. This sensitivity case assumes that the water pumped from the Berea consists of 95\% Berea groundwater and 5\% leakage from the 680 SSL through the uncased well. The sensitivity Case \#3 low uranium source $\mathrm{K}_{\mathrm{d}}$ scenario uses a low uranium $\mathrm{K}_{\mathrm{d}}$ of $14.6 \mathrm{~mL} / \mathrm{g}$ in the waste zone rather than the base case $\mathrm{K}_{\mathrm{d}}$ of $365 \mathrm{~mL} / \mathrm{g}$. Table $4-2$ provides a listing of the tables that provide the output for the POA-1 SW zone and POA-3 GW from the Portsmouth OSWDF STOMP Model that was utilized as input to the All-Pathways dose model for each of the modeled cases. Additionally Table 4-10 provides the modeled discharge to the ground surface from the area of the 680 SSL outcrop from which contaminated seepage is projected to occur (i.e. POA-1 SW zone) (FBP 2014b).

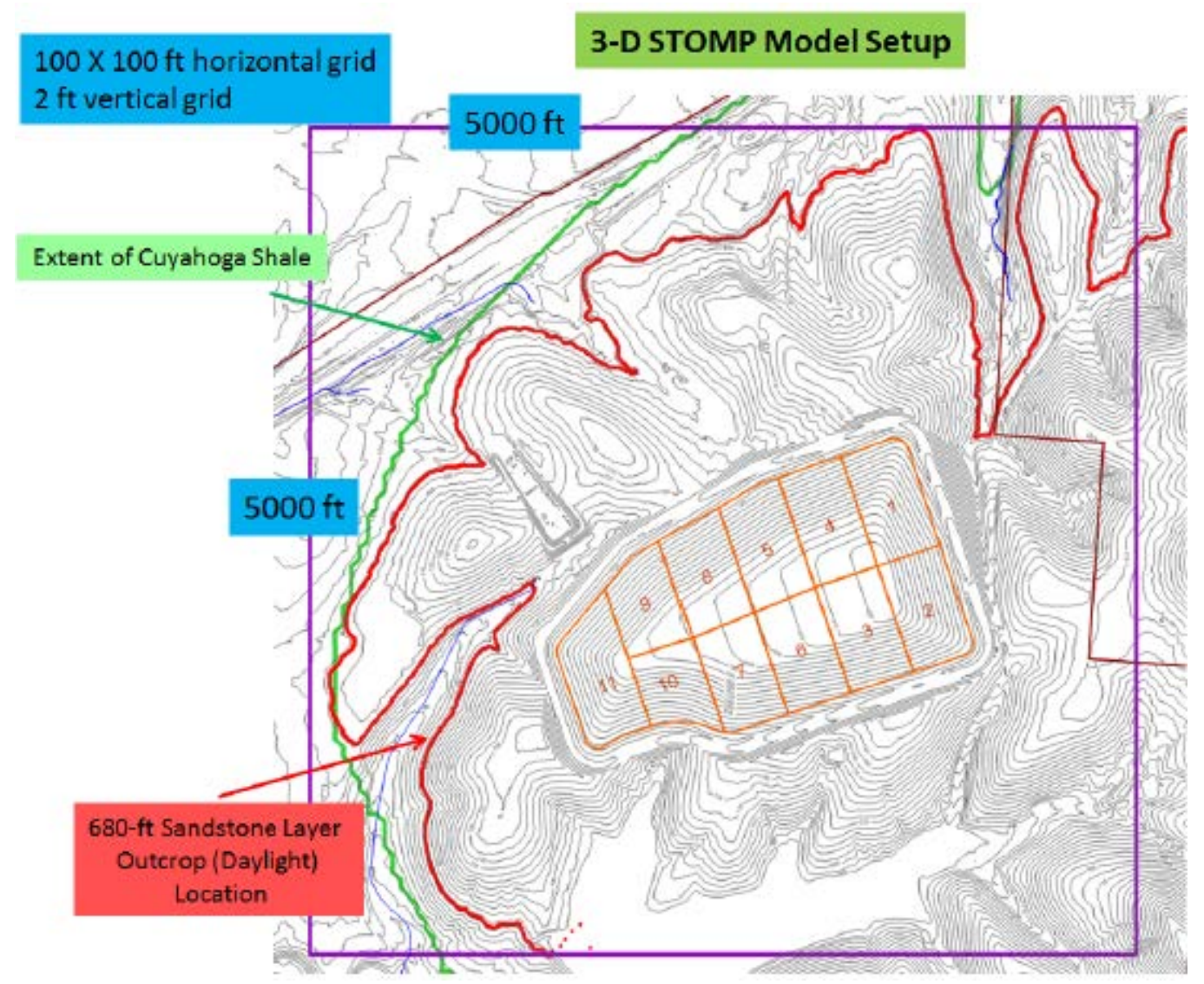

Figure 4-1. 3-D STOMP Model Domain (FBP 2014a) 


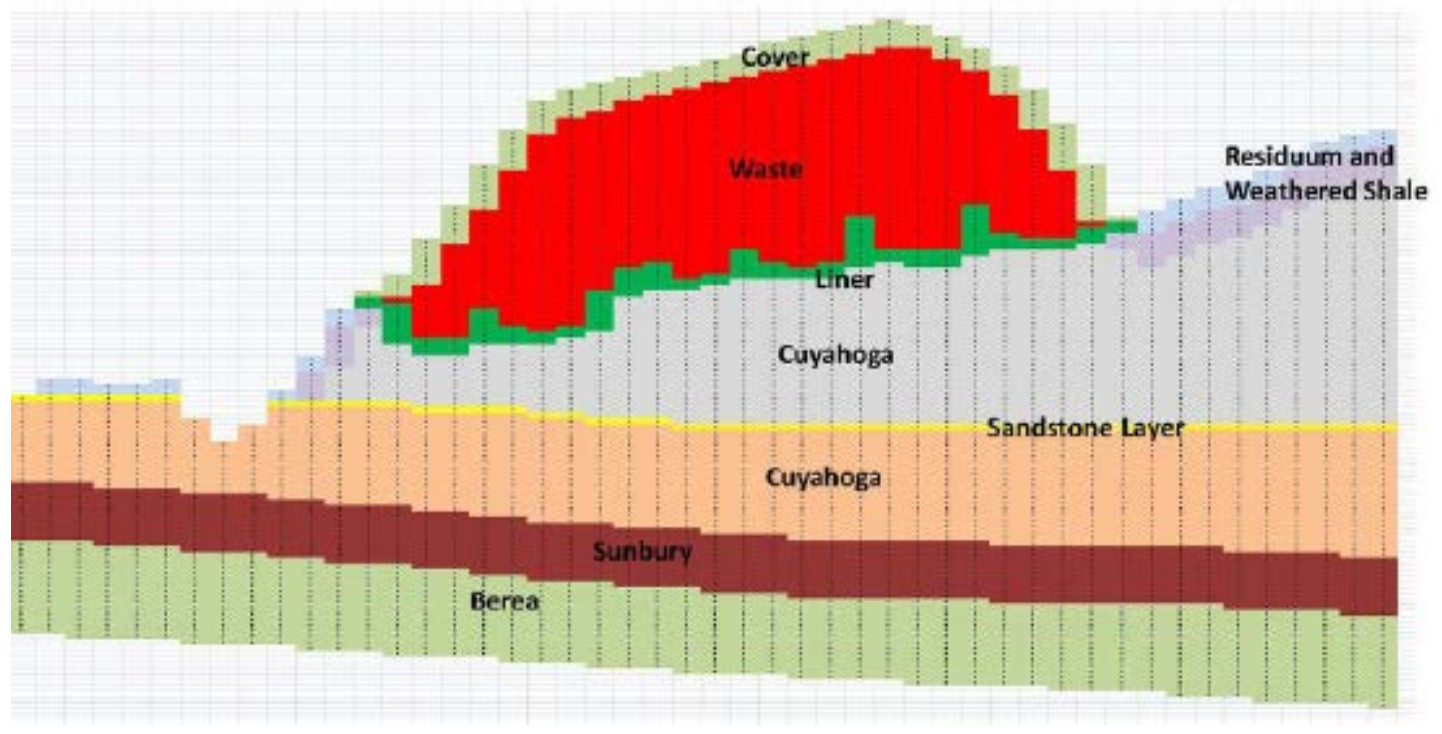

Figure 4-2. 3-D STOMP Model Vertical Representation (FBP 2014a)

Table 4-1. Portsmouth OSWDF Inventory Scenarios

\begin{tabular}{|c|c|c|}
\hline Nuclide & $\begin{array}{c}\text { Reasonable Case } \\
\text { Inventory } \\
\text { (Ci) }\end{array}$ & $\begin{array}{c}\text { Conservation Case } \\
\text { Inventory } \\
\text { (Ci) }\end{array}$ \\
\hline Tc-99 & $2.51 \mathrm{E}+02$ & $3.85 \mathrm{E}+02$ \\
\hline Th-230 & $4.98 \mathrm{E}-01$ & $6.03 \mathrm{E}-01$ \\
\hline Th-232 & $1.21 \mathrm{E}-02$ & $1.41 \mathrm{E}-02$ \\
\hline $\mathrm{U}-234$ & $1.54 \mathrm{E}+02$ & $1.88 \mathrm{E}+02$ \\
\hline $\mathrm{U}-235$ & $1.11 \mathrm{E}+01$ & $1.26 \mathrm{E}+01$ \\
\hline $\mathrm{U}-236$ & $1.50 \mathrm{E}+00$ & $1.74 \mathrm{E}+00$ \\
\hline $\mathrm{U}-238$ & $7.90 \mathrm{E}+01$ & $8.76 \mathrm{E}+01$ \\
\hline Np-237 & $1.23 \mathrm{E}-01$ & $1.48 \mathrm{E}-01$ \\
\hline Pu-238 & $1.04 \mathrm{E}-02$ & $1.16 \mathrm{E}-02$ \\
\hline Pu-239 & $2.75 \mathrm{E}-02$ & $2.92 \mathrm{E}-02$ \\
\hline Am-241 & $1.62 \mathrm{E}-02$ & $1.79 \mathrm{E}-02$ \\
\hline
\end{tabular}

Note to Table 4-1:

Reasonable case inventory from PAmodel-reasonablecase.xlsx and conservative case inventory from PAmodel-reasonablecase.xlsx (Abitz 2014). 


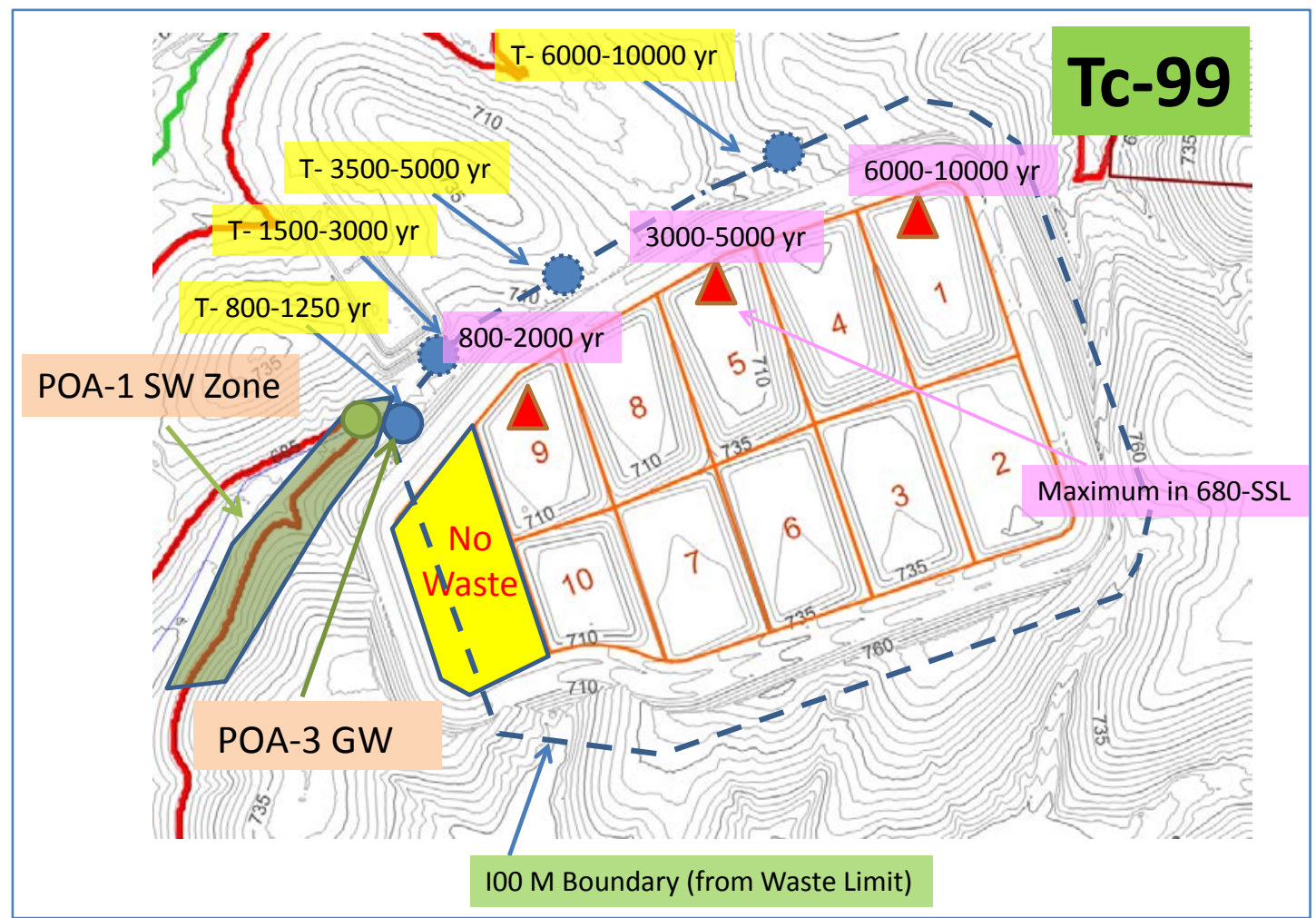

Figure 4-3. Reasonable Inventory Case Loading and POA Locations

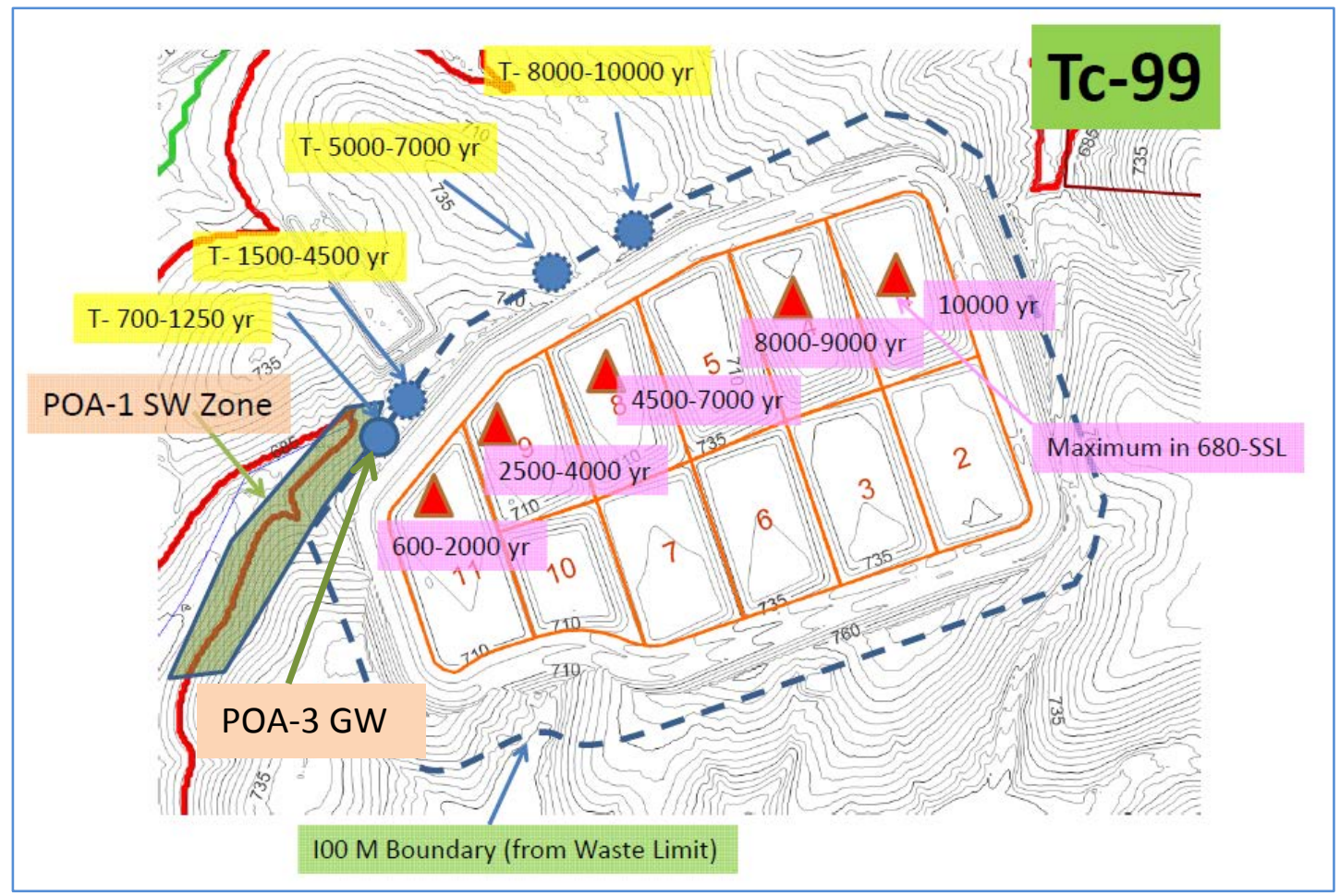

Figure 4-4. Conservative Inventory Case Loading and POA Locations 
SRNL-STI-2014-00130

Revision 0

Table 4-2. Portsmouth OSWDF STOMP Model Input to All-Pathways Dose Model

\begin{tabular}{|l|c|c|}
\hline \multirow{2}{*}{ Case } & \multicolumn{2}{c|}{ All-Pathways Dose Model Input } \\
\cline { 2 - 3 } & POA-1 SW Zone & POA-3 GW \\
\hline Base case reasonable inventory scenario & Table 4-3 & Table 4-4 \\
\hline Sensitivity case \#1 conservative inventory scenario & Table 4-5 & Table 4-6 \\
\hline Sensitivity case \#2 uncased well scenario & Table 4-3 & Table 4-7 \\
\hline Sensitivity case \#3 low uranium source $\mathrm{K}_{\mathrm{d}}$ scenario & Table 4-8 & Table 4-9 \\
\hline
\end{tabular}


Table 4-3. POA-1 SW Zone Base Case

\begin{tabular}{|c|c|c|c|c|c|c|c|c|c|c|c|}
\hline \multirow{2}{*}{$\begin{array}{c}\text { Time } \\
\text { (year) }\end{array}$} & \multicolumn{11}{|c|}{ Activity Concentration $(\rho \mathrm{Ci} / \mathrm{L})$} \\
\hline & Tc-99 & U-234 & U-235 & U-236 & U-238 & Am-241 & Np-237 & Pu-238 & Pu-239 & Th-228 & Th-230 \\
\hline 0 & $1.00 \mathrm{E}-18$ & $1.00 \mathrm{E}-18$ & $1.00 \mathrm{E}-18$ & $1.00 \mathrm{E}-18$ & $1.00 \mathrm{E}-18$ & $1.00 \mathrm{E}-18$ & 1.00E-18 & $1.00 \mathrm{E}-18$ & $1.00 \mathrm{E}-18$ & $1.00 \mathrm{E}-18$ & $1.00 \mathrm{E}-18$ \\
\hline 500 & $1.00 \mathrm{E}-18$ & $1.00 \mathrm{E}-18$ & $1.00 \mathrm{E}-18$ & $1.00 \mathrm{E}-18$ & $1.00 \mathrm{E}-18$ & $1.00 \mathrm{E}-18$ & $1.00 \mathrm{E}-18$ & $1.00 \mathrm{E}-18$ & $1.00 \mathrm{E}-18$ & $1.00 \mathrm{E}-18$ & $1.00 \mathrm{E}-18$ \\
\hline 600 & 1.00E-18 & $1.00 \mathrm{E}-18$ & $1.00 \mathrm{E}-18$ & $1.00 \mathrm{E}-18$ & $1.00 \mathrm{E}-18$ & $1.00 \mathrm{E}-18$ & $1.00 \mathrm{E}-18$ & $1.00 \mathrm{E}-18$ & $1.00 \mathrm{E}-18$ & $1.00 \mathrm{E}-18$ & $1.00 \mathrm{E}-18$ \\
\hline 700 & $1.00 \mathrm{E}-18$ & $1.00 \mathrm{E}-18$ & $1.00 \mathrm{E}-18$ & $1.00 \mathrm{E}-18$ & $1.00 \mathrm{E}-18$ & $1.00 \mathrm{E}-18$ & $1.00 \mathrm{E}-18$ & $1.00 \mathrm{E}-18$ & $1.00 \mathrm{E}-18$ & $1.00 \mathrm{E}-18$ & $1.00 \mathrm{E}-18$ \\
\hline 800 & $1.00 \mathrm{E}-18$ & $1.00 \mathrm{E}-18$ & $1.00 \mathrm{E}-18$ & $1.00 \mathrm{E}-18$ & & & & & & & \\
\hline 900 & & & & & & & & & & & \\
\hline 1000 & 7.87E-11 & $1.00 \mathrm{E}-18$ & $1.00 \mathrm{E}-18$ & $1.00 \mathrm{E}-18$ & $1.00 \mathrm{E}-18$ & $1.00 \mathrm{E}-18$ & $1.00 \mathrm{E}-18$ & $1.00 \mathrm{E}-18$ & $1.00 \mathrm{E}-18$ & $1.00 \mathrm{E}-18$ & $1.00 \mathrm{E}-18$ \\
\hline 1250 & 4.16E-07 & $1.00 \mathrm{E}-18$ & $1.00 \mathrm{E}-18$ & $1.00 \mathrm{E}-18$ & $1.00 \mathrm{E}-18$ & $1.00 \mathrm{E}-18$ & $1.00 \mathrm{E}-18$ & $1.00 \mathrm{E}-18$ & $1.00 \mathrm{E}-18$ & $1.00 \mathrm{E}-18$ & $1.00 \mathrm{E}-18$ \\
\hline 1500 & & & & & & & & & & & \\
\hline 2000 & & & & & & & & & & & \\
\hline 2500 & $2.40 \mathrm{E}+00$ & $1.24 \mathrm{E}-08$ & $8.98 \mathrm{E}-10$ & $1.21 \mathrm{E}-10$ & $6.40 \mathrm{E}-09$ & $1.00 \mathrm{E}-18$ & $1.00 \mathrm{E}-18$ & $1.00 \mathrm{E}-18$ & $1.00 \mathrm{E}-18$ & $1.00 \mathrm{E}-18$ & $1.00 \mathrm{E}-18$ \\
\hline 3000 & $6.30 \mathrm{E}+00$ & 5.69E-07 & $4.12 \mathrm{E}-08$ & 5.54E-09 & 2.94E-07 & $1.00 \mathrm{E}-18$ & $1.00 \mathrm{E}-18$ & $1.00 \mathrm{E}-18$ & $1.00 \mathrm{E}-18$ & $1.00 \mathrm{E}-18$ & $1.00 \mathrm{E}-18$ \\
\hline 3500 & $9.46 \mathrm{E}+00$ & 5.65E-06 & $5.22 \mathrm{E}-07$ & $5.50 \mathrm{E}-08$ & 3.74E-06 & $1.00 \mathrm{E}-18$ & $1.00 \mathrm{E}-18$ & $1.00 \mathrm{E}-18$ & $1.00 \mathrm{E}-18$ & $1.00 \mathrm{E}-18$ & $1.00 \mathrm{E}-18$ \\
\hline 4000 & $1.06 \mathrm{E}+01$ & & & & & & & & & & \\
\hline 4500 & $1.01 \mathrm{E}+01$ & $1.44 \mathrm{E}-04$ & $1.05 \mathrm{E}-05$ & $1.41 \mathrm{E}-06$ & 7.53E-05 & $1.00 \mathrm{E}-18$ & $1.00 \mathrm{E}-18$ & $1.00 \mathrm{E}-18$ & $1.00 \mathrm{E}-18$ & $1.00 \mathrm{E}-18$ & $1.00 \mathrm{E}-18$ \\
\hline 5000 & $8.77 \mathrm{E}+00$ & $3.46 \mathrm{E}-04$ & $2.52 \mathrm{E}-05$ & $3.41 \mathrm{E}-06$ & $1.81 \mathrm{E}-04$ & $1.00 \mathrm{E}-18$ & $1.00 \mathrm{E}-18$ & $1.00 \mathrm{E}-18$ & $1.00 \mathrm{E}-18$ & $1.00 \mathrm{E}-18$ & $1.00 \mathrm{E}-18$ \\
\hline 6000 & $6.48 \mathrm{E}+00$ & 1.19E-03 & 8.66E-05 & 1.17E-05 & $6.22 \mathrm{E}-04$ & $1.00 \mathrm{E}-18$ & & $1.00 \mathrm{E}-18$ & $1.00 \mathrm{E}-18$ & $1.00 \mathrm{E}-18$ & $1.00 \mathrm{E}-18$ \\
\hline 7000 & $5.51 \mathrm{E}+00$ & $2.66 \mathrm{E}-03$ & $1.94 \mathrm{E}-04$ & 2.63E-05 & 1.39E-03 & $1.00 \mathrm{E}-18$ & $1.00 \mathrm{E}-18$ & $1.00 \mathrm{E}-18$ & $1.00 \mathrm{E}-18$ & $1.00 \mathrm{E}-18$ & $1.00 \mathrm{E}-18$ \\
\hline 8000 & $4.95 E+00$ & 4.69E-03 & $3.44 \mathrm{E}-04$ & 4.64E-05 & 2.46E-03 & $1.00 \mathrm{E}-18$ & $1.00 \mathrm{E}-18$ & $1.00 \mathrm{E}-18$ & $1.00 \mathrm{E}-18$ & $1.00 \mathrm{E}-18$ & $1.00 \mathrm{E}-18$ \\
\hline 9000 & $4.38 \mathrm{E}+00$ & 7.04E-03 & $5.20 \mathrm{E}-04$ & $6.98 \mathrm{E}-05$ & 3.72E-03 & $1.00 \mathrm{E}-18$ & $1.00 \mathrm{E}-18$ & $1.00 \mathrm{E}-18$ & $1.00 \mathrm{E}-18$ & $1.00 \mathrm{E}-18$ & $1.00 \mathrm{E}-18$ \\
\hline 10000 & $3.72 E+00$ & 9.37E-03 & 6.89E-04 & 9.33E-05 & 4.96E-03 & $1.00 \mathrm{E}-18$ & $1.00 \mathrm{E}-18$ & $1.00 \mathrm{E}-18$ & $1.00 \mathrm{E}-18$ & $1.00 \mathrm{E}-18$ & $1.00 \mathrm{E}-18$ \\
\hline
\end{tabular}

Notes to Table 4-3:

- Reasonable case inventory and $\mathrm{U}$ source $\mathrm{K}_{\mathrm{d}}=365 \mathrm{~mL} / \mathrm{g}$.

- Average concentration at seep along the West Ditch with no surface water mixing.

- $1.00 \mathrm{E}-18$ represents a zero value. 
Table 4-4. POA-3 GW Base Case

\begin{tabular}{|c|c|c|c|c|c|c|c|c|c|c|c|}
\hline \multirow{2}{*}{$\begin{array}{c}\text { Time } \\
\text { (year) }\end{array}$} & \multicolumn{11}{|c|}{ Activity Concentration $(\rho \mathrm{Ci} / \mathrm{L})$} \\
\hline & Tc-99 & U-234 & U-235 & U-236 & U-238 & Am-241 & Np-237 & Pu-238 & Pu-239 & Th-228 & Th-230 \\
\hline 0 & $1.00 \mathrm{E}-18$ & $1.00 \mathrm{E}-18$ & $1.00 \mathrm{E}-18$ & $1.00 \mathrm{E}-18$ & $1.00 \mathrm{E}-18$ & $1.00 \mathrm{E}-18$ & $1.00 \mathrm{E}-18$ & $1.00 \mathrm{E}-18$ & $1.00 \mathrm{E}-18$ & $1.00 \mathrm{E}-18$ & $1.00 \mathrm{E}-18$ \\
\hline 500 & $.00 \mathrm{E}-18$ & $.00 \mathrm{E}-18$ & $1.00 \mathrm{E}-18$ & $1.00 \mathrm{E}-18$ & $1.00 \mathrm{E}-18$ & $1.00 \mathrm{E}-18$ & $1.00 \mathrm{E}-18$ & $1.00 \mathrm{E}-18$ & $1.00 \mathrm{E}-18$ & $1.00 \mathrm{E}-18$ & $1.00 \mathrm{E}-18$ \\
\hline 600 & $.00 \mathrm{E}-18$ & $1.00 \mathrm{E}-18$ & $1.00 \mathrm{E}-18$ & $1.00 \mathrm{E}-18$ & $.00 \mathrm{E}-18$ & $.00 \mathrm{E}-18$ & $.00 \mathrm{E}-18$ & 1.00E-18 & $1.00 \mathrm{E}-18$ & $1.00 \mathrm{E}-18$ & $1.00 \mathrm{E}-18$ \\
\hline 700 & $1.00 \mathrm{E}-18$ & $1.00 \mathrm{E}-18$ & $1.00 \mathrm{E}-18$ & $1.00 \mathrm{E}-18$ & $1.00 \mathrm{E}-18$ & $1.00 \mathrm{E}-18$ & $1.00 \mathrm{E}-18$ & $1.00 \mathrm{E}-18$ & $1.00 \mathrm{E}-18$ & $1.00 \mathrm{E}-18$ & $1.00 \mathrm{E}-18$ \\
\hline 800 & $.00 \mathrm{E}-18$ & $1.00 \mathrm{E}-18$ & $1.00 \mathrm{E}-18$ & $1.00 \mathrm{E}-18$ & $1.00 \mathrm{E}-18$ & $1.00 \mathrm{E}-18$ & $1.00 \mathrm{E}-18$ & 1.00E-18 & $1.00 \mathrm{E}-18$ & $1.00 \mathrm{E}-18$ & $1.00 \mathrm{E}-18$ \\
\hline 900 & $1.00 \mathrm{E}-18$ & $1.00 \mathrm{E}-18$ & $1.00 \mathrm{E}-18$ & $1.00 \mathrm{E}-18$ & $1.00 \mathrm{E}-18$ & $1.00 \mathrm{E}-18$ & $1.00 \mathrm{E}-18$ & 1.00E-18 & $1.00 \mathrm{E}-18$ & $1.00 \mathrm{E}-18$ & $1.00 \mathrm{E}-18$ \\
\hline 1000 & $1.00 \mathrm{E}-18$ & $1.00 \mathrm{E}-18$ & $1.00 \mathrm{E}-18$ & $1.00 \mathrm{E}-18$ & $1.00 \mathrm{E}-18$ & $1.00 \mathrm{E}-18$ & $1.00 \mathrm{E}-18$ & $1.00 \mathrm{E}-18$ & $1.00 \mathrm{E}-18$ & $1.00 \mathrm{E}-18$ & $1.00 \mathrm{E}-18$ \\
\hline 1250 & $1.00 \mathrm{E}-18$ & $1.00 \mathrm{E}-18$ & $1.00 \mathrm{E}-18$ & $1.00 \mathrm{E}-18$ & $1.00 \mathrm{E}-18$ & $1.00 \mathrm{E}-18$ & $1.00 \mathrm{E}-18$ & 1.00E-18 & $1.00 \mathrm{E}-18$ & $1.00 \mathrm{E}-18$ & $1.00 \mathrm{E}-18$ \\
\hline 1500 & $1.00 \mathrm{E}-18$ & $1.00 \mathrm{E}-18$ & $1.00 \mathrm{E}-18$ & $1.00 \mathrm{E}-18$ & $1.00 \mathrm{E}-18$ & & $1.00 \mathrm{E}-18$ & $1.00 \mathrm{E}-18$ & 1.00 & $1.00 \mathrm{E}-18$ & $1.00 \mathrm{E}-18$ \\
\hline 2000 & & & & & & & & & & & \\
\hline 2500 & $1.00 \mathrm{E}-18$ & $1.00 \mathrm{E}-18$ & $1.00 \mathrm{E}-18$ & $1.00 \mathrm{E}-18$ & $1.00 \mathrm{E}-18$ & $1.00 \mathrm{E}-18$ & $1.00 \mathrm{E}-18$ & $1.00 \mathrm{E}-18$ & $1.00 \mathrm{E}-18$ & $1.00 \mathrm{E}-18$ & $1.00 \mathrm{E}-18$ \\
\hline 3000 & $1.00 \mathrm{E}-18$ & $1.00 \mathrm{E}-18$ & $1.00 \mathrm{E}-18$ & $1.00 \mathrm{E}-18$ & $1.00 \mathrm{E}-18$ & $1.00 \mathrm{E}-18$ & $1.00 \mathrm{E}-18$ & 1.00E-18 & $1.00 \mathrm{E}-18$ & $1.00 \mathrm{E}-18$ & $1.00 \mathrm{E}-18$ \\
\hline 3500 & $1.00 \mathrm{E}-18$ & $1.00 \mathrm{E}-18$ & $1.00 \mathrm{E}-18$ & $1.00 \mathrm{E}-18$ & $1.00 \mathrm{E}-18$ & $1.00 \mathrm{E}-18$ & $1.00 \mathrm{E}-18$ & $1.00 \mathrm{E}-18$ & $1.00 \mathrm{E}-18$ & $1.00 \mathrm{E}-18$ & $1.00 \mathrm{E}-18$ \\
\hline 4000 & $1.00 \mathrm{E}-18$ & $1.00 \mathrm{E}-18$ & $1.00 \mathrm{E}-18$ & $1.00 \mathrm{E}-18$ & & & & $1.00 \mathrm{E}-18$ & & $1.00 \mathrm{E}-18$ & $1.00 \mathrm{E}-18$ \\
\hline 4500 & $1.00 \mathrm{E}-18$ & $1.00 \mathrm{E}-18$ & $1.00 \mathrm{E}-18$ & $1.00 \mathrm{E}-18$ & $1.00 \mathrm{E}-18$ & $1.00 \mathrm{E}-18$ & $1.00 \mathrm{E}-18$ & $1.00 \mathrm{E}-18$ & $1.00 \mathrm{E}-18$ & $1.00 \mathrm{E}-18$ & $1.00 \mathrm{E}-18$ \\
\hline 5000 & $1.00 \mathrm{E}-18$ & $1.00 \mathrm{E}-18$ & $1.00 \mathrm{E}-18$ & $1.00 \mathrm{E}-18$ & $1.00 \mathrm{E}-18$ & $1.00 \mathrm{E}-18$ & $1.00 \mathrm{E}-18$ & $1.00 \mathrm{E}-18$ & $1.00 \mathrm{E}-18$ & $1.00 \mathrm{E}-18$ & $1.00 \mathrm{E}-18$ \\
\hline 6000 & $1.00 \mathrm{E}-18$ & $1.00 \mathrm{E}-18$ & $1.00 \mathrm{E}-18$ & $1.00 \mathrm{E}-18$ & $1.00 \mathrm{E}-18$ & $1.00 \mathrm{E}-18$ & $1.00 \mathrm{E}-18$ & $1.00 \mathrm{E}-18$ & $1.00 \mathrm{E}-18$ & $1.00 \mathrm{E}-18$ & $1.00 \mathrm{E}-18$ \\
\hline 7000 & $1.00 \mathrm{E}-18$ & $1.00 \mathrm{E}-18$ & $1.00 \mathrm{E}-18$ & $1.00 \mathrm{E}-18$ & $1.00 \mathrm{E}-18$ & $1.00 \mathrm{E}-18$ & $1.00 \mathrm{E}-18$ & 1.00E-18 & $1.00 \mathrm{E}-18$ & $1.00 \mathrm{E}-18$ & $1.00 \mathrm{E}-18$ \\
\hline 8000 & $1.00 \mathrm{E}-18$ & $1.00 \mathrm{E}-18$ & $1.00 \mathrm{E}-18$ & $1.00 \mathrm{E}-18$ & $1.00 \mathrm{E}-18$ & $1.00 \mathrm{E}-18$ & $1.00 \mathrm{E}-18$ & $1.00 \mathrm{E}-18$ & $1.00 \mathrm{E}-18$ & $1.00 \mathrm{E}-18$ & $1.00 \mathrm{E}-18$ \\
\hline 9000 & $1.00 \mathrm{E}-18$ & $1.00 \mathrm{E}-18$ & $1.00 \mathrm{E}-18$ & $1.00 \mathrm{E}-18$ & $1.00 \mathrm{E}-18$ & $1.00 \mathrm{E}-18$ & $1.00 \mathrm{E}-18$ & $1.00 \mathrm{E}-18$ & $1.00 \mathrm{E}-18$ & $1.00 \mathrm{E}-18$ & $1.00 \mathrm{E}-18$ \\
\hline 10000 & $1.00 \mathrm{E}-18$ & $1.00 \mathrm{E}-18$ & $1.00 \mathrm{E}-18$ & $1.00 \mathrm{E}-18$ & $1.00 \mathrm{E}-18$ & $1.00 \mathrm{E}-18$ & $1.00 \mathrm{E}-18$ & $1.00 \mathrm{E}-18$ & $1.00 \mathrm{E}-18$ & $1.00 \mathrm{E}-18$ & $1.00 \mathrm{E}-18$ \\
\hline
\end{tabular}

Notes to Table 4-4:

- Groundwater well in Berea aquifer.

- Reasonable case inventory, $100 \%$ Berea groundwater, and U source $K_{d}=365$ mL/g.

- $1.00 \mathrm{E}-18$ represents a zero value. 
Table 4-5. POA-1 SW Zone Sensitivity Case \#1

\begin{tabular}{|c|c|c|c|c|c|c|c|c|c|c|c|}
\hline \multirow{2}{*}{$\begin{array}{c}\text { Time } \\
\text { (year) }\end{array}$} & \multicolumn{11}{|c|}{ Activity Concentration $(\rho \mathrm{Ci} / \mathrm{L})$} \\
\hline & Tc-99 & U-234 & U-235 & U-236 & U-238 & Am-241 & Np-237 & Pu-238 & Pu-239 & Th-228 & Th-230 \\
\hline 0 & 1.00E-18 & $1.00 \mathrm{E}-18$ & $1.00 \mathrm{E}-18$ & $1.00 \mathrm{E}-18$ & $1.00 \mathrm{E}-18$ & $1.00 \mathrm{E}-18$ & $1.00 \mathrm{E}-18$ & $1.00 \mathrm{E}-18$ & $1.00 \mathrm{E}-18$ & $1.00 \mathrm{E}-18$ & $1.00 \mathrm{E}-18$ \\
\hline 500 & $1.00 \mathrm{E}-18$ & $1.00 \mathrm{E}-18$ & $1.00 \mathrm{E}-18$ & $1.00 \mathrm{E}-18$ & $1.00 \mathrm{E}-18$ & $1.00 \mathrm{E}-18$ & $1.00 \mathrm{E}-18$ & $1.00 \mathrm{E}-18$ & $1.00 \mathrm{E}-18$ & $1.00 \mathrm{E}-18$ & $1.00 \mathrm{E}-18$ \\
\hline 600 & 1.00E-18 & 1.00E-18 & 1.00E-18 & 1.00E-18 & 1.00E-18 & $1.00 \mathrm{E}-18$ & 1.00E-18 & $1.00 \mathrm{E}-18$ & $1.00 \mathrm{E}-18$ & 1.00E-18 & $1.00 \mathrm{E}-18$ \\
\hline 700 & $1.00 \mathrm{E}-18$ & $1.00 \mathrm{E}-18$ & $1.00 \mathrm{E}-18$ & $1.00 \mathrm{E}-18$ & $1.00 \mathrm{E}-18$ & $1.00 \mathrm{E}-18$ & $1.00 \mathrm{E}-18$ & $1.00 \mathrm{E}-18$ & $1.00 \mathrm{E}-18$ & $1.00 \mathrm{E}-18$ & $1.00 \mathrm{E}-18$ \\
\hline 800 & $1.08 \mathrm{E}-10$ & $1.00 \mathrm{E}-18$ & $1.00 \mathrm{E}-18$ & $1.00 \mathrm{E}-18$ & $1.00 \mathrm{E}-18$ & $1.00 \mathrm{E}-18$ & $1.00 \mathrm{E}-18$ & $1.00 \mathrm{E}-18$ & $1.00 \mathrm{E}-18$ & $1.00 \mathrm{E}-18$ & $1.00 \mathrm{E}-18$ \\
\hline 900 & 2.23E-08 & $1.00 \mathrm{E}-18$ & $1.00 \mathrm{E}-18$ & 1.00E-18 & 1.00E-18 & $1.00 \mathrm{E}-18$ & $1.00 \mathrm{E}-18$ & $1.00 \mathrm{E}-18$ & $1.00 \mathrm{E}-18$ & 1.00E-18 & $1.00 \mathrm{E}-18$ \\
\hline 1000 & 7.84E-07 & $1.00 \mathrm{E}-18$ & $1.00 \mathrm{E}-18$ & $1.00 \mathrm{E}-18$ & $1.00 \mathrm{E}-18$ & $1.00 \mathrm{E}-18$ & $1.00 \mathrm{E}-18$ & $1.00 \mathrm{E}-18$ & $1.00 \mathrm{E}-18$ & $1.00 \mathrm{E}-18$ & $1.00 \mathrm{E}-18$ \\
\hline 1250 & 2.13E-03 & $1.00 \mathrm{E}-18$ & $1.81 \mathrm{E}-16$ & $1.00 \mathrm{E}-18$ & 4.64E-15 & $1.00 \mathrm{E}-18$ & $1.00 \mathrm{E}-18$ & $1.00 \mathrm{E}-18$ & $1.00 \mathrm{E}-18$ & 1.00E-18 & $1.00 \mathrm{E}-18$ \\
\hline 1500 & 3.07E-01 & 5.93E-12 & 4.93E-13 & 5.49E-14 & $3.42 \mathrm{E}-12$ & $1.00 \mathrm{E}-18$ & $1.00 \mathrm{E}-18$ & $1.00 \mathrm{E}-18$ & $1.00 \mathrm{E}-18$ & 1.00E-18 & $1.00 \mathrm{E}-18$ \\
\hline 2000 & $4.65 \mathrm{E}+01$ & 9.09E-08 & 6.15E-09 & 8.43E-10 & $4.26 \mathrm{E}-08$ & & $1.00 \mathrm{E}-18$ & $1.00 \mathrm{E}-18$ & $1.00 \mathrm{E}-18$ & $1.00 \mathrm{E}-18$ & $1.00 \mathrm{E}-18$ \\
\hline 2500 & $1.91 \mathrm{E}+02$ & 2.22E-05 & 1.50E-06 & $2.06 \mathrm{E}-07$ & 1.03E-05 & $1.00 \mathrm{E}-18$ & $1.00 \mathrm{E}-18$ & $1.00 \mathrm{E}-18$ & $1.00 \mathrm{E}-18$ & $1.00 \mathrm{E}-18$ & $1.00 \mathrm{E}-18$ \\
\hline 3000 & $2.62 \mathrm{E}+02$ & $6.41 \mathrm{E}-04$ & 4.35E-05 & 5.97E-06 & 3.01E-04 & $1.00 \mathrm{E}-18$ & $1.00 \mathrm{E}-18$ & $1.00 \mathrm{E}-18$ & $1.00 \mathrm{E}-18$ & 1.00E-18 & $1.00 \mathrm{E}-18$ \\
\hline 3500 & $2.89 \mathrm{E}+02$ & $5.60 \mathrm{E}-03$ & 3.81E-04 & 5.23E-05 & $2.64 \mathrm{E}-03$ & $1.00 \mathrm{E}-18$ & $1.00 \mathrm{E}-18$ & $1.00 \mathrm{E}-18$ & $1.00 \mathrm{E}-18$ & $1.00 \mathrm{E}-18$ & $1.00 \mathrm{E}-18$ \\
\hline 4000 & $2.90 \mathrm{E}+02$ & $2.43 \mathrm{E}-02$ & 1.65E-03 & $2.28 \mathrm{E}-04$ & $1.15 \mathrm{E}-02$ & $1.00 \mathrm{E}-18$ & $1.00 \mathrm{E}-18$ & $1.00 \mathrm{E}-18$ & $1.00 \mathrm{E}-18$ & $1.00 \mathrm{E}-18$ & $1.00 \mathrm{E}-18$ \\
\hline 4500 & $2.73 \mathrm{E}+02$ & $6.75 \mathrm{E}-02$ & 4.60E-03 & $6.31 \mathrm{E}-04$ & 3.19E-02 & $1.00 \mathrm{E}-18$ & $1.00 \mathrm{E}-18$ & $1.00 \mathrm{E}-18$ & $1.00 \mathrm{E}-18$ & $1.00 \mathrm{E}-18$ & $1.00 \mathrm{E}-18$ \\
\hline 5000 & $2.58 \mathrm{E}+02$ & 1.42E-01 & 9.67E-03 & 1.33E-03 & $6.70 \mathrm{E}-02$ & $1.00 \mathrm{E}-18$ & $1.00 \mathrm{E}-18$ & $1.00 \mathrm{E}-18$ & $1.00 \mathrm{E}-18$ & $1.00 \mathrm{E}-18$ & $1.00 \mathrm{E}-18$ \\
\hline 6000 & $2.33 \mathrm{E}+02$ & 3.68E-01 & 2.52E-02 & 3.46E-03 & $1.74 \mathrm{E}-01$ & $1.00 \mathrm{E}-18$ & $1.00 \mathrm{E}-18$ & $1.00 \mathrm{E}-18$ & $1.00 \mathrm{E}-18$ & $1.00 \mathrm{E}-18$ & $1.00 \mathrm{E}-18$ \\
\hline 7000 & $2.06 \mathrm{E}+02$ & 6.47E-01 & 4.43E-02 & 6.10E-03 & 3.08E-01 & $1.00 \mathrm{E}-18$ & $1.00 \mathrm{E}-18$ & $1.00 \mathrm{E}-18$ & $1.00 \mathrm{E}-18$ & $1.00 \mathrm{E}-18$ & $1.00 \mathrm{E}-18$ \\
\hline 8000 & $1.71 \mathrm{E}+02$ & 9.32E-01 & 6.45E-02 & 8.81E-03 & 4.44E-01 & $1.00 \mathrm{E}-18$ & $1.00 \mathrm{E}-18$ & $1.00 \mathrm{E}-18$ & $1.00 \mathrm{E}-18$ & $1.00 \mathrm{E}-18$ & $1.00 \mathrm{E}-18$ \\
\hline 9000 & $1.35 \mathrm{E}+02$ & $1.20 \mathrm{E}+00$ & 8.31E-02 & $1.14 \mathrm{E}-02$ & $5.75 \mathrm{E}-01$ & $1.00 \mathrm{E}-18$ & $1.00 \mathrm{E}-18$ & $1.00 \mathrm{E}-18$ & $1.00 \mathrm{E}-18$ & $1.00 \mathrm{E}-18$ & $1.00 \mathrm{E}-18$ \\
\hline 10000 & $1.05 E+02$ & $1.45 \mathrm{E}+00$ & $1.01 \mathrm{E}-01$ & 1.38E-02 & 6.96E-01 & $1.00 \mathrm{E}-18$ & $1.00 \mathrm{E}-18$ & $1.00 \mathrm{E}-18$ & $1.00 \mathrm{E}-18$ & $1.00 \mathrm{E}-18$ & $1.00 \mathrm{E}-18$ \\
\hline
\end{tabular}

Notes to Table 4-5:

- Conservative case inventory and $U$ source $K_{d}=365 \mathrm{~mL} / \mathrm{g}$.

- Average concentration at seep along the West Ditch with no surface water mixing.

- $1.00 \mathrm{E}-18$ represents a zero value. 
Table 4-6. POA-3 GW Sensitivity Case \#1

\begin{tabular}{|c|c|c|c|c|c|c|c|c|c|c|c|}
\hline \multirow{2}{*}{$\begin{array}{c}\text { Time } \\
\text { (year) }\end{array}$} & \multicolumn{11}{|c|}{ Activity Concentration $(\rho \mathrm{Ci} / \mathrm{L})$} \\
\hline & Tc-99 & U-234 & U-235 & U-236 & $\mathrm{U}-238$ & Am-241 & Np-237 & Pu-238 & Pu-239 & Th-228 & Th-230 \\
\hline 0 & $1.00 \mathrm{E}-18$ & $1.00 \mathrm{E}-18$ & $1.00 \mathrm{E}-18$ & $1.00 \mathrm{E}-18$ & $1.00 \mathrm{E}-18$ & $1.00 \mathrm{E}-18$ & $1.00 \mathrm{E}-18$ & $1.00 \mathrm{E}-18$ & $1.00 \mathrm{E}-18$ & $1.00 \mathrm{E}-18$ & $1.00 \mathrm{E}-18$ \\
\hline 500 & $1.00 \mathrm{E}-18$ & $1.00 \mathrm{E}-18$ & $1.00 \mathrm{E}-18$ & $1.00 \mathrm{E}-18$ & $.00 \mathrm{E}-18$ & $1.00 \mathrm{E}-18$ & $1.00 \mathrm{E}-18$ & $1.00 \mathrm{E}-18$ & $1.00 \mathrm{E}-18$ & $1.00 \mathrm{E}-18$ & $1.00 \mathrm{E}-18$ \\
\hline 600 & $.00 \mathrm{E}-18$ & $1.00 \mathrm{E}-18$ & $1.00 \mathrm{E}-18$ & $1.00 \mathrm{E}-18$ & 0E-18 & 00E-18 & $.00 \mathrm{E}-18$ & $1.00 \mathrm{E}-18$ & $1.00 \mathrm{E}-18$ & $1.00 \mathrm{E}-18$ & $1.00 \mathrm{E}-18$ \\
\hline 700 & 00E-18 & $.00 \mathrm{E}-18$ & 1.00E-18 & 1.00E-18 & & & & 1.00E-18 & 1.00E-18 & $1.00 \mathrm{E}-18$ & $1.00 \mathrm{E}-18$ \\
\hline 800 & 00E-18 & $0 \mathrm{E}-18$ & $0 \mathrm{E}-18$ & & & & & & & & \\
\hline 900 & $1.00 \mathrm{E}-18$ & $1.00 \mathrm{E}-18$ & $1.00 \mathrm{E}-18$ & $1.00 \mathrm{E}-18$ & $1.00 \mathrm{E}-18$ & $1.00 \mathrm{E}-18$ & $1.00 \mathrm{E}-18$ & 1.00E-18 & $1.00 \mathrm{E}-18$ & 1.00E-18 & $1.00 \mathrm{E}-18$ \\
\hline 1000 & 00E-18 & $.00 \mathrm{E}-18$ & $1.00 \mathrm{E}-18$ & $1.00 \mathrm{E}-18$ & $1.00 \mathrm{E}-18$ & $1.00 \mathrm{E}-18$ & $1.00 \mathrm{E}-18$ & $1.00 \mathrm{E}-18$ & $1.00 \mathrm{E}-18$ & $1.00 \mathrm{E}-18$ & $1.00 \mathrm{E}-18$ \\
\hline 1250 & $1.00 \mathrm{E}-18$ & $1.00 \mathrm{E}-18$ & $1.00 \mathrm{E}-18$ & $1.00 \mathrm{E}-18$ & & & & $1.00 \mathrm{E}-18$ & & $1.00 \mathrm{E}-18$ & $1.00 \mathrm{E}-18$ \\
\hline 1500 & $1.00 \mathrm{E}-18$ & $1.00 \mathrm{E}-18$ & $1.00 \mathrm{E}-18$ & $1.00 \mathrm{E}-18$ & & & & $1.00 \mathrm{E}-18$ & & & \\
\hline 2000 & $1.00 \mathrm{E}-18$ & $1.00 \mathrm{E}-18$ & $1.00 \mathrm{E}-18$ & $1.00 \mathrm{E}-18$ & $1.00 \mathrm{E}-18$ & $1.00 \mathrm{E}-18$ & $1.00 \mathrm{E}-18$ & $1.00 \mathrm{E}-18$ & $1.00 \mathrm{E}-18$ & $1.00 \mathrm{E}-18$ & $1.00 \mathrm{E}-18$ \\
\hline 2500 & $1.00 \mathrm{E}-18$ & $1.00 \mathrm{E}-18$ & $1.00 \mathrm{E}-18$ & $1.00 \mathrm{E}-18$ & $1.00 \mathrm{E}-18$ & $1.00 \mathrm{E}-18$ & $1.00 \mathrm{E}-18$ & $1.00 \mathrm{E}-18$ & $1.00 \mathrm{E}-18$ & $1.00 \mathrm{E}-18$ & $1.00 \mathrm{E}-18$ \\
\hline 3000 & $1.00 \mathrm{E}-18$ & $1.00 \mathrm{E}-18$ & $1.00 \mathrm{E}-18$ & $1.00 \mathrm{E}-18$ & $1.00 \mathrm{E}-18$ & $1.00 \mathrm{E}-18$ & $1.00 \mathrm{E}-18$ & $1.00 \mathrm{E}-18$ & $1.00 \mathrm{E}-18$ & $1.00 \mathrm{E}-18$ & $1.00 \mathrm{E}-18$ \\
\hline 3500 & $1.00 \mathrm{E}-18$ & & & & & & & & & & \\
\hline 4000 & $1.00 \mathrm{E}-18$ & $1.00 \mathrm{E}-18$ & 1.00E-18 & & & & & $1.00 \mathrm{E}-18$ & & $1.00 \mathrm{E}-18$ & E-18 \\
\hline 4500 & $1.00 \mathrm{E}-18$ & $1.00 \mathrm{E}-18$ & 1.00E-18 & $1.00 \mathrm{E}-18$ & $1.00 \mathrm{E}-18$ & $1.00 \mathrm{E}-18$ & $1.00 \mathrm{E}-18$ & $1.00 \mathrm{E}-18$ & $1.00 \mathrm{E}-18$ & $1.00 \mathrm{E}-18$ & $1.00 \mathrm{E}-18$ \\
\hline 5000 & $1.00 \mathrm{E}-18$ & & & & & & & & & & $1.00 \mathrm{E}-18$ \\
\hline 6000 & $1.00 \mathrm{E}-18$ & $1.00 \mathrm{E}-18$ & $1.00 \mathrm{E}-18$ & $1.00 \mathrm{E}-18$ & $1.00 \mathrm{E}-18$ & $1.00 \mathrm{E}-18$ & $1.00 \mathrm{E}-18$ & $1.00 \mathrm{E}-18$ & $1.00 \mathrm{E}-18$ & $1.00 \mathrm{E}-18$ & $1.00 \mathrm{E}-18$ \\
\hline 7000 & $1.00 \mathrm{E}-18$ & 1.00E-18 & $1.00 \mathrm{E}-18$ & $1.00 \mathrm{E}-18$ & $1.00 \mathrm{E}-18$ & $1.00 \mathrm{E}-18$ & $1.00 \mathrm{E}-18$ & $1.00 \mathrm{E}-18$ & $1.00 \mathrm{E}-18$ & $1.00 \mathrm{E}-18$ & $1.00 \mathrm{E}-18$ \\
\hline 8000 & $1.00 \mathrm{E}-18$ & $1.00 \mathrm{E}-18$ & $1.00 \mathrm{E}-18$ & $1.00 \mathrm{E}-18$ & $1.00 \mathrm{E}-18$ & $1.00 \mathrm{E}-18$ & $1.00 \mathrm{E}-18$ & $1.00 \mathrm{E}-18$ & $1.00 \mathrm{E}-18$ & $1.00 \mathrm{E}-18$ & $1.00 \mathrm{E}-18$ \\
\hline 9000 & $1.00 \mathrm{E}-18$ & $1.00 \mathrm{E}-18$ & $1.00 \mathrm{E}-18$ & $1.00 \mathrm{E}-18$ & $1.00 \mathrm{E}-18$ & $1.00 \mathrm{E}-18$ & $1.00 \mathrm{E}-18$ & $1.00 \mathrm{E}-18$ & $1.00 \mathrm{E}-18$ & $1.00 \mathrm{E}-18$ & $1.00 \mathrm{E}-18$ \\
\hline 10000 & $1.00 \mathrm{E}-18$ & $1.00 \mathrm{E}-18$ & $1.00 \mathrm{E}-18$ & $1.00 \mathrm{E}-18$ & $1.00 \mathrm{E}-18$ & $1.00 \mathrm{E}-18$ & $1.00 \mathrm{E}-18$ & $1.00 \mathrm{E}-18$ & $1.00 \mathrm{E}-18$ & $1.00 \mathrm{E}-18$ & $1.00 \mathrm{E}-18$ \\
\hline
\end{tabular}

Notes to Table 4-6:

- Groundwater well in Berea aquifer.

- Conservative case inventory, 100\% Berea groundwater, and U source $\mathrm{K}_{\mathrm{d}}=365 \mathrm{~mL} / \mathrm{g}$.

- $1.00 \mathrm{E}-18$ represents a zero value. 
Table 4-7. POA-3 GW Sensitivity Case \#2

\begin{tabular}{|c|c|c|c|c|c|c|c|c|c|c|c|}
\hline \multirow{2}{*}{$\begin{array}{l}\text { Time } \\
\text { (year) }\end{array}$} & \multicolumn{11}{|c|}{ Activity Concentration $(\rho \mathrm{Ci} / \mathrm{L})$} \\
\hline & Tc-99 & U-234 & U-235 & U-236 & U-238 & Am-241 & Np-237 & Pu-238 & Pu-239 & Th-228 & Th-230 \\
\hline 0 & $1.00 \mathrm{E}-18$ & $1.00 \mathrm{E}-18$ & $1.00 \mathrm{E}-18$ & $1.00 \mathrm{E}-18$ & $1.00 \mathrm{E}-18$ & $1.00 \mathrm{E}-18$ & $1.00 \mathrm{E}-18$ & $1.00 \mathrm{E}-18$ & $1.00 \mathrm{E}-18$ & $1.00 \mathrm{E}-18$ & $1.00 \mathrm{E}-18$ \\
\hline 500 & $1.00 \mathrm{E}-18$ & $1.00 \mathrm{E}-18$ & $1.00 \mathrm{E}-18$ & $1.00 \mathrm{E}-18$ & & & $1.00 \mathrm{E}-18$ & $1.00 \mathrm{E}-18$ & $1.00 \mathrm{E}-18$ & $1.00 \mathrm{E}-18$ & $1.00 \mathrm{E}-18$ \\
\hline 600 & $1.00 \mathrm{E}-18$ & $1.00 \mathrm{E}-18$ & $1.00 \mathrm{E}-18$ & $1.00 \mathrm{E}-18$ & $1.00 \mathrm{E}-18$ & & $1.00 \mathrm{E}-18$ & & $1.00 \mathrm{E}-18$ & $1.00 \mathrm{E}-18$ & $1.00 \mathrm{E}-18$ \\
\hline 700 & $1.00 \mathrm{E}-18$ & $1.00 \mathrm{E}-18$ & $1.00 \mathrm{E}-18$ & $1.00 \mathrm{E}-18$ & & & & $.00 \mathrm{E}-18$ & $1.00 \mathrm{E}-18$ & $1.00 \mathrm{E}-18$ & $1.00 \mathrm{E}-18$ \\
\hline 800 & $1.85 \mathrm{E}-11$ & $1.00 \mathrm{E}-18$ & $1.00 \mathrm{E}-18$ & $1.00 \mathrm{E}-18$ & $1.00 \mathrm{E}-18$ & $1.00 \mathrm{E}-18$ & $1.00 \mathrm{E}-18$ & $1.00 \mathrm{E}-18$ & $1.00 \mathrm{E}-18$ & $1.00 \mathrm{E}-18$ & $1.00 \mathrm{E}-18$ \\
\hline 900 & 1.52E-09 & 1.00E-18 & $1.00 \mathrm{E}-18$ & $1.00 \mathrm{E}-18$ & $1.00 \mathrm{E}-18$ & $1.00 \mathrm{E}-18$ & 1.00E-18 & 1.00E-18 & $1.00 \mathrm{E}-18$ & $1.00 \mathrm{E}-18$ & $1.00 \mathrm{E}-18$ \\
\hline 1000 & 2.81E-08 & 1.00E-18 & $1.00 \mathrm{E}-18$ & $1.00 \mathrm{E}-18$ & $1.00 \mathrm{E}-18$ & & 1.00E-18 & & & $1.00 \mathrm{E}-18$ & 00E-18 \\
\hline 1250 & 4.53E-05 & 1.00E-18 & $2.99 \mathrm{E}-16$ & 1.00E-18 & $2.96 \mathrm{E}-15$ & E-18 & 0E-18 & 1.00E-18 & $1.00 \mathrm{E}$ & $1.00 \mathrm{E}-18$ & \\
\hline 1500 & 2.45E-02 & 1.79E-12 & 1.49E-13 & 1.72E-14 & 1.07E-12 & 0 E-18 & $1.00 \mathrm{E}-18$ & 1.00E-18 & $1.00 \mathrm{E}-18$ & $1.00 \mathrm{E}-18$ & $1.00 \mathrm{E}-18$ \\
\hline 2000 & $1.16 \mathrm{E}+01$ & $2.55 \mathrm{E}-08$ & 1.84E-09 & $2.48 \mathrm{E}-10$ & 1.32E-08 & $1.00 \mathrm{E}-18$ & $1.00 \mathrm{E}-18$ & $1.00 \mathrm{E}-18$ & $1.00 \mathrm{E}-18$ & $1.00 \mathrm{E}-18$ & $1.00 \mathrm{E}-18$ \\
\hline 2500 & $3.91 \mathrm{E}+01$ & 5.97E-06 & 4.32E-07 & $5.80 \mathrm{E}-08$ & & & & & & & \\
\hline 3000 & $6.68 \mathrm{E}+01$ & & & & & & & & & & $1.00 \mathrm{E}-18$ \\
\hline 3500 & $1.04 \mathrm{E}+02$ & $1.87 \mathrm{E}-03$ & 1.35E-04 & 1.83E-05 & 9.73E-04 & $1.00 \mathrm{E}-18$ & $1.00 \mathrm{E}-18$ & $1.00 \mathrm{E}-18$ & $1.00 \mathrm{E}-18$ & $1.00 \mathrm{E}-18$ & 0E-18 \\
\hline 4000 & $2.24 \mathrm{E}+02$ & $7.95 \mathrm{E}-03$ & $5.75 \mathrm{E}-04$ & $7.80 \mathrm{E}-05$ & $4.14 \mathrm{E}-03$ & $1.00 \mathrm{E}-18$ & $1.00 \mathrm{E}-18$ & $1.00 \mathrm{E}-18$ & $1.00 \mathrm{E}-18$ & $1.00 \mathrm{E}-18$ & $1.00 \mathrm{E}-18$ \\
\hline 4500 & $3.41 \mathrm{E}+02$ & $2.24 \mathrm{E}-02$ & $1.63 \mathrm{E}-03$ & $2.20 \mathrm{E}-04$ & & & & & & $1.00 \mathrm{E}-18$ & $1.00 \mathrm{E}-18$ \\
\hline 5000 & $4.24 \mathrm{E}+02$ & 4.33E-02 & 3.13E-03 & $4.23 \mathrm{E}-04$ & $2.25 \mathrm{E}-02$ & $1.00 \mathrm{E}-18$ & $1.00 \mathrm{E}-18$ & $1.00 \mathrm{E}-18$ & $1.00 \mathrm{E}-18$ & $1.00 \mathrm{E}-18$ & $1.00 \mathrm{E}-18$ \\
\hline 6000 & $8.52 E+02$ & $1.01 \mathrm{E}-01$ & 7.37E-03 & 9.93E-04 & 5.28E-02 & $1.00 \mathrm{E}-18$ & 1.00E-18 & $1.00 \mathrm{E}-18$ & $1.00 \mathrm{E}-18$ & $1.00 \mathrm{E}-18$ & $1.00 \mathrm{E}-18$ \\
\hline 7000 & $1.16 \mathrm{E}+03$ & $1.61 \mathrm{E}-01$ & $1.18 \mathrm{E}-02$ & 1.59E-03 & 8.46E-02 & $1.00 \mathrm{E}-18$ & $1.00 \mathrm{E}-18$ & $1.00 \mathrm{E}-18$ & $1.00 \mathrm{E}-18$ & $1.00 \mathrm{E}-18$ & $1.00 \mathrm{E}-18$ \\
\hline 8000 & $1.16 \mathrm{E}+03$ & 2.35E-01 & 1.73E-02 & 2.33E-03 & $1.24 \mathrm{E}-01$ & $1.00 \mathrm{E}-18$ & $1.00 \mathrm{E}-18$ & $1.00 \mathrm{E}-18$ & $1.00 \mathrm{E}-18$ & $1.00 \mathrm{E}-18$ & $1.00 \mathrm{E}-18$ \\
\hline 9000 & $9.89 \mathrm{E}+02$ & 3.11E-01 & $2.29 \mathrm{E}-02$ & $3.10 \mathrm{E}-03$ & $1.64 \mathrm{E}-01$ & $1.00 \mathrm{E}-18$ & $1.00 \mathrm{E}-18$ & $1.00 \mathrm{E}-18$ & $1.00 \mathrm{E}-18$ & $1.00 \mathrm{E}-18$ & $1.00 \mathrm{E}-18$ \\
\hline 10000 & $8.08 \mathrm{E}+02$ & 3.89E-01 & $2.87 \mathrm{E}-02$ & $3.88 \mathrm{E}-03$ & $2.05 \mathrm{E}-01$ & $1.00 \mathrm{E}-18$ & $1.00 \mathrm{E}-18$ & $1.00 \mathrm{E}-18$ & $1.00 \mathrm{E}-18$ & $1.00 \mathrm{E}-18$ & $1.00 \mathrm{E}-18$ \\
\hline
\end{tabular}

Notes to Table 4-7:

- Reasonable case inventory, 95\% Berea groundwater and 5\% 680 SSL, and U source $\mathrm{K}_{\mathrm{d}}=365 \mathrm{~mL} / \mathrm{g}$.

- Open hole groundwater well to Berea with $5 \%$ of groundwater from maximum concentration location in 680 sandstone layer (SSL) anywhere along the edge of the $100 \mathrm{~m}$ buffer from the OSWDF.

- $1.00 \mathrm{E}-18$ represents a zero value. 
Table 4-8. POA-1 SW Zone Sensitivity Case \#3

\begin{tabular}{|c|c|c|c|c|c|c|c|c|c|c|c|}
\hline \multirow{2}{*}{$\begin{array}{c}\text { Time } \\
\text { (year) }\end{array}$} & \multicolumn{11}{|c|}{ Activity Concentration $(\rho \mathrm{Ci} / \mathrm{L})$} \\
\hline & Tc-99 & U-234 & U-235 & U-236 & U-238 & Am-241 & Np-237 & Pu-238 & Pu-239 & Th-228 & Th-230 \\
\hline 0 & 1.00E-18 & $1.00 \mathrm{E}-18$ & $1.00 \mathrm{E}-18$ & $1.00 \mathrm{E}-18$ & $1.00 \mathrm{E}-18$ & $1.00 \mathrm{E}-18$ & $1.00 \mathrm{E}-18$ & 1.00E-18 & 1.00E-18 & 1.00E-18 & $1.00 \mathrm{E}-18$ \\
\hline 500 & 00E-18 & $1.00 \mathrm{E}-18$ & $1.00 \mathrm{E}-18$ & $1.00 \mathrm{E}-18$ & $1.00 \mathrm{E}-18$ & $.00 \mathrm{E}-18$ & $1.00 \mathrm{E}-18$ & $1.00 \mathrm{E}-18$ & $1.00 \mathrm{E}-18$ & $1.00 \mathrm{E}-18$ & $1.00 \mathrm{E}-18$ \\
\hline 600 & $.00 \mathrm{E}-18$ & 1.00E-18 & $1.00 \mathrm{E}-18$ & $1.00 \mathrm{E}-18$ & $1.00 \mathrm{E}-18$ & 00E-18 & $1.00 \mathrm{E}-18$ & $.00 \mathrm{E}-18$ & $1.00 \mathrm{E}-18$ & 1.00E-18 & $1.00 \mathrm{E}-18$ \\
\hline 700 & $1.00 \mathrm{E}-18$ & $1.00 \mathrm{E}-18$ & $1.00 \mathrm{E}-18$ & $1.00 \mathrm{E}-18$ & $1.00 \mathrm{E}-18$ & $1.00 \mathrm{E}-18$ & $1.00 \mathrm{E}-18$ & $1.00 \mathrm{E}-18$ & $1.00 \mathrm{E}-18$ & $1.00 \mathrm{E}-18$ & $1.00 \mathrm{E}-18$ \\
\hline 800 & $1.00 \mathrm{E}-18$ & $1.00 \mathrm{E}-18$ & $1.00 \mathrm{E}-18$ & $1.00 \mathrm{E}-18$ & $1.00 \mathrm{E}-18$ & $1.00 \mathrm{E}-18$ & $1.00 \mathrm{E}-18$ & $1.00 \mathrm{E}-18$ & $1.00 \mathrm{E}-18$ & $1.00 \mathrm{E}-18$ & $1.00 \mathrm{E}-18$ \\
\hline 900 & 1.00E-18 & $1.00 \mathrm{E}-18$ & $1.00 \mathrm{E}-18$ & $1.00 \mathrm{E}-18$ & $1.00 \mathrm{E}-18$ & 1.00E-18 & $1.00 \mathrm{E}-18$ & 1.00E-18 & $1.00 \mathrm{E}-18$ & $1.00 \mathrm{E}-18$ & $1.00 \mathrm{E}-18$ \\
\hline 1000 & $7.87 \mathrm{E}-11$ & $1.00 \mathrm{E}-18$ & $1.00 \mathrm{E}-18$ & $1.00 \mathrm{E}-18$ & $1.00 \mathrm{E}-18$ & $0 \mathrm{E}-18$ & $1.00 \mathrm{E}-18$ & $1.00 \mathrm{I}$ & 1.00 & $1.00 \mathrm{E}-18$ & $1.00 \mathrm{E}-18$ \\
\hline 1250 & 16E-07 & $1.00 \mathrm{E}-18$ & $1.00 \mathrm{E}-18$ & $1.00 \mathrm{E}-18$ & $1.00 \mathrm{E}-18$ & $0 \mathrm{E}-18$ & $1.00 \mathrm{E}-18$ & 1.00E-18 & E-18 & $1.00 \mathrm{E}-18$ & $1.00 \mathrm{E}-18$ \\
\hline 1500 & 58E-04 & $1.00 \mathrm{E}-18$ & 1.83E-15 & $1.00 \mathrm{E}-18$ & $1.58 \mathrm{E}-14$ & E-18 & $1.00 \mathrm{E}-18$ & -18 & -18 & $1.00 \mathrm{E}$ & $1.00 \mathrm{E}-18$ \\
\hline 2000 & & & & & & & -18 & & & & \\
\hline 2500 & $2.40 \mathrm{E}+00$ & $3.51 \mathrm{E}-07$ & 2.53E-08 & 3.43E-09 & & & & & & $1.00 \mathrm{E}-18$ & $1.00 \mathrm{E}-18$ \\
\hline 3000 & $6.30 \mathrm{E}+00$ & $1.82 \mathrm{E}-05$ & $1.32 \mathrm{E}-06$ & 1.79E-07 & 9.50E-06 & $1.00 \mathrm{E}-18$ & $1.00 \mathrm{E}-18$ & $1.00 \mathrm{E}-18$ & $1.00 \mathrm{E}-18$ & $1.00 \mathrm{E}-18$ & $1.00 \mathrm{E}-18$ \\
\hline 3500 & $9.46 \mathrm{E}+00$ & $2.80 \mathrm{E}-04$ & $2.04 \mathrm{E}-05$ & $2.74 \mathrm{E}-06$ & $1.46 \mathrm{E}-04$ & $1.00 \mathrm{E}-18$ & $1.00 \mathrm{E}-18$ & $1.00 \mathrm{E}-18$ & $1.00 \mathrm{E}-18$ & $1.00 \mathrm{E}-18$ & $1.00 \mathrm{E}-18$ \\
\hline 4000 & $1.06 \mathrm{E}+01$ & $2.02 \mathrm{E}-03$ & $1.47 \mathrm{E}-04$ & $1.98 \mathrm{E}-05$ & $1.06 \mathrm{E}-03$ & $1.00 \mathrm{E}-18$ & $1.00 \mathrm{E}-18$ & $1.00 \mathrm{E}-18$ & $1.00 \mathrm{E}-18$ & $1.00 \mathrm{E}-18$ & $1.00 \mathrm{E}-18$ \\
\hline 4500 & $1.01 \mathrm{E}+01$ & 8.72E-03 & $6.34 \mathrm{E}-04$ & $8.57 \mathrm{E}-05$ & $4.54 \mathrm{E}-03$ & $1.00 \mathrm{E}-18$ & $1.00 \mathrm{E}-18$ & $1.00 \mathrm{E}-18$ & $1.00 \mathrm{E}-18$ & $1.00 \mathrm{E}-18$ & $1.00 \mathrm{E}-18$ \\
\hline 5000 & $8.77 \mathrm{E}+00$ & $2.64 \mathrm{E}-02$ & $1.93 \mathrm{E}-03$ & $2.60 \mathrm{E}-04$ & $1.38 \mathrm{E}-02$ & $1.00 \mathrm{E}-18$ & $1.00 \mathrm{E}-18$ & $1.00 \mathrm{E}-18$ & $1.00 \mathrm{E}-18$ & $1.00 \mathrm{E}-18$ & $1.00 \mathrm{E}-18$ \\
\hline 6000 & $6.48 \mathrm{E}+00$ & $1.20 \mathrm{E}-01$ & 8.72E-03 & $1.18 \mathrm{E}-03$ & 6.27E-02 & $1.00 \mathrm{E}-18$ & $1.00 \mathrm{E}-18$ & $1.00 \mathrm{E}-18$ & $1.00 \mathrm{E}-18$ & $1.00 \mathrm{E}-18$ & $1.00 \mathrm{E}-18$ \\
\hline 7000 & $5.51 \mathrm{E}+00$ & 3.04E-01 & 2.23E-02 & $3.02 \mathrm{E}-03$ & $1.60 \mathrm{E}-01$ & & $1.00 \mathrm{E}-18$ & $1.00 \mathrm{E}-18$ & $1.00 \mathrm{E}-18$ & $1.00 \mathrm{E}-18$ & $1.00 \mathrm{E}-18$ \\
\hline 8000 & $4.95 \mathrm{E}+00$ & 5.65E-01 & 4.15E-02 & 5.61E-03 & 2.98E-01 & $1.00 \mathrm{E}-18$ & $1.00 \mathrm{E}-18$ & $1.00 \mathrm{E}-18$ & $1.00 \mathrm{E}-18$ & $1.00 \mathrm{E}-18$ & $1.00 \mathrm{E}-18$ \\
\hline 9000 & $4.38 \mathrm{E}+00$ & 8.70E-01 & $6.42 \mathrm{E}-02$ & 8.66E-03 & $4.60 \mathrm{E}-01$ & $1.00 \mathrm{E}-18$ & $1.00 \mathrm{E}-18$ & $1.00 \mathrm{E}-18$ & $1.00 \mathrm{E}-18$ & $1.00 \mathrm{E}-18$ & $1.00 \mathrm{E}-18$ \\
\hline 10000 & $3.72 \mathrm{E}+00$ & $1.18 \mathrm{E}+00$ & 8.72E-02 & $1.18 \mathrm{E}-02$ & 6.27E-01 & $1.00 \mathrm{E}-18$ & $1.00 \mathrm{E}-18$ & $1.00 \mathrm{E}-18$ & $1.00 \mathrm{E}-18$ & $1.00 \mathrm{E}-18$ & $1.00 \mathrm{E}-18$ \\
\hline
\end{tabular}

Notes to Table 4-8:

- $\quad$ Reasonable case inventory and $U$ source $K_{d}=14.6 \mathrm{~mL} / \mathrm{g}$.

- Average concentration at seep along the West Ditch with no surface water mixing.

- $1.00 \mathrm{E}-18$ represents a zero value. 
Table 4-9. POA-3 GW Sensitivity Case \#3

\begin{tabular}{|c|c|c|c|c|c|c|c|c|c|c|c|}
\hline \multirow{2}{*}{$\begin{array}{l}\text { Time } \\
\text { (year) }\end{array}$} & \multicolumn{11}{|c|}{ Activity Concentration $(\rho \mathrm{Ci} / \mathrm{L})$} \\
\hline & Tc-99 & U-234 & U-235 & U-236 & U-238 & Am-241 & Np-237 & Pu-238 & Pu-239 & Th-228 & Th-230 \\
\hline 0 & $1.00 \mathrm{E}-18$ & $1.00 \mathrm{E}-18$ & $1.00 \mathrm{E}-18$ & $1.00 \mathrm{E}-18$ & $1.00 \mathrm{E}-18$ & $1.00 \mathrm{E}-18$ & $1.00 \mathrm{E}-18$ & $1.00 \mathrm{E}-18$ & $1.00 \mathrm{E}-18$ & $1.00 \mathrm{E}-18$ & $1.00 \mathrm{E}-18$ \\
\hline 500 & $.00 \mathrm{E}-18$ & $.00 \mathrm{E}-18$ & $1.00 \mathrm{E}-18$ & $1.00 \mathrm{E}-18$ & $1.00 \mathrm{E}-18$ & $1.00 \mathrm{E}-18$ & $1.00 \mathrm{E}-18$ & $1.00 \mathrm{E}-18$ & $1.00 \mathrm{E}-18$ & $1.00 \mathrm{E}-18$ & $1.00 \mathrm{E}-18$ \\
\hline 600 & $.00 \mathrm{E}-18$ & $1.00 \mathrm{E}-18$ & $1.00 \mathrm{E}-18$ & $1.00 \mathrm{E}-18$ & $1.00 \mathrm{E}-18$ & $.00 \mathrm{E}-18$ & $.00 \mathrm{E}-18$ & 1.00E-18 & $1.00 \mathrm{E}-18$ & $1.00 \mathrm{E}-18$ & $1.00 \mathrm{E}-18$ \\
\hline 700 & $1.00 \mathrm{E}-18$ & $1.00 \mathrm{E}-18$ & $1.00 \mathrm{E}-18$ & $1.00 \mathrm{E}-18$ & $1.00 \mathrm{E}-18$ & $1.00 \mathrm{E}-18$ & $1.00 \mathrm{E}-18$ & $1.00 \mathrm{E}-18$ & $1.00 \mathrm{E}-18$ & $1.00 \mathrm{E}-18$ & $1.00 \mathrm{E}-18$ \\
\hline 800 & $.00 \mathrm{E}-18$ & $1.00 \mathrm{E}-18$ & $1.00 \mathrm{E}-18$ & $1.00 \mathrm{E}-18$ & $1.00 \mathrm{E}-18$ & $1.00 \mathrm{E}-18$ & $1.00 \mathrm{E}-18$ & 1.00E-18 & $1.00 \mathrm{E}-18$ & $1.00 \mathrm{E}-18$ & $1.00 \mathrm{E}-18$ \\
\hline 900 & $1.00 \mathrm{E}-18$ & $1.00 \mathrm{E}-18$ & $1.00 \mathrm{E}-18$ & $1.00 \mathrm{E}-18$ & $1.00 \mathrm{E}-18$ & $1.00 \mathrm{E}-18$ & $1.00 \mathrm{E}-18$ & 1.00E-18 & $1.00 \mathrm{E}-18$ & $1.00 \mathrm{E}-18$ & $1.00 \mathrm{E}-18$ \\
\hline 1000 & $1.00 \mathrm{E}-18$ & $1.00 \mathrm{E}-18$ & $1.00 \mathrm{E}-18$ & $1.00 \mathrm{E}-18$ & $1.00 \mathrm{E}-18$ & $1.00 \mathrm{E}-18$ & $1.00 \mathrm{E}-18$ & $1.00 \mathrm{E}-18$ & $1.00 \mathrm{E}-18$ & $1.00 \mathrm{E}-18$ & $1.00 \mathrm{E}-18$ \\
\hline 1250 & $1.00 \mathrm{E}-18$ & $1.00 \mathrm{E}-18$ & $1.00 \mathrm{E}-18$ & $1.00 \mathrm{E}-18$ & $1.00 \mathrm{E}-18$ & $1.00 \mathrm{E}-18$ & $1.00 \mathrm{E}-18$ & 1.00E-18 & $1.00 \mathrm{E}-18$ & $1.00 \mathrm{E}-18$ & $1.00 \mathrm{E}-18$ \\
\hline 1500 & $1.00 \mathrm{E}-18$ & $1.00 \mathrm{E}-18$ & $1.00 \mathrm{E}-18$ & $1.00 \mathrm{E}-18$ & $1.00 \mathrm{E}-18$ & & $1.00 \mathrm{E}-18$ & $1.00 \mathrm{E}-18$ & $1.00 \mathrm{E}-18$ & $1.00 \mathrm{E}-18$ & $1.00 \mathrm{E}-18$ \\
\hline 2000 & & & & & & & & & & & \\
\hline 2500 & $1.00 \mathrm{E}-18$ & $1.00 \mathrm{E}-18$ & $1.00 \mathrm{E}-18$ & $1.00 \mathrm{E}-18$ & $1.00 \mathrm{E}-18$ & $1.00 \mathrm{E}-18$ & $1.00 \mathrm{E}-18$ & $1.00 \mathrm{E}-18$ & $1.00 \mathrm{E}-18$ & $1.00 \mathrm{E}-18$ & $1.00 \mathrm{E}-18$ \\
\hline 3000 & $1.00 \mathrm{E}-18$ & $1.00 \mathrm{E}-18$ & $1.00 \mathrm{E}-18$ & $1.00 \mathrm{E}-18$ & $1.00 \mathrm{E}-18$ & $1.00 \mathrm{E}-18$ & $1.00 \mathrm{E}-18$ & 1.00E-18 & $1.00 \mathrm{E}-18$ & $1.00 \mathrm{E}-18$ & $1.00 \mathrm{E}-18$ \\
\hline 3500 & $1.00 \mathrm{E}-18$ & $1.00 \mathrm{E}-18$ & $1.00 \mathrm{E}-18$ & $1.00 \mathrm{E}-18$ & $1.00 \mathrm{E}-18$ & $1.00 \mathrm{E}-18$ & $1.00 \mathrm{E}-18$ & $1.00 \mathrm{E}-18$ & $1.00 \mathrm{E}-18$ & $1.00 \mathrm{E}-18$ & $1.00 \mathrm{E}-18$ \\
\hline 4000 & $1.00 \mathrm{E}-18$ & $1.00 \mathrm{E}-18$ & $1.00 \mathrm{E}-18$ & $1.00 \mathrm{E}-18$ & & & & $1.00 \mathrm{E}-18$ & & $1.00 \mathrm{E}-18$ & $1.00 \mathrm{E}-18$ \\
\hline 4500 & $1.00 \mathrm{E}-18$ & $1.00 \mathrm{E}-18$ & $1.00 \mathrm{E}-18$ & $1.00 \mathrm{E}-18$ & $1.00 \mathrm{E}-18$ & $1.00 \mathrm{E}-18$ & $1.00 \mathrm{E}-18$ & $1.00 \mathrm{E}-18$ & $1.00 \mathrm{E}-18$ & $1.00 \mathrm{E}-18$ & $1.00 \mathrm{E}-18$ \\
\hline 5000 & $1.00 \mathrm{E}-18$ & $1.00 \mathrm{E}-18$ & $1.00 \mathrm{E}-18$ & $1.00 \mathrm{E}-18$ & $1.00 \mathrm{E}-18$ & $1.00 \mathrm{E}-18$ & $1.00 \mathrm{E}-18$ & $1.00 \mathrm{E}-18$ & $1.00 \mathrm{E}-18$ & $1.00 \mathrm{E}-18$ & $1.00 \mathrm{E}-18$ \\
\hline 6000 & $1.00 \mathrm{E}-18$ & $1.00 \mathrm{E}-18$ & $1.00 \mathrm{E}-18$ & $1.00 \mathrm{E}-18$ & $1.00 \mathrm{E}-18$ & $1.00 \mathrm{E}-18$ & $1.00 \mathrm{E}-18$ & $1.00 \mathrm{E}-18$ & $1.00 \mathrm{E}-18$ & $1.00 \mathrm{E}-18$ & $1.00 \mathrm{E}-18$ \\
\hline 7000 & $1.00 \mathrm{E}-18$ & $1.00 \mathrm{E}-18$ & $1.00 \mathrm{E}-18$ & $1.00 \mathrm{E}-18$ & $1.00 \mathrm{E}-18$ & $1.00 \mathrm{E}-18$ & $1.00 \mathrm{E}-18$ & 1.00E-18 & $1.00 \mathrm{E}-18$ & $1.00 \mathrm{E}-18$ & $1.00 \mathrm{E}-18$ \\
\hline 8000 & $1.00 \mathrm{E}-18$ & $1.00 \mathrm{E}-18$ & $1.00 \mathrm{E}-18$ & $1.00 \mathrm{E}-18$ & $1.00 \mathrm{E}-18$ & $1.00 \mathrm{E}-18$ & $1.00 \mathrm{E}-18$ & $1.00 \mathrm{E}-18$ & $1.00 \mathrm{E}-18$ & $1.00 \mathrm{E}-18$ & $1.00 \mathrm{E}-18$ \\
\hline 9000 & $1.00 \mathrm{E}-18$ & $1.00 \mathrm{E}-18$ & $1.00 \mathrm{E}-18$ & $1.00 \mathrm{E}-18$ & $1.00 \mathrm{E}-18$ & $1.00 \mathrm{E}-18$ & $1.00 \mathrm{E}-18$ & $1.00 \mathrm{E}-18$ & $1.00 \mathrm{E}-18$ & $1.00 \mathrm{E}-18$ & $1.00 \mathrm{E}-18$ \\
\hline 10000 & $1.00 \mathrm{E}-18$ & $1.00 \mathrm{E}-18$ & $1.00 \mathrm{E}-18$ & $1.00 \mathrm{E}-18$ & $1.00 \mathrm{E}-18$ & $1.00 \mathrm{E}-18$ & $1.00 \mathrm{E}-18$ & $1.00 \mathrm{E}-18$ & $1.00 \mathrm{E}-18$ & $1.00 \mathrm{E}-18$ & $1.00 \mathrm{E}-18$ \\
\hline
\end{tabular}

Notes to Table 4-9:

- Groundwater well in Berea aquifer.

- Reasonable case inventory, $100 \%$ Berea groundwater, and U source $\mathrm{K}_{\mathrm{d}}=14.6 \mathrm{~mL} / \mathrm{g}$.

- $1.00 \mathrm{E}-18$ represents a zero value. 
Table 4-10. Discharge Rate along the POA-1 SW Zone

\begin{tabular}{|c|c|c|}
\hline $\begin{array}{c}\text { Time } \\
\text { (year) }\end{array}$ & $\begin{array}{c}\text { Discharge Rate Along the } \\
\text { POA-1 SW Zone } \\
\text { (gpm) }\end{array}$ & $\begin{array}{c}\text { Discharge Rate Along the } \\
\text { POA-1 SW Zone } \\
\text { (L/yr) }\end{array}$ \\
\hline 0 & $0.00 \mathrm{E}+0$ & $0.00 \mathrm{E}+00$ \\
\hline 500 & $1.73 \mathrm{E}-06$ & $3.44 \mathrm{E}+00$ \\
\hline 1000 & $2.24 \mathrm{E}-02$ & $4.46 \mathrm{E}+04$ \\
\hline 1250 & $4.53 \mathrm{E}-02$ & $9.02 \mathrm{E}+04$ \\
\hline 1500 & $9.17 \mathrm{E}-02$ & $1.83 \mathrm{E}+05$ \\
\hline 2000 & $1.66 \mathrm{E}-01$ & $3.31 \mathrm{E}+05$ \\
\hline 2500 & $2.01 \mathrm{E}-01$ & $4.00 \mathrm{E}+05$ \\
\hline 3000 & $2.18 \mathrm{E}-01$ & $4.34 \mathrm{E}+05$ \\
\hline 3500 & $2.26 \mathrm{E}-01$ & $4.50 \mathrm{E}+05$ \\
\hline 4000 & $2.30 \mathrm{E}-01$ & $4.58 \mathrm{E}+05$ \\
\hline 4500 & $2.31 \mathrm{E}-01$ & $4.60 \mathrm{E}+05$ \\
\hline 5000 & $2.32 \mathrm{E}-01$ & $4.62 \mathrm{E}+05$ \\
\hline 6000 & $2.32 \mathrm{E}-01$ & $4.62 \mathrm{E}+05$ \\
\hline 7000 & $2.33 \mathrm{E}-01$ & $4.64 \mathrm{E}+05$ \\
\hline 8000 & $2.33 \mathrm{E}-01$ & $4.64 \mathrm{E}+05$ \\
\hline 9000 & $2.33 \mathrm{E}-01$ & $4.64 \mathrm{E}+05$ \\
\hline 10000 & $2.33 \mathrm{E}-01$ & $4.64 \mathrm{E}+05$ \\
\hline & & \\
\hline
\end{tabular}




\subsection{Other All-Pathways Dose Model Input}

As outlined in Section 2.0, it is assumed that the 680 SSL contaminated ground surface outcrop (i.e. POA-1 SW zone) is captured by a farm pond, which is used to irrigate a garden and pasture and water livestock from which food for the resident farmer is obtained. The concentration of the contaminants within the farm pond has been based upon the contaminant concentration and flow associated with the 680 SSL contaminated ground surface outcrop and the predicted annual water use requirements associated with the pond. Tables 4-3, 4-5, and 4-8 provide the STOMP modeled activity concentrations over time for various cases associated with the 680 SSL outcrop, and Table 4-10 provides the discharge rate over time along the POA-1 SW zone.

The garden and pasture irrigation water requirements provided in Table 5-1 were obtained from the Ohio Irrigation Guide (USDA 1970). The garden irrigation is a composite of the irrigation required for the following vegetables: lima beans, snap beans, cabbage, celery, sweet corn, cucumbers, lettuce, onions, green peas, peppers, early and late potatoes, radishes, and tomatoes. Because the garden and pasture irrigation water requirements are nearly identical the garden irrigation water requirements have been utilized to represent both garden and pasture irrigation. The livestock water requirements and resident farm size information provided in Table 5-2 and 5-3, respectively, were obtained from the RESRAD Version 6 User's Manual (Yu et al. 2001). Based upon the data provided in Tables 5-1 through 5-3, a resident farm predicted annual water usage of approximately 9,400,000 liters/yr was estimated as outlined in Table 5-4.

The discharge rate along the POA-1 SW zone ranges from 0 gpm at year zero to 0.233 gpm at year 10,000. Conservatively assuming a discharge rate of $0.233 \mathrm{gpm}$, results in an annual outcrop of approximately 465,000 liters/year (463,896 liter/year). On an annual basis this results in 465,000 liters of contaminated outcrop water within the resident farm water usage of 9,400,000 liters. Therefore the activity concentrations associated with the 680 SSL outcrop (i.e. Tables 4-3, 4-5, and 4-8) were divided by a factor of 20 to arrive at the activity concentrations within the farm pond (i.e. Tables 5-5, 5-6, and 5-7, respectively), which is used for irrigation and watering livestock.

The following other All-Pathways dose model input data are provided:

- Table 5-8 provides the decay chains (i.e. half-lives and branching fractions) for the parents and daughters associated with the OSWDF (ICRP 2008).

- Figures 5-1 through 5-5 provide pictorial representations of the decay chains.

- Table 5-9 provides the ingestion and inhalation dose coefficients (DOE 2011) and external soil exposure factors (EPA 1993 and Lee 2004).

- Table 5-10 provides the base case transfer factors (Baes et al. 1984, Lee 2004, Lee and Coffield 2008a, SRR 2012).

- Table 5-11 provides the sensitivity case \#4 transfer factors (Jannik et al. 2010 and SRR 2012).

- Table 5-12 provides the exposure parameters including consumption rates. Exposure parameters with Portsmouth site-specific values are highlighted in blue. The "Typical Person" exposure parameters are used for the base case, and the "Reference Person" exposure parameters are used for sensitivity case \#5.

- Table 5-13 provides the radionuclide soil/water partition coefficients $\left(K_{d} s\right)$ for the parents and daughters associated with the OSWDF. $\mathrm{K}_{d} \mathrm{~S}$ with Portsmouth site-specific values are highlighted in blue. 
Table 5-1. Ohio Net Irrigation Water Requirements (USDA 1970)

\begin{tabular}{|l|r|r|r|r|r|r|}
\hline $\begin{array}{c}\text { Ohio Net Irrigation } \\
\text { Water } \\
\text { Requirements }\end{array}$ & $\begin{array}{c}\text { May } \\
\text { (inches) }\end{array}$ & $\begin{array}{c}\text { June } \\
\text { (inches) }\end{array}$ & $\begin{array}{c}\text { July } \\
\text { (inches) }\end{array}$ & $\begin{array}{c}\text { August } \\
\text { (inches) }\end{array}$ & $\begin{array}{c}\text { September } \\
\text { (inches) }\end{array}$ & $\begin{array}{c}\text { Annual } \\
\text { Total } \\
\text { (inches) }\end{array}$ \\
\hline Garden Irrigation & 2.6 & 3.8 & 4.7 & 4.8 & 2.8 & 18.7 \\
\hline Pasture Irrigation & 1.9 & 3.8 & 4.7 & 4.3 & 2.8 & 17.5 \\
\hline
\end{tabular}

Table 5-2. Livestock Water Requirements (Yu et al. 2001)

\begin{tabular}{|l|r|}
\hline \multicolumn{1}{|c|}{ Livestock } & \multicolumn{2}{|c|}{$\begin{array}{c}\text { Water Requirements } \\
\text { (L/d) }\end{array}$} \\
\hline Beef Cow & \\
\hline Milk Cow & 28 \\
\hline Poultry & 50 \\
\hline
\end{tabular}

Table 5-3. Resident Farm Size (Yu et al. 2001)

\begin{tabular}{|l|r|}
\hline \multicolumn{1}{|c|}{ Resident Farm } & \multicolumn{1}{c|}{ Size } \\
\hline Garden Size & 0.1 ha \\
\hline Pasture Size & 2 ha \\
\hline Number of Beef Cows & 1 each \\
\hline Number of Milk Cows & 1 each \\
\hline Number of Chickens & 10 each \\
\hline
\end{tabular}

Table 5-4. Resident Farm Annual Water Usage

\begin{tabular}{|c|c|}
\hline Resident Farm & $\begin{array}{c}\text { Annual Water Usage } \\
\text { (L/year) }\end{array}$ \\
\hline Garden & 474,980 \\
\hline Pasture & $8,889,995$ \\
\hline Beef Cow & 10,227 \\
\hline Milk Cow & 18,263 \\
\hline Poultry & 1,096 \\
\hline Total & $9,394,560$ \\
\hline
\end{tabular}


Table 5-5. Base Case Irrigation and Watering Pond

\begin{tabular}{|c|c|c|c|c|c|c|c|c|c|c|c|}
\hline \multirow{2}{*}{$\begin{array}{l}\text { Time } \\
\text { (year) }\end{array}$} & \multicolumn{11}{|c|}{ Activity Concentration ( $\rho \mathrm{Ci} / \mathrm{L})$} \\
\hline & Tc-99 & $\mathrm{U}-234$ & $\mathrm{U}-235$ & $\mathrm{U}-236$ & U-238 & Am-241 & Np-237 & Pu-238 & Pu-239 & Th-228 & Th-230 \\
\hline 0 & $1.00 \mathrm{E}-18$ & $1.00 \mathrm{E}-18$ & $1.00 \mathrm{E}-18$ & 1.00E-18 & 1.00E-18 & $1.00 \mathrm{E}-18$ & $1.00 \mathrm{E}-18$ & $1.00 \mathrm{E}-18$ & $1.00 \mathrm{E}-18$ & $1.00 \mathrm{E}-18$ & $1.00 \mathrm{E}-18$ \\
\hline 500 & $.00 \mathrm{E}-18$ & $1.00 \mathrm{E}-18$ & $1.00 \mathrm{E}-18$ & $1.00 \mathrm{E}-18$ & $1.00 \mathrm{E}-18$ & $1.00 \mathrm{E}-18$ & $1.00 \mathrm{E}-18$ & $1.00 \mathrm{E}-18$ & $1.00 \mathrm{E}-18$ & $1.00 \mathrm{E}-18$ & $1.00 \mathrm{E}-18$ \\
\hline 600 & $.00 \mathrm{E}-18$ & $1.00 \mathrm{E}-18$ & $1.00 \mathrm{E}-18$ & $1.00 \mathrm{E}-18$ & $1.00 \mathrm{E}-18$ & $1.00 \mathrm{E}-18$ & $1.00 \mathrm{E}-18$ & $1.00 \mathrm{E}-18$ & $1.00 \mathrm{E}-18$ & $1.00 \mathrm{E}-18$ & $1.00 \mathrm{E}-18$ \\
\hline 700 & $1.00 \mathrm{E}-18$ & $1.00 \mathrm{E}-18$ & $1.00 \mathrm{E}-18$ & $1.00 \mathrm{E}-18$ & $1.00 \mathrm{E}-18$ & $1.00 \mathrm{E}-18$ & $1.00 \mathrm{E}-18$ & $1.00 \mathrm{E}-18$ & $1.00 \mathrm{E}-18$ & $1.00 \mathrm{E}-18$ & $1.00 \mathrm{E}-18$ \\
\hline 800 & $0 \mathrm{E}-18$ & 00E-18 & $00 \mathrm{E}-18$ & 00E-18 & $.00 \mathrm{E}-18$ & E-18 & $1.00 \mathrm{E}-18$ & $1.00 \mathrm{E}-18$ & $1.00 \mathrm{E}-18$ & $1.00 \mathrm{E}-18$ & E-18 \\
\hline 900 & 00E-18 & $1.00 \mathrm{E}-18$ & $1.00 \mathrm{E}-18$ & $1.00 \mathrm{E}-18$ & $1.00 \mathrm{E}-18$ & & & & & $1.00 \mathrm{E}-18$ & \\
\hline 1000 & $3.94 \mathrm{E}-12$ & & & & & & & & & & \\
\hline 1250 & 2.08E-08 & 1.00E-18 & $1.00 \mathrm{E}-18$ & $1.00 \mathrm{E}-18$ & $1.00 \mathrm{E}-18$ & $1.00 \mathrm{E}-18$ & $1.00 \mathrm{E}-18$ & $1.00 \mathrm{E}-18$ & $1.00 \mathrm{E}-18$ & $1.00 \mathrm{E}-18$ & $1.00 \mathrm{E}-18$ \\
\hline 1500 & & $1.00 \mathrm{E}-18$ & $1.00 \mathrm{E}-18$ & 1.00E-18 & 2.57E-17 & & $1.00 \mathrm{E}-18$ & & $1.00 \mathrm{E}-18$ & $1.00 \mathrm{E}-18$ & $1.00 \mathrm{E}-18$ \\
\hline 2000 & & & & & & & & & & & \\
\hline 2500 & $1.20 \mathrm{E}-01$ & $6.20 \mathrm{E}-10$ & 4.49E-11 & $6.05 \mathrm{E}-12$ & $3.20 \mathrm{E}-10$ & & & $1.00 \mathrm{E}-18$ & $1.00 \mathrm{E}-18$ & $1.00 \mathrm{E}-18$ & \\
\hline 3000 & 3.15E-01 & 2.85E-08 & 2.06E-09 & 2.77E-10 & 1.47E-08 & $1.00 \mathrm{E}-18$ & $1.00 \mathrm{E}-18$ & $1.00 \mathrm{E}-18$ & $1.00 \mathrm{E}-18$ & $1.00 \mathrm{E}-18$ & $1.00 \mathrm{E}-18$ \\
\hline 3500 & 4.73E-01 & 2.82E-07 & $2.61 \mathrm{E}-08$ & 2.75E-09 & $1.87 \mathrm{E}-07$ & $1.00 \mathrm{E}-18$ & $1.00 \mathrm{E}-18$ & $1.00 \mathrm{E}-18$ & $1.00 \mathrm{E}-18$ & $1.00 \mathrm{E}-18$ & $1.00 \mathrm{E}-18$ \\
\hline 4000 & & & & & & & & & & & \\
\hline 4500 & & $7.20 \mathrm{E}-06$ & $5.26 \mathrm{E}-07$ & 7.05E-08 & 3.77E-06 & & $1.00 \mathrm{E}-18$ & $1.00 \mathrm{E}-18$ & $1.00 \mathrm{E}-18$ & $1.00 \mathrm{E}-18$ & $1.00 \mathrm{E}-18$ \\
\hline 5000 & 4.39E-01 & 1.73E-05 & $1.26 \mathrm{E}-06$ & $1.70 \mathrm{E}-07$ & 9.03E-06 & & $1.00 \mathrm{E}-18$ & $1.00 \mathrm{E}-18$ & $1.00 \mathrm{E}-18$ & $1.00 \mathrm{E}-18$ & $1.00 \mathrm{E}-18$ \\
\hline 6000 & $3.24 \mathrm{E}-01$ & 5.95E-05 & 4.33E-06 & $5.86 \mathrm{E}-07$ & 3.11E-05 & $1.00 \mathrm{E}-18$ & $1.00 \mathrm{E}-18$ & $1.00 \mathrm{E}-18$ & $1.00 \mathrm{E}-18$ & $1.00 \mathrm{E}-18$ & $1.00 \mathrm{E}-18$ \\
\hline 7000 & & & & & 6.96E-05 & & $1.00 \mathrm{E}-18$ & $1.00 \mathrm{E}-18$ & $1.00 \mathrm{E}-18$ & $1.00 \mathrm{E}-18$ & $1.00 \mathrm{E}-18$ \\
\hline 8000 & $2.48 \mathrm{E}-01$ & $2.34 \mathrm{E}-04$ & $1.72 \mathrm{E}-05$ & 2.32E-06 & 1.23E-04 & $1.00 \mathrm{E}-18$ & $1.00 \mathrm{E}-18$ & $1.00 \mathrm{E}-18$ & $1.00 \mathrm{E}-18$ & $1.00 \mathrm{E}-18$ & $1.00 \mathrm{E}-18$ \\
\hline 9000 & 2.19E-01 & 3.52E-04 & $2.60 \mathrm{E}-05$ & 3.49E-06 & $1.86 \mathrm{E}-04$ & $1.00 \mathrm{E}-18$ & $1.00 \mathrm{E}-18$ & $1.00 \mathrm{E}-18$ & $1.00 \mathrm{E}-18$ & $1.00 \mathrm{E}-18$ & $1.00 \mathrm{E}-18$ \\
\hline 10000 & $1.86 \mathrm{E}-01$ & 4.69E-04 & $3.44 \mathrm{E}-05$ & 4.66E-06 & $2.48 \mathrm{E}-04$ & $1.00 \mathrm{E}-18$ & $1.00 \mathrm{E}-18$ & $1.00 \mathrm{E}-18$ & $1.00 \mathrm{E}-18$ & $1.00 \mathrm{E}-18$ & $1.00 \mathrm{E}-18$ \\
\hline
\end{tabular}
Note to Table 5-5:

- $\quad 1.00 \mathrm{E}-18$ represents a zero value. 
Table 5-6. Senstivity Case \#1 Irrigation and Watering Pond

\begin{tabular}{|c|c|c|c|c|c|c|c|c|c|c|c|}
\hline \multirow{2}{*}{$\begin{array}{c}\text { Time } \\
\text { (year) }\end{array}$} & \multicolumn{11}{|c|}{ Activity Concentration $(\rho \mathrm{Ci} / \mathrm{L})$} \\
\hline & Tc-99 & $\mathrm{U}-234$ & $\mathrm{U}-235$ & $\mathrm{U}-236$ & U-238 & Am-241 & Np-237 & Pu-238 & Pu-239 & Th-228 & Th-230 \\
\hline 0 & $1.00 \mathrm{E}-18$ & $1.00 \mathrm{E}-18$ & $1.00 \mathrm{E}-18$ & $1.00 \mathrm{E}-18$ & $1.00 \mathrm{E}-18$ & $1.00 \mathrm{E}-18$ & $1.00 \mathrm{E}-18$ & $1.00 \mathrm{E}-18$ & $1.00 \mathrm{E}-18$ & $1.00 \mathrm{E}-18$ & $1.00 \mathrm{E}-18$ \\
\hline 500 & 1.00E-18 & $1.00 \mathrm{E}-18$ & 1.00E-18 & $1.00 \mathrm{E}-18$ & $1.00 \mathrm{E}-18$ & $1.00 \mathrm{E}-18$ & $1.00 \mathrm{E}-18$ & $1.00 \mathrm{E}-18$ & 1.00E-18 & $1.00 \mathrm{E}-18$ & $1.00 \mathrm{E}-18$ \\
\hline 600 & $1.00 \mathrm{E}-18$ & $1.00 \mathrm{E}-18$ & $1.00 \mathrm{E}-18$ & $1.00 \mathrm{E}-18$ & $1.00 \mathrm{E}-18$ & $1.00 \mathrm{E}-18$ & $1.00 \mathrm{E}-18$ & $1.00 \mathrm{E}-18$ & $1.00 \mathrm{E}-18$ & $1.00 \mathrm{E}-18$ & $1.00 \mathrm{E}-18$ \\
\hline 700 & $1.00 \mathrm{E}-18$ & $1.00 \mathrm{E}-18$ & $1.00 \mathrm{E}-18$ & $1.00 \mathrm{E}-18$ & $1.00 \mathrm{E}-18$ & $1.00 \mathrm{E}-18$ & $1.00 \mathrm{E}-18$ & $1.00 \mathrm{E}-18$ & $1.00 \mathrm{E}-18$ & $1.00 \mathrm{E}-18$ & $1.00 \mathrm{E}-18$ \\
\hline 800 & $5.40 \mathrm{E}-12$ & $1.00 \mathrm{E}-18$ & $1.00 \mathrm{E}-18$ & $1.00 \mathrm{E}-18$ & $1.00 \mathrm{E}-18$ & $1.00 \mathrm{E}-18$ & $1.00 \mathrm{E}-18$ & $1.00 \mathrm{E}-18$ & $1.00 \mathrm{E}-18$ & 1.00E-18 & $1.00 \mathrm{E}-18$ \\
\hline 900 & 1.12E-09 & $1.00 \mathrm{E}-18$ & $1.00 \mathrm{E}-18$ & $1.00 \mathrm{E}-18$ & $1.00 \mathrm{E}-18$ & $1.00 \mathrm{E}-18$ & $1.00 \mathrm{E}-18$ & $1.00 \mathrm{E}-18$ & $1.00 \mathrm{E}-18$ & $1.00 \mathrm{E}-18$ & $1.00 \mathrm{E}-18$ \\
\hline 1000 & 3.92E-08 & $1.00 \mathrm{E}-18$ & $1.00 \mathrm{E}-18$ & $1.00 \mathrm{E}-18$ & $1.00 \mathrm{E}-18$ & $1.00 \mathrm{E}-18$ & $1.00 \mathrm{E}-18$ & $1.00 \mathrm{E}-18$ & 1.00E-18 & 1.00E-18 & $1.00 \mathrm{E}-18$ \\
\hline 1250 & $1.07 \mathrm{E}-04$ & $1.00 \mathrm{E}-18$ & 9.05E-18 & $1.00 \mathrm{E}-18$ & 2.32E-16 & $1.00 \mathrm{E}-18$ & $1.00 \mathrm{E}-18$ & $1.00 \mathrm{E}-18$ & $1.00 \mathrm{E}-18$ & 1.00E-18 & $1.00 \mathrm{E}-18$ \\
\hline 1500 & $1.54 \mathrm{E}-02$ & 2.97E-13 & 2.47E-14 & 2.75E-15 & $1.71 \mathrm{E}-13$ & $1.00 \mathrm{E}-18$ & $1.00 \mathrm{E}-18$ & $1.00 \mathrm{E}-18$ & $1.00 \mathrm{E}-18$ & 1.00E-18 & $1.00 \mathrm{E}-18$ \\
\hline 2000 & $2.33 \mathrm{E}+00$ & 4.55E-09 & $3.08 \mathrm{E}-10$ & 4.22E-11 & 2.13E-09 & $1.00 \mathrm{E}-18$ & $1.00 \mathrm{E}-18$ & $1.00 \mathrm{E}-18$ & $1.00 \mathrm{E}-18$ & $1.00 \mathrm{E}-18$ & $1.00 \mathrm{E}-18$ \\
\hline 2500 & $9.55 \mathrm{E}+00$ & 1.11E-06 & 7.50E-08 & 1.03E-08 & 5.15E-07 & $1.00 \mathrm{E}-18$ & $1.00 \mathrm{E}-18$ & $1.00 \mathrm{E}-18$ & $1.00 \mathrm{E}-18$ & $1.00 \mathrm{E}-18$ & $1.00 \mathrm{E}-18$ \\
\hline 3000 & $1.31 \mathrm{E}+01$ & $3.21 \mathrm{E}-05$ & 2.18E-06 & 2.99E-07 & $1.51 \mathrm{E}-05$ & $1.00 \mathrm{E}-18$ & $1.00 \mathrm{E}-18$ & $1.00 \mathrm{E}-18$ & $1.00 \mathrm{E}-18$ & $1.00 \mathrm{E}-18$ & $1.00 \mathrm{E}-18$ \\
\hline 3500 & $1.45 \mathrm{E}+01$ & 2.80E-04 & $1.91 \mathrm{E}-05$ & 2.62E-06 & 1.32E-04 & $1.00 \mathrm{E}-18$ & $1.00 \mathrm{E}-18$ & $1.00 \mathrm{E}-18$ & $1.00 \mathrm{E}-18$ & $1.00 \mathrm{E}-18$ & $1.00 \mathrm{E}-18$ \\
\hline 4000 & $1.45 \mathrm{E}+01$ & $1.22 \mathrm{E}-03$ & 8.25E-05 & $1.14 \mathrm{E}-05$ & 5.75E-04 & $1.00 \mathrm{E}-18$ & $1.00 \mathrm{E}-18$ & $1.00 \mathrm{E}-18$ & $1.00 \mathrm{E}-18$ & 1.00E-18 & $1.00 \mathrm{E}-18$ \\
\hline 4500 & $1.37 \mathrm{E}+01$ & $3.38 \mathrm{E}-03$ & $2.30 \mathrm{E}-04$ & $3.16 \mathrm{E}-05$ & $1.60 \mathrm{E}-03$ & $1.00 \mathrm{E}-18$ & $1.00 \mathrm{E}-18$ & $1.00 \mathrm{E}-18$ & $1.00 \mathrm{E}-18$ & $1.00 \mathrm{E}-18$ & $1.00 \mathrm{E}-18$ \\
\hline 5000 & $1.29 \mathrm{E}+01$ & 7.10E-03 & 4.84E-04 & 6.65E-05 & 3.35E-03 & $1.00 \mathrm{E}-18$ & $1.00 \mathrm{E}-18$ & $1.00 \mathrm{E}-18$ & $1.00 \mathrm{E}-18$ & 1.00E-18 & $1.00 \mathrm{E}-18$ \\
\hline 6000 & $1.17 \mathrm{E}+01$ & 1.84E-02 & 1.26E-03 & 1.73E-04 & 8.70E-03 & $1.00 \mathrm{E}-18$ & $1.00 \mathrm{E}-18$ & $1.00 \mathrm{E}-18$ & $1.00 \mathrm{E}-18$ & $1.00 \mathrm{E}-18$ & $1.00 \mathrm{E}-18$ \\
\hline 7000 & $1.03 \mathrm{E}+01$ & 3.24E-02 & 2.22E-03 & 3.05E-04 & $1.54 \mathrm{E}-02$ & $1.00 \mathrm{E}-18$ & $1.00 \mathrm{E}-18$ & $1.00 \mathrm{E}-18$ & $1.00 \mathrm{E}-18$ & 1.00E-18 & $1.00 \mathrm{E}-18$ \\
\hline 8000 & $8.55 E+00$ & 4.66E-02 & 3.23E-03 & 4.41E-04 & 2.22E-02 & $1.00 \mathrm{E}-18$ & $1.00 \mathrm{E}-18$ & $1.00 \mathrm{E}-18$ & $1.00 \mathrm{E}-18$ & $1.00 \mathrm{E}-18$ & $1.00 \mathrm{E}-18$ \\
\hline 9000 & $6.75 \mathrm{E}+00$ & $6.00 \mathrm{E}-02$ & 4.16E-03 & 5.70E-04 & 2.88E-02 & $1.00 \mathrm{E}-18$ & $1.00 \mathrm{E}-18$ & $1.00 \mathrm{E}-18$ & $1.00 \mathrm{E}-18$ & $1.00 \mathrm{E}-18$ & $1.00 \mathrm{E}-18$ \\
\hline 10000 & $5.25 \mathrm{E}+00$ & 7.25E-02 & 5.05E-03 & $6.90 \mathrm{E}-04$ & 3.48E-02 & $1.00 \mathrm{E}-18$ & $1.00 \mathrm{E}-18$ & $1.00 \mathrm{E}-18$ & $1.00 \mathrm{E}-18$ & 1.00E-18 & $1.00 \mathrm{E}-18$ \\
\hline
\end{tabular}

Note to Table 5-6:

- $\quad 1.00 \mathrm{E}-18$ represents a zero value. 
Table 5-7. Sensitivity Case \#3 Irrigation and Watering Pond

\begin{tabular}{|c|c|c|c|c|c|c|c|c|c|c|c|}
\hline \multirow{2}{*}{$\begin{array}{c}\text { Time } \\
\text { (year) }\end{array}$} & \multicolumn{11}{|c|}{ Activity Concentration $(\rho \mathrm{Ci} / \mathrm{L})$} \\
\hline & Tc-99 & U-234 & U-235 & U-236 & U-238 & Am-241 & Np-237 & Pu-238 & Pu-239 & Th-228 & Th-230 \\
\hline 0 & 1.00E-18 & $1.00 \mathrm{E}-18$ & $1.00 \mathrm{E}-18$ & $1.00 \mathrm{E}-18$ & $1.00 \mathrm{E}-18$ & 1.00E-18 & $1.00 \mathrm{E}-18$ & $1.00 \mathrm{E}-18$ & 1.00E-18 & $1.00 \mathrm{E}-18$ & $1.00 \mathrm{E}-18$ \\
\hline 500 & $.00 \mathrm{E}-18$ & $1.00 \mathrm{E}-18$ & $1.00 \mathrm{E}-18$ & $1.00 \mathrm{E}-18$ & $1.00 \mathrm{E}-18$ & $.00 \mathrm{E}-18$ & $.00 \mathrm{E}-18$ & $1.00 \mathrm{E}-18$ & $1.00 \mathrm{E}-18$ & $1.00 \mathrm{E}-18$ & $1.00 \mathrm{E}-18$ \\
\hline 600 & $1.00 \mathrm{E}-18$ & $1.00 \mathrm{E}-18$ & $1.00 \mathrm{E}-18$ & $1.00 \mathrm{E}-18$ & $1.00 \mathrm{E}-18$ & $1.00 \mathrm{E}-18$ & $1.00 \mathrm{E}-18$ & $1.00 \mathrm{E}-18$ & $1.00 \mathrm{E}-18$ & $1.00 \mathrm{E}-18$ & $1.00 \mathrm{E}-18$ \\
\hline 700 & $1.00 \mathrm{E}-18$ & $1.00 \mathrm{E}-18$ & $1.00 \mathrm{E}-18$ & $1.00 \mathrm{E}-18$ & $1.00 \mathrm{E}-18$ & $1.00 \mathrm{E}-18$ & $1.00 \mathrm{E}-18$ & $1.00 \mathrm{E}-18$ & $1.00 \mathrm{E}-18$ & $1.00 \mathrm{E}-18$ & $1.00 \mathrm{E}-18$ \\
\hline 800 & $1.00 \mathrm{E}-18$ & $1.00 \mathrm{E}-18$ & $1.00 \mathrm{E}-18$ & 1.00E-18 & $1.00 \mathrm{E}-18$ & .00E-18 & $.00 \mathrm{E}-18$ & $1.00 \mathrm{E}-18$ & $1.00 \mathrm{E}-18$ & $1.00 \mathrm{E}-18$ & $1.00 \mathrm{E}-18$ \\
\hline 900 & $1.00 \mathrm{E}-18$ & $1.00 \mathrm{E}-18$ & $1.00 \mathrm{E}-18$ & $1.00 \mathrm{E}-18$ & $1.00 \mathrm{E}-18$ & $1.00 \mathrm{E}-18$ & $1.00 \mathrm{E}-18$ & $1.00 \mathrm{E}-18$ & $1.00 \mathrm{E}-18$ & $1.00 \mathrm{E}-18$ & $1.00 \mathrm{E}-18$ \\
\hline 1000 & $3.94 \mathrm{E}-12$ & $1.00 \mathrm{E}-18$ & $1.00 \mathrm{E}-18$ & $1.00 \mathrm{E}-18$ & 1.00E-18 & $1.00 \mathrm{E}-18$ & $1.00 \mathrm{E}-18$ & $1.00 \mathrm{E}-18$ & $1.00 \mathrm{E}-18$ & $1.00 \mathrm{E}-18$ & $1.00 \mathrm{E}-18$ \\
\hline 1250 & $.08 \mathrm{E}-08$ & $1.00 \mathrm{E}-18$ & $1.00 \mathrm{E}-18$ & $1.00 \mathrm{E}-18$ & $1.00 \mathrm{E}-18$ & $1.00 \mathrm{E}-18$ & $1.00 \mathrm{E}-18$ & $1.00 \mathrm{E}-18$ & $1.00 \mathrm{E}-18$ & $1.00 \mathrm{E}-18$ & $1.00 \mathrm{E}-18$ \\
\hline 1500 & 7.90E-06 & $1.00 \mathrm{E}-18$ & 9.15E-17 & $1.00 \mathrm{E}-18$ & $7.90 \mathrm{E}-16$ & & $1.00 \mathrm{E}-18$ & $1.00 \mathrm{E}-18$ & $1.00 \mathrm{E}-18$ & $1.00 \mathrm{E}-18$ & $1.00 \mathrm{E}-18$ \\
\hline 2000 & 8.95E-03 & 3.89E-11 & $2.81 \mathrm{E}-12$ & $3.80 \mathrm{E}-13$ & $2.02 \mathrm{E}-11$ & $1.00 \mathrm{E}-18$ & $1.00 \mathrm{E}-18$ & $1.00 \mathrm{E}-18$ & $1.00 \mathrm{E}-18$ & $1.00 \mathrm{E}-18$ & $1.00 \mathrm{E}-18$ \\
\hline 2500 & $1.20 \mathrm{E}-01$ & $1.76 \mathrm{E}-08$ & $1.27 \mathrm{E}-09$ & $1.72 \mathrm{E}-10$ & $9.10 \mathrm{E}-09$ & $1.00 \mathrm{E}-18$ & $1.00 \mathrm{E}-18$ & $1.00 \mathrm{E}-18$ & $1.00 \mathrm{E}-18$ & $1.00 \mathrm{E}-18$ & $1.00 \mathrm{E}-18$ \\
\hline 3000 & 3.15E-01 & $9.10 \mathrm{E}-07$ & $6.60 \mathrm{E}-08$ & 8.95E-09 & $4.75 \mathrm{E}-07$ & $1.00 \mathrm{E}-18$ & $1.00 \mathrm{E}-18$ & $1.00 \mathrm{E}-18$ & $1.00 \mathrm{E}-18$ & $1.00 \mathrm{E}-18$ & $1.00 \mathrm{E}-18$ \\
\hline 3500 & 4.73E-01 & $1.40 \mathrm{E}-05$ & $1.02 \mathrm{E}-06$ & $1.37 \mathrm{E}-07$ & 7.30E-06 & $1.00 \mathrm{E}-18$ & $1.00 \mathrm{E}-18$ & $1.00 \mathrm{E}-18$ & $1.00 \mathrm{E}-18$ & $1.00 \mathrm{E}-18$ & $1.00 \mathrm{E}-18$ \\
\hline 4000 & 5.32E-01 & $1.01 \mathrm{E}-04$ & 7.35E-06 & $9.90 \mathrm{E}-07$ & $5.30 \mathrm{E}-05$ & $1.00 \mathrm{E}-18$ & $1.00 \mathrm{E}-18$ & $1.00 \mathrm{E}-18$ & $1.00 \mathrm{E}-18$ & $1.00 \mathrm{E}-18$ & $1.00 \mathrm{E}-18$ \\
\hline 4500 & $5.03 \mathrm{E}-01$ & $4.36 \mathrm{E}-04$ & $3.17 \mathrm{E}-05$ & $4.29 \mathrm{E}-06$ & $2.27 \mathrm{E}-04$ & $1.00 \mathrm{E}-18$ & $1.00 \mathrm{E}-18$ & $1.00 \mathrm{E}-18$ & $1.00 \mathrm{E}-18$ & $1.00 \mathrm{E}-18$ & $1.00 \mathrm{E}-18$ \\
\hline 5000 & 4.39E-01 & $1.32 \mathrm{E}-03$ & $9.65 \mathrm{E}-05$ & 1.30E-05 & $6.90 \mathrm{E}-04$ & 1.00E-18 & $1.00 \mathrm{E}-18$ & $1.00 \mathrm{E}-18$ & $1.00 \mathrm{E}-18$ & 1.00E-18 & $1.00 \mathrm{E}-18$ \\
\hline 6000 & 3.24E-01 & $6.00 \mathrm{E}-03$ & 4.36E-04 & 5.90E-05 & $3.14 \mathrm{E}-03$ & $1.00 \mathrm{E}-18$ & $1.00 \mathrm{E}-18$ & $1.00 \mathrm{E}-18$ & $1.00 \mathrm{E}-18$ & $1.00 \mathrm{E}-18$ & $1.00 \mathrm{E}-18$ \\
\hline 7000 & 2.75E-01 & $1.52 \mathrm{E}-02$ & $1.12 \mathrm{E}-03$ & 1.51E-04 & 8.00E-03 & $1.00 \mathrm{E}-18$ & $1.00 \mathrm{E}-18$ & $1.00 \mathrm{E}-18$ & $1.00 \mathrm{E}-18$ & $1.00 \mathrm{E}-18$ & 1.00E-18 \\
\hline 8000 & 2.48E-01 & 2.83E-02 & $2.08 \mathrm{E}-03$ & 2.81E-04 & $1.49 \mathrm{E}-02$ & $1.00 \mathrm{E}-18$ & $1.00 \mathrm{E}-18$ & $1.00 \mathrm{E}-18$ & $1.00 \mathrm{E}-18$ & $1.00 \mathrm{E}-18$ & $1.00 \mathrm{E}-18$ \\
\hline 9000 & 2.19E-01 & 4.35E-02 & $3.21 \mathrm{E}-03$ & 4.33E-04 & $2.30 \mathrm{E}-02$ & $1.00 \mathrm{E}-18$ & $1.00 \mathrm{E}-18$ & $1.00 \mathrm{E}-18$ & $1.00 \mathrm{E}-18$ & $1.00 \mathrm{E}-18$ & $1.00 \mathrm{E}-18$ \\
\hline 10000 & 1.86E-01 & 5.90E-02 & $4.36 \mathrm{E}-03$ & 5.90E-04 & $3.14 \mathrm{E}-02$ & $1.00 \mathrm{E}-18$ & $1.00 \mathrm{E}-18$ & $1.00 \mathrm{E}-18$ & $1.00 \mathrm{E}-18$ & $1.00 \mathrm{E}-18$ & $1.00 \mathrm{E}-18$ \\
\hline
\end{tabular}

Note to Table 5-7:

- $\quad 1.00 \mathrm{E}-18$ represents a zero value. 
Table 5-8. Portsmouth OSWDF Decay Chains - Half-lives and Branching Fractions

\begin{tabular}{|c|c|c|c|c|c|}
\hline Radionuclide & $\begin{array}{c}\text { Half-life }{ }^{1} \\
\text { (years) }\end{array}$ & $\begin{array}{c}\text { Daughter } 1 \\
\text { Branching } \\
\text { Fraction }\end{array}$ & Daughter 1 & $\begin{array}{c}\text { Daughter } 2 \\
\text { Branching } \\
\text { Fraction } \\
\end{array}$ & Daughter 2 \\
\hline Ac-225 & $2.74 \mathrm{E}-02$ & 1 & Fr-221 & & \\
\hline Ac-227 & $2.18 \mathrm{E}+01$ & 0.9862 & Th-227 & 0.0138 & Fr223 \\
\hline Ac-228 & 7.02E-04 & 1 & Th-228 & & \\
\hline Am-241 & $4.32 E+02$ & 1 & Np-237 & & \\
\hline At-217 & 1.02E-09 & 0.99988 & Bi-213 & & \\
\hline At-218 & 4.75E-08 & 0.999 & $\mathrm{Bi}-214$ & 0.001 & Rn218 \\
\hline $\mathrm{Bi}-210$ & $1.37 \mathrm{E}-02$ & 1 & Po-210 & 2 & \\
\hline Bi-211 & 4.07E-06 & 0.99724 & Tl-207 & 0.00276 & Po211 \\
\hline Bi-212 & 1.33E-05 & 0.6406 & Po-212 & 0.3594 & Tl208 \\
\hline $\mathrm{Bi}-213$ & 8.67E-05 & 0.9791 & Po-213 & 0.0209 & Tl209 \\
\hline $\mathrm{Bi}-214$ & $3.78 \mathrm{E}-05$ & 0.99979 & Po-214 & 0.00021 & $\mathrm{Tl} 210$ \\
\hline Fr-221 & 9.32E-06 & 1 & At-217 & & \\
\hline Fr-223 & 4.18E-05 & 1 & Ra-223 & 2 & \\
\hline Np-237 & $2.14 \mathrm{E}+06$ & 1 & $\mathrm{~Pa}-233$ & & \\
\hline Pa-231 & $3.28 \mathrm{E}+04$ & 1 & Ac-227 & & \\
\hline Pa-233 & 7.38E-02 & 1 & U-233 & & \\
\hline Pa-234 & 7.64E-04 & 1 & U-234 & & \\
\hline $\mathrm{Pa}-234 \mathrm{~m}$ & 2.22E-06 & 0.9984 & $\mathrm{U}-234$ & 0.0016 & $\mathrm{~Pa} 234$ \\
\hline Pb-209 & $3.71 \mathrm{E}-04$ & 1 & $\mathrm{Bi}$ & & \\
\hline $\mathrm{Pb}-210$ & $2.22 \mathrm{E}+01$ & 1 & $\mathrm{Bi}-210$ & 2 & \\
\hline $\mathrm{Pb}-211$ & $6.86 \mathrm{E}-05$ & 1 & Bi-211 & & \\
\hline Pb-212 & $1.21 \mathrm{E}-03$ & 1 & $\mathrm{Bi}-212$ & & \\
\hline $\mathrm{Pb}-214$ & $5.10 \mathrm{E}-05$ & 1 & $\mathrm{Bi}-214$ & & \\
\hline Po-210 & 3.79E-01 & 1 & $\mathrm{~Pb}$ & & \\
\hline Po-211 & 1.64E-08 & 1 & $\mathrm{~Pb}$ & & \\
\hline Po-212 ${ }^{3}$ & $\begin{array}{r}9.47 \mathrm{E}-15 \\
(2.00 \mathrm{E}-10) \\
\end{array}$ & 1 & $\mathrm{~Pb}$ & & \\
\hline Po- $213^{3}$ & $\begin{array}{r}1.33 \mathrm{E}-13 \\
(2.00 \mathrm{E}-10)\end{array}$ & 1 & Pb-209 & & \\
\hline Po-214 3 & $\begin{array}{r}5.21 \mathrm{E}-12 \\
(2.00 \mathrm{E}-10)\end{array}$ & 1 & $\mathrm{~Pb}-210$ & & \\
\hline Po-215 3 & $\begin{array}{r}5.64 \mathrm{E}-11 \\
(2.00 \mathrm{E}-10)\end{array}$ & 1 & $\mathrm{~Pb}-211$ & & \\
\hline Po-216 & 4.59E-09 & 1 & Pb-212 & & \\
\hline Po-218 & 5.89E-06 & 0.9998 & $\mathrm{~Pb}-214$ & 0.0002 & At218 \\
\hline $\mathrm{Pu}-238$ & $8.77 \mathrm{E}+01$ & 1 & U-234 & & \\
\hline Pu-239 & $2.41 \mathrm{E}+04$ & 0.9994 & U-235m & 0.0006 & U235 \\
\hline Ra-223 & 3.13E-02 & 1 & Rn-219 & & \\
\hline Ra-224 & 1.00E-02 & 1 & Rn-220 & & \\
\hline
\end{tabular}


SRNL-STI-2014-00130

Revision 0

\begin{tabular}{|c|c|c|c|c|c|}
\hline Radionuclide & $\begin{array}{c}\text { Half-life } \\
\text { (years) }\end{array}$ & $\begin{array}{c}\text { Daughter } 1 \\
\text { Branching } \\
\text { Fraction } \\
\end{array}$ & Daughter 1 & $\begin{array}{c}\text { Daughter } 2 \\
\text { Branching } \\
\text { Fraction }\end{array}$ & Daughter 2 \\
\hline Ra-225 & 4.08E-02 & 1 & Ac-225 & & \\
\hline Ra-226 & $1.60 \mathrm{E}+03$ & 1 & $\mathrm{Rn}-222$ & & \\
\hline Ra-228 & $5.75 \mathrm{E}+00$ & 1 & Ac-228 & & \\
\hline Rn-218 & 1.11E-09 & 1 & Po-214 & & \\
\hline Rn-219 & $1.25 \mathrm{E}-07$ & 1 & Po-215 & & \\
\hline Rn-220 & 1.76E-06 & 1 & Po-216 & & \\
\hline Rn-222 & $1.05 \mathrm{E}-02$ & 1 & Po-218 & & \\
\hline Tc-99 & $2.11 \mathrm{E}+05$ & 1 & $R u$ & & \\
\hline Th-227 & $5.11 \mathrm{E}-02$ & 1 & Ra-223 & & \\
\hline Th-228 & $1.91 \mathrm{E}+00$ & 1 & Ra-224 & & \\
\hline Th-229 & $7.34 \mathrm{E}+03$ & 1 & Ra-225 & & \\
\hline Th-230 & $7.54 \mathrm{E}+04$ & 1 & Ra-226 & & \\
\hline Th-231 & $2.91 \mathrm{E}-03$ & 1 & Pa-231 & & \\
\hline Th-232 & $1.41 \mathrm{E}+10$ & 1 & Ra-228 & & \\
\hline Th-234 & $6.60 \mathrm{E}-02$ & 1 & $\mathrm{~Pa}-234 \mathrm{~m}$ & & \\
\hline Tl-207 & 9.07E-06 & 1 & $\mathrm{~Pb}$ & & \\
\hline Tl-208 & 5.80E-06 & 1 & $\mathrm{~Pb}$ & & \\
\hline Tl-209 & 4.11E-06 & 1 & Pb-209 & & \\
\hline Tl-210 & $2.47 \mathrm{E}-06$ & 1 & $\mathrm{~Pb}-210$ & & \\
\hline U-233 & $1.59 \mathrm{E}+05$ & 1 & Th-229 & & \\
\hline U-234 & $2.46 \mathrm{E}+05$ & 1 & Th-230 & & \\
\hline U-235 & $7.04 \mathrm{E}+08$ & 1 & Th-231 & & \\
\hline U-235m & 4.94E-05 & 1 & U-235 & & \\
\hline U-236 & $2.34 \mathrm{E}+07$ & 1 & Th-232 & & \\
\hline U-238 & $4.47 \mathrm{E}+09$ & 1 & Th-234 & & \\
\hline
\end{tabular}

Notes to Table 5-8:

- $\quad$ All data obtained from ICRP 2008.

1 Radionuclide decay constant $\left(\lambda_{\mathrm{i}}\right)$ calculated from half-life: $\lambda_{i}=\operatorname{Ln} 2 / t_{1 / 2}$.

2 Rounded to 1 from value greater than 0.9999; radionuclide dose from other branch insignificant (minor branching fraction less than 0.0001).

3 GoldSim (GTG 2010) does not allow the use of half-lives less than 2.00E-10 years; therefore radionuclides with half-lives less than 2.00E-10 years were set to $2.00 \mathrm{E}-10$ years.

\section{Tc99 $\longrightarrow \mathbb{R u}$}

Figure 5-1. Technetium-99 Decay to Stable Progeny 


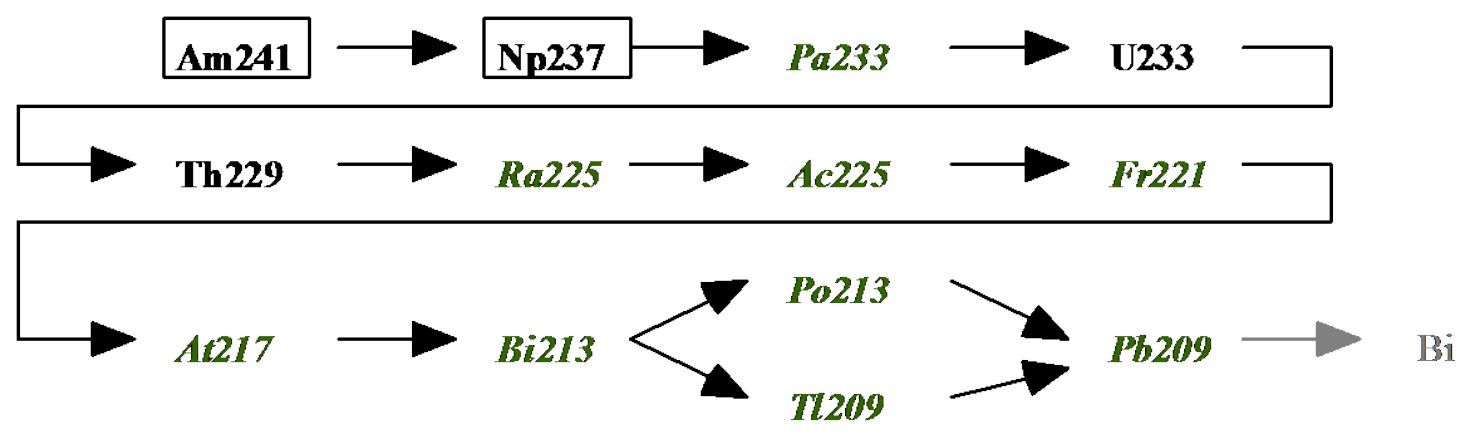

Figure 5-2. Neptunium Decay Series

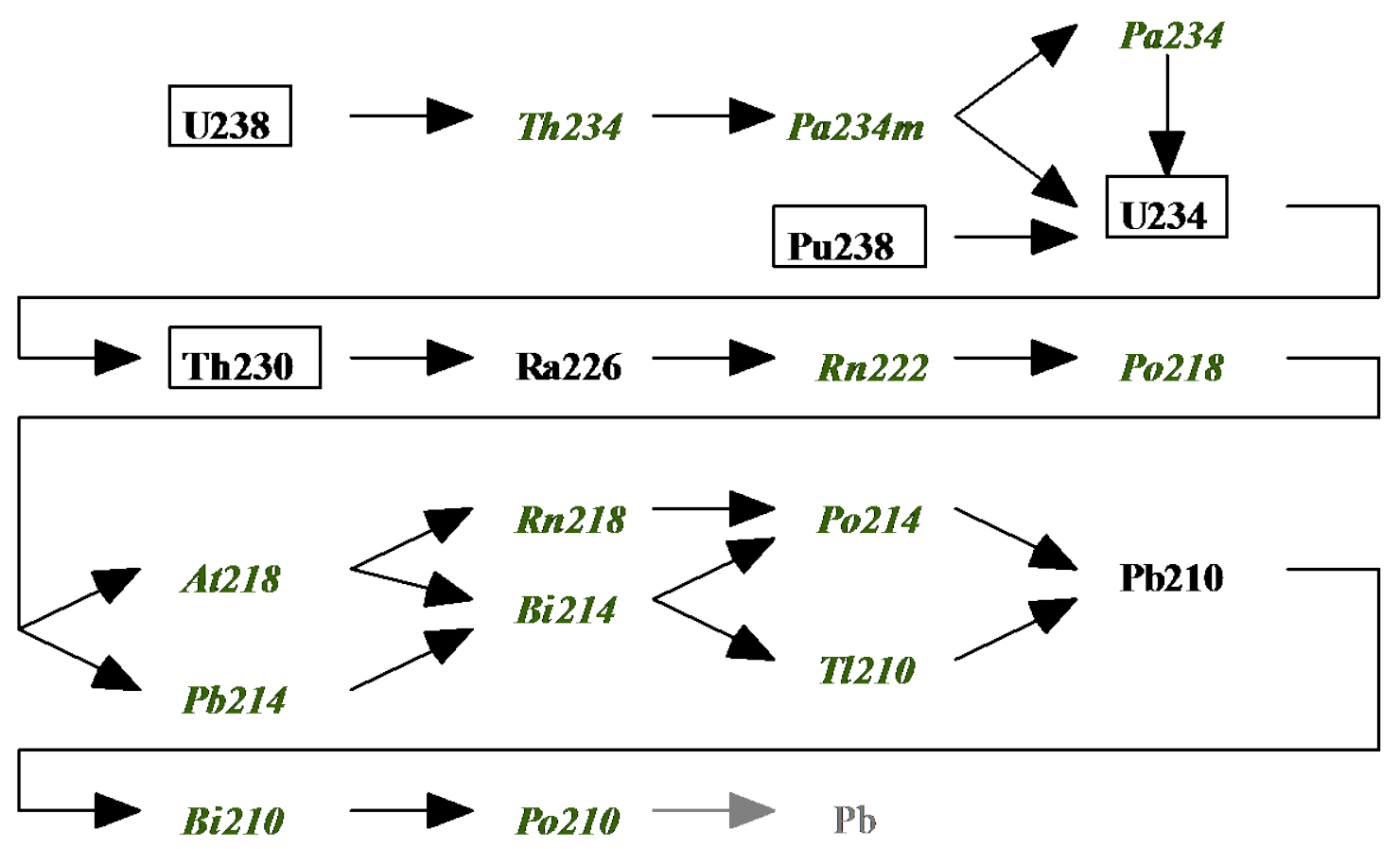

Figure 5-3. Uranium Decay Series 


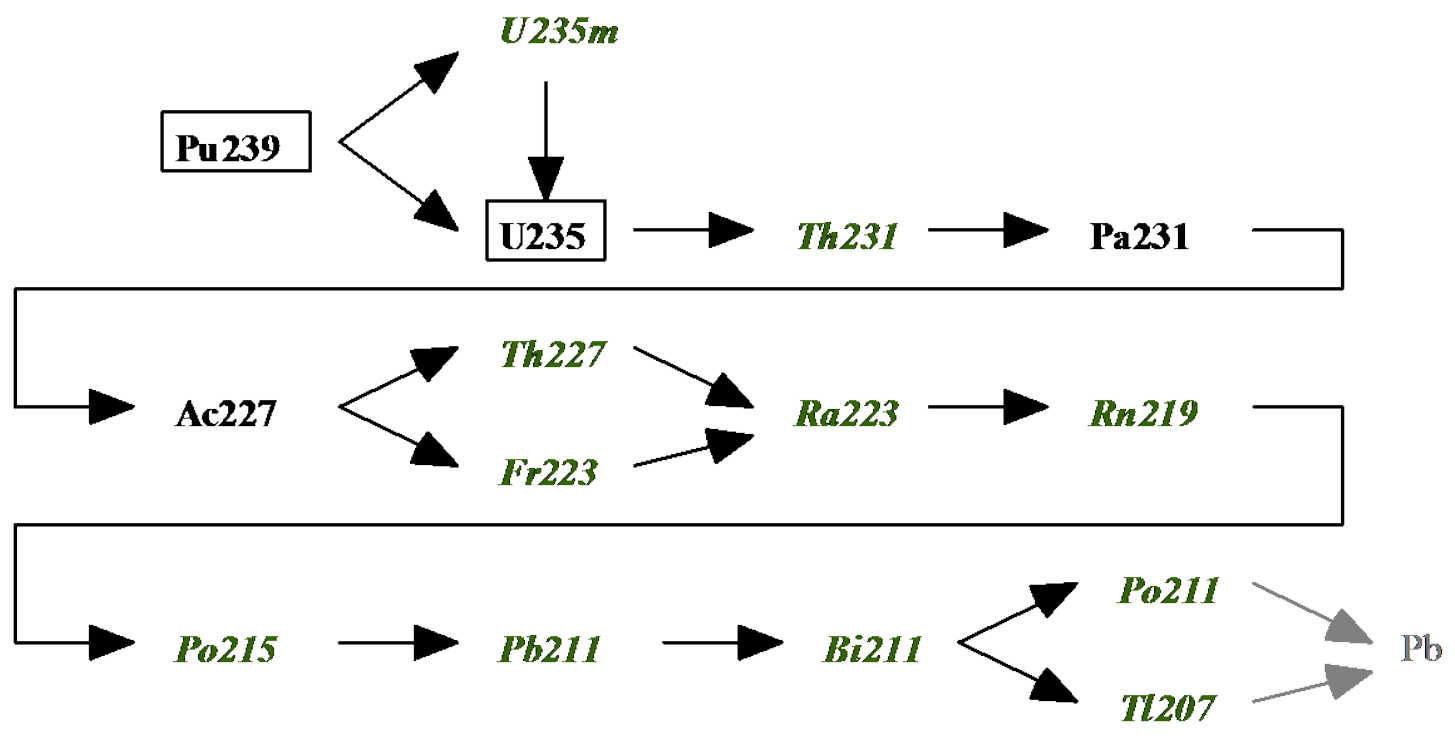

Figure 5-4. Actinium Decay Series

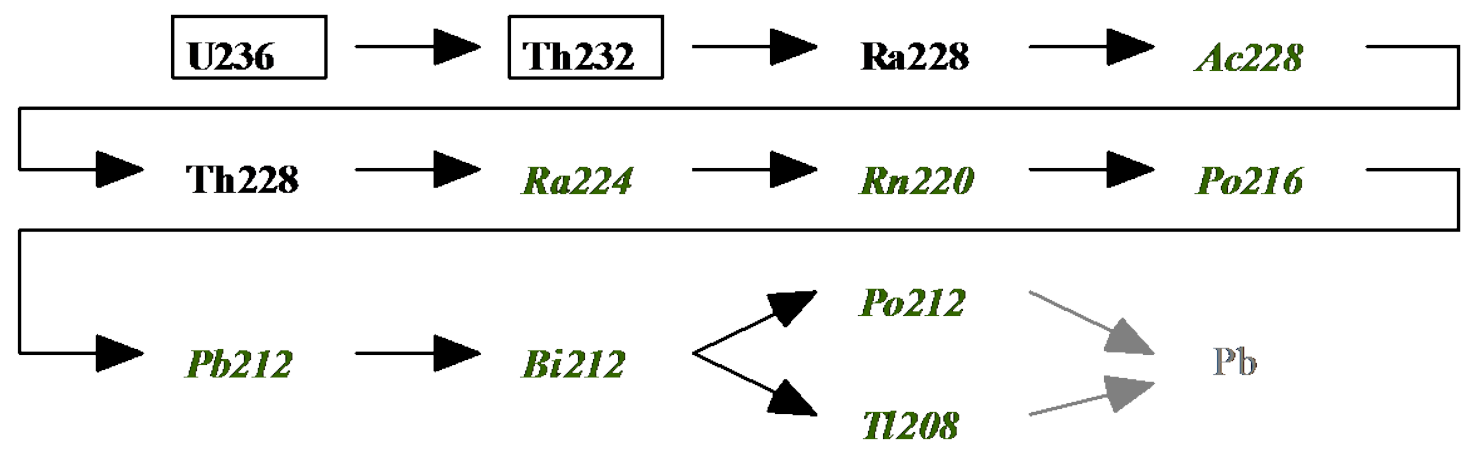

Figure 5-5. Thorium Decay Series

Notes to Figures 4-1 through 4-5:

Radionuclides in bolded black have half-lives greater than 1 year Radionuclides in bolded, italtics green have half-lives lexs than 1 year Radionuclides in a box have a starting OSWDF inventoy 
Table 5-9. Ingestion and Inhalation Dose Coefficients and External Soil Exposure Factors

\begin{tabular}{|c|c|c|c|c|c|}
\hline \multirow[t]{2}{*}{ Radionuclide } & \multicolumn{2}{|c|}{$\begin{array}{c}\text { Ingestion } \\
\text { Dose Coefficients } \\
\left(D C_{i, w}\right)^{1} \\
\end{array}$} & \multicolumn{2}{|c|}{$\begin{array}{c}\text { Inhalation } \\
\text { Dose Coefficients } \\
\left(D C_{i, a}\right)^{1,2} \\
\end{array}$} & \multirow{2}{*}{$\begin{array}{c}\text { External 15 } \\
\text { cm Soil } \\
\text { Exposure } \\
\text { Factors } \\
\left(D C_{i, e-15}\right)^{3} \\
(\text { rem/yr }) \text { per } \\
\left(\mu C \mathrm{C} / \mathrm{m}^{3}\right)\end{array}$} \\
\hline & $\mathrm{Sv} / \mathbf{B q}$ & $(\mathrm{rem} / \mu \mathrm{Ci})$ & $S v / B q$ & $(\mathrm{rem} / \mu \mathrm{Ci})$ & \\
\hline Ac-225 & 5.23E-08 & $1.94 \mathrm{E}-01$ & $9.18 \mathrm{E}-06$ & $3.40 \mathrm{E}+01$ & 3.90E-05 \\
\hline Ac-227 & 3.92E-07 & $1.45 \mathrm{E}+00$ & 5.91E-05 & $2.19 \mathrm{E}+02$ & 3.06E-07 \\
\hline Ac-228 & $5.14 \mathrm{E}-10$ & $1.90 \mathrm{E}-03$ & $1.61 \mathrm{E}-08$ & 5.96E-02 & 3.22E-03 \\
\hline Am-241 & 2.38E-07 & 8.81E-01 & $4.21 \mathrm{E}-05$ & $1.56 \mathrm{E}+02$ & 2.73E-05 \\
\hline At-217 & & & & & $1.01 \mathrm{E}-06$ \\
\hline At-218 & & & & & 3.65E-06 \\
\hline $\mathrm{Bi}-210$ & $1.80 \mathrm{E}-09$ & 6.66E-03 & $1.46 \mathrm{E}-07$ & $5.40 \mathrm{E}-01$ & 2.17E-06 \\
\hline Bi-211 & & & & & 1.49E-04 \\
\hline $\mathrm{Bi}-212$ & 3.52E-10 & $1.30 \mathrm{E}-03$ & 3.67E-08 & 1.36E-01 & $6.26 \mathrm{E}-04$ \\
\hline $\mathrm{Bi}-213$ & $2.68 \mathrm{E}-10$ & 9.92E-04 & 3.55E-08 & 1.31E-01 & 4.38E-04 \\
\hline $\mathrm{Bi}-214$ & $1.49 \mathrm{E}-10$ & $5.51 \mathrm{E}-04$ & $1.72 \mathrm{E}-08$ & $6.36 \mathrm{E}-02$ & 5.09E-03 \\
\hline Fr-221 & & & & & 9.23E-05 \\
\hline Fr-223 & 3.23E-09 & $1.20 \mathrm{E}-02$ & 1.33E-08 & 4.92E-02 & $1.18 \mathrm{E}-04$ \\
\hline Np-237 & $1.25 \mathrm{E}-07$ & 4.63E-01 & $2.30 \mathrm{E}-05$ & $8.51 \mathrm{E}+01$ & 4.86E-05 \\
\hline Pa-231 & 5.59E-07 & $2.07 \mathrm{E}+00$ & 2.99E-05 & $1.11 \mathrm{E}+02$ & 1.12E-04 \\
\hline Pa-233 & $1.32 \mathrm{E}-09$ & 4.88E-03 & 4.56E-09 & $1.69 \mathrm{E}-02$ & 6.03E-04 \\
\hline Pa-234 & 5.57E-10 & 2.06E-03 & $3.98 \mathrm{E}-10$ & $1.47 \mathrm{E}-03$ & $6.28 \mathrm{E}-03$ \\
\hline Pa-234m & & & & & 4.90E-05 \\
\hline $\mathrm{Pb}-209$ & $7.46 \mathrm{E}-11$ & $2.76 \mathrm{E}-04$ & $6.46 \mathrm{E}-11$ & 2.39E-04 & 4.76E-07 \\
\hline $\mathrm{Pb}-210$ & $1.02 \mathrm{E}-06$ & $3.77 \mathrm{E}+00$ & $1.21 \mathrm{E}-06$ & $4.48 \mathrm{E}+00$ & 1.53E-06 \\
\hline $\mathrm{Pb}-211$ & $2.62 \mathrm{E}-10$ & 9.69E-04 & $1.26 \mathrm{E}-08$ & 4.66E-02 & $1.70 \mathrm{E}-04$ \\
\hline $\mathrm{Pb}-212$ & 1.03E-08 & 3.81E-02 & $1.86 \mathrm{E}-07$ & 6.88E-01 & 4.23E-04 \\
\hline $\mathrm{Pb}-214$ & $1.99 \mathrm{E}-10$ & 7.36E-04 & $1.47 \mathrm{E}-08$ & $5.44 \mathrm{E}-02$ & 7.83E-04 \\
\hline Po-210 & $3.56 \mathrm{E}-07$ & $1.32 \mathrm{E}+00$ & $3.60 \mathrm{E}-06$ & $1.33 \mathrm{E}+01$ & $2.86 \mathrm{E}-08$ \\
\hline Po-211 & & & & & 2.62E-05 \\
\hline Po-212 & & & & & \\
\hline Po-213 & & & & & \\
\hline Рo-214 & & & & & 2.80E-07 \\
\hline Po-215 & & & & & $5.82 \mathrm{E}-07$ \\
\hline Po-216 & & & & & 5.69E-08 \\
\hline Po-218 & & & & & 3.07E-08 \\
\hline Pu-238 & 2.63E-07 & 9.73E-01 & 4.65E-05 & $1.72 \mathrm{E}+02$ & 9.43E-08 \\
\hline Pu-239 & 2.88E-07 & $1.07 \mathrm{E}+00$ & 5.04E-05 & $1.86 \mathrm{E}+02$ & 1.78E-07 \\
\hline
\end{tabular}


SRNL-STI-2014-00130

Revision 0

\begin{tabular}{|c|c|c|c|c|c|}
\hline \multirow[t]{2}{*}{ Radionuclide } & \multicolumn{2}{|c|}{$\begin{array}{c}\text { Ingestion } \\
\text { Dose Coefficients } \\
\left(D C_{i, w}\right)^{1} \\
\end{array}$} & \multicolumn{2}{|c|}{$\begin{array}{c}\text { Inhalation } \\
\text { Dose Coefficients } \\
\left(D C_{i, a}\right)^{1,2} \\
\end{array}$} & \multirow{2}{*}{$\begin{array}{c}\text { External 15 } \\
\text { cm Soil } \\
\text { Exposure } \\
\text { Factors } \\
\left(D C_{i, e-15}\right)^{3} \\
(\text { rem/yr }) \text { per } \\
\left(\mu C \mathrm{Ci} \mathrm{m}^{3}\right) \\
\end{array}$} \\
\hline & $\mathrm{Sv} / \mathbf{B q}$ & (rem/ $\mu \mathrm{Ci})$ & $\mathbf{S v} / \mathbf{B q}$ & $(\mathrm{rem} / \mu \mathrm{Ci})$ & \\
\hline Ra-223 & 2.17E-07 & 8.03E-01 & 8.05E-06 & $2.98 \mathrm{E}+01$ & $3.62 \mathrm{E}-04$ \\
\hline Ra-224 & $1.26 \mathrm{E}-07$ & 4.66E-01 & $3.22 \mathrm{E}-06$ & $1.19 \mathrm{E}+01$ & 3.06E-05 \\
\hline Ra-225 & 2.38E-07 & 8.81E-01 & 6.83E-06 & $2.53 \mathrm{E}+01$ & 6.89E-06 \\
\hline Ra-226 & $4.54 \mathrm{E}-07$ & $1.68 \mathrm{E}+00$ & 3.82E-06 & $1.41 \mathrm{E}+01$ & 1.93E-05 \\
\hline Ra-228 & $1.60 \mathrm{E}-06$ & $5.92 E+00$ & $3.08 \mathrm{E}-06$ & $1.14 \mathrm{E}+01$ & \\
\hline \multicolumn{6}{|l|}{ Rn-218 } \\
\hline Rn-219 & & & & & $1.80 \mathrm{E}-04$ \\
\hline Rn-220 & & & & & $1.28 \mathrm{E}-06$ \\
\hline Rn-222 & & & & & 1.33E-06 \\
\hline Тс-99 & $9.00 \mathrm{E}-10$ & 3.33E-03 & 4.42E-09 & $1.64 \mathrm{E}-02$ & 7.82E-08 \\
\hline Th-227 & $1.47 \mathrm{E}-08$ & $5.44 \mathrm{E}-02$ & $1.12 \mathrm{E}-05$ & $4.14 \mathrm{E}+01$ & $3.10 \mathrm{E}-04$ \\
\hline Th-228 & 1.16E-07 & 4.29E-01 & 4.35E-05 & $1.61 \mathrm{E}+02$ & 4.87E-06 \\
\hline Th-229 & $6.08 \mathrm{E}-07$ & $2.25 \mathrm{E}+00$ & 7.55E-05 & $2.79 \mathrm{E}+02$ & 1.99E-04 \\
\hline Th-230 & 2.53E-07 & 9.36E-01 & 1.47E-05 & $5.44 \mathrm{E}+01$ & $7.46 \mathrm{E}-07$ \\
\hline Th-231 & $4.62 \mathrm{E}-10$ & $1.71 \mathrm{E}-03$ & $3.78 \mathrm{E}-10$ & $1.40 \mathrm{E}-03$ & 2.27E-05 \\
\hline Th-232 & 2.78E-07 & $1.03 \mathrm{E}+00$ & $2.56 \mathrm{E}-05$ & $9.47 \mathrm{E}+01$ & $3.25 \mathrm{E}-07$ \\
\hline Th-234 & 4.68E-09 & $1.73 \mathrm{E}-02$ & 8.60E-09 & 3.18E-02 & $1.51 \mathrm{E}-05$ \\
\hline Tl-207 & & & & & 1.11E-05 \\
\hline Tl-208 & & & & & 1.13E-02 \\
\hline Tl-209 & & & & & $6.76 \mathrm{E}-03$ \\
\hline \multicolumn{6}{|l|}{ Tl-210 } \\
\hline U-233 & $6.02 \mathrm{E}-08$ & 2.23E-01 & 3.89E-06 & $1.44 \mathrm{E}+01$ & 8.46E-07 \\
\hline U-234 & $5.81 \mathrm{E}-08$ & 2.15E-01 & $3.81 \mathrm{E}-06$ & $1.41 \mathrm{E}+01$ & $2.50 \mathrm{E}-07$ \\
\hline $\mathrm{U}-235$ & $5.49 \mathrm{E}-08$ & 2.03E-01 & 3.38E-06 & $1.25 \mathrm{E}+01$ & 4.38E-04 \\
\hline U-235m & $5.82 \mathrm{E}-15$ & 2.15E-08 & $9.01 \mathrm{E}-16$ & 3.33E-09 & \\
\hline U-236 & 5.47E-08 & 2.02E-01 & 3.49E-06 & $1.29 \mathrm{E}+01$ & 1.33E-07 \\
\hline U-238 & $5.24 \mathrm{E}-08$ & $1.94 \mathrm{E}-01$ & 3.14E-06 & $1.16 \mathrm{E}+01$ & 6.45E-08 \\
\hline
\end{tabular}

Notes to Table 5-9:

1 Ingestion and Inhalation dose coefficients obtained from DOE 2011.

2 Utilized recommended default absorption type from DOE 2011 where available and slow absorption type otherwise.

3 External 15 cm Soil Exposure Factors obtained from EPA 1993 and Lee 2004. 
Table 5-10. Base Case Transfer Factors

\begin{tabular}{|c|c|c|c|c|c|}
\hline Radionuclide & $\begin{array}{c}\text { Soil-to- } \\
\text { Vegetable } \\
\text { Transfer } \\
\text { Factors } \\
\left(B_{i, v}\right)^{1} \\
\text { (unitless) }\end{array}$ & $\begin{array}{c}\text { Feed-to-Beef } \\
\text { Transfer } \\
\text { Factors } \\
\left(F_{i, b}\right)^{2} \\
(d / \mathbf{k g})\end{array}$ & $\begin{array}{c}\text { Feed-to- } \\
\text { Milk } \\
\text { Transfer } \\
\text { Factors } \\
\left(F_{i, m}\right)^{2} \\
(d / L) \\
\end{array}$ & $\begin{array}{c}\text { Feed-to- } \\
\text { Poultry } \\
\text { Transfer } \\
\text { Factors } \\
\left(F_{i, p}\right)^{3} \\
(d / k g) \\
\end{array}$ & $\begin{array}{c}\text { Feed-to-Egg } \\
\text { Transfer } \\
\text { Factors } \\
\left(F_{i, e}\right)^{3} \\
(d / \mathbf{k g})\end{array}$ \\
\hline Ac-225 & $1.51 \mathrm{E}-04$ & 4.00E-04 & $2.00 \mathrm{E}-05$ & 6.00E-03 & 4.00E-03 \\
\hline Ac-227 & $1.51 \mathrm{E}-04$ & $4.00 \mathrm{E}-04$ & 2.00E-05 & $6.00 \mathrm{E}-03$ & 4.00E-03 \\
\hline Ac-228 & $1.51 \mathrm{E}-04$ & $4.00 \mathrm{E}-04$ & 2.00E-05 & $6.00 \mathrm{E}-03$ & $4.00 \mathrm{E}-03$ \\
\hline Am-241 & $1.08 \mathrm{E}-04$ & 4.00E-05 & $1.50 \mathrm{E}-06$ & $6.00 \mathrm{E}-03$ & $3.00 \mathrm{E}-03$ \\
\hline At-217 & $6.45 \mathrm{E}-02$ & $1.00 \mathrm{E}-02$ & 1.03E-02 & & \\
\hline At-218 & $6.45 \mathrm{E}-02$ & $1.00 \mathrm{E}-02$ & 1.03E-02 & & \\
\hline Bi-210 & 2.15E-03 & 4.00E-04 & $5.00 \mathrm{E}-04$ & $9.80 \mathrm{E}-02$ & 2.60E-01 \\
\hline Bi-211 & 2.15E-03 & $4.00 \mathrm{E}-04$ & $5.00 \mathrm{E}-04$ & $9.80 \mathrm{E}-02$ & 2.60E-01 \\
\hline Bi-212 & $2.15 \mathrm{E}-03$ & $4.00 \mathrm{E}-04$ & $5.00 \mathrm{E}-04$ & $9.80 \mathrm{E}-02$ & $2.60 \mathrm{E}-01$ \\
\hline Bi-213 & $2.15 \mathrm{E}-03$ & $4.00 \mathrm{E}-04$ & $5.00 \mathrm{E}-04$ & $9.80 \mathrm{E}-02$ & $2.60 \mathrm{E}-01$ \\
\hline $\mathrm{Bi}-214$ & $2.15 \mathrm{E}-03$ & $4.00 \mathrm{E}-04$ & $5.00 \mathrm{E}-04$ & $9.80 \mathrm{E}-02$ & $2.60 \mathrm{E}-01$ \\
\hline Fr-221 & $1.29 \mathrm{E}-02$ & $2.50 \mathrm{E}-03$ & 2.06E-02 & & \\
\hline Fr-223 & $1.29 \mathrm{E}-02$ & $2.50 \mathrm{E}-03$ & 2.06E-02 & & \\
\hline Np-237 & 4.30E-03 & $1.00 \mathrm{E}-03$ & $5.00 \mathrm{E}-06$ & $6.00 \mathrm{E}-03$ & $4.00 \mathrm{E}-03$ \\
\hline Pa-231 & $1.08 \mathrm{E}-04$ & $4.47 \mathrm{E}-04$ & $5.00 \mathrm{E}-06$ & $6.00 \mathrm{E}-03$ & $4.00 \mathrm{E}-03$ \\
\hline Pa-233 & $1.08 \mathrm{E}-04$ & 4.47E-04 & $5.00 \mathrm{E}-06$ & $6.00 \mathrm{E}-03$ & $4.00 \mathrm{E}-03$ \\
\hline Pa-234 & $1.08 \mathrm{E}-04$ & 4.47E-04 & $5.00 \mathrm{E}-06$ & $6.00 \mathrm{E}-03$ & $4.00 \mathrm{E}-03$ \\
\hline Pa-234m & $1.08 \mathrm{E}-04$ & 4.47E-04 & $5.00 \mathrm{E}-06$ & $6.00 \mathrm{E}-03$ & $4.00 \mathrm{E}-03$ \\
\hline Pb-209 & 3.87E-03 & $4.00 \mathrm{E}-04$ & $2.60 \mathrm{E}-04$ & $8.00 \mathrm{E}-01$ & $1.00 \mathrm{E}+00$ \\
\hline $\mathrm{Pb}-210$ & 3.87E-03 & $4.00 \mathrm{E}-04$ & 2.60E-04 & 8.00E-01 & $1.00 \mathrm{E}+00$ \\
\hline $\mathrm{Pb}-211$ & 3.87E-03 & $4.00 \mathrm{E}-04$ & 2.60E-04 & 8.00E-01 & $1.00 \mathrm{E}+00$ \\
\hline $\mathrm{Pb}-212$ & 3.87E-03 & $4.00 \mathrm{E}-04$ & $2.60 \mathrm{E}-04$ & $8.00 \mathrm{E}-01$ & $1.00 \mathrm{E}+00$ \\
\hline $\mathrm{Pb}-214$ & 3.87E-03 & $4.00 \mathrm{E}-04$ & $2.60 \mathrm{E}-04$ & $8.00 \mathrm{E}-01$ & $1.00 \mathrm{E}+00$ \\
\hline Po-210 & $1.72 \mathrm{E}-04$ & $5.00 \mathrm{E}-03$ & $3.40 \mathrm{E}-04$ & & \\
\hline Po-211 & $1.72 \mathrm{E}-04$ & $5.00 \mathrm{E}-03$ & $3.40 \mathrm{E}-04$ & & \\
\hline Po-212 & $1.72 \mathrm{E}-04$ & $5.00 \mathrm{E}-03$ & $3.40 \mathrm{E}-04$ & & \\
\hline Po-213 & $1.72 \mathrm{E}-04$ & $5.00 \mathrm{E}-03$ & $3.40 \mathrm{E}-04$ & & \\
\hline Po-214 & $1.72 \mathrm{E}-04$ & $5.00 \mathrm{E}-03$ & $3.40 \mathrm{E}-04$ & & \\
\hline Po-215 & $1.72 \mathrm{E}-04$ & $5.00 \mathrm{E}-03$ & $3.40 \mathrm{E}-04$ & & \\
\hline Po-216 & $1.72 \mathrm{E}-04$ & $5.00 \mathrm{E}-03$ & $3.40 \mathrm{E}-04$ & & \\
\hline Po-218 & $1.72 \mathrm{E}-04$ & $5.00 \mathrm{E}-03$ & $3.40 \mathrm{E}-04$ & & \\
\hline $\mathrm{Pu}-238$ & $1.94 \mathrm{E}-05$ & $1.00 \mathrm{E}-05$ & $1.10 \mathrm{E}-06$ & $3.00 \mathrm{E}-03$ & $1.20 \mathrm{E}-03$ \\
\hline Pu-239 & $1.94 \mathrm{E}-05$ & $1.00 \mathrm{E}-05$ & $1.10 \mathrm{E}-06$ & $3.00 \mathrm{E}-03$ & $1.20 \mathrm{E}-03$ \\
\hline
\end{tabular}




\begin{tabular}{|c|c|c|c|c|c|}
\hline Radionuclide & $\begin{array}{c}\text { Soil-to- } \\
\text { Vegetable } \\
\text { Transfer } \\
\text { Factors } \\
\left(B_{i, v}\right)^{1} \\
\text { (unitless) }\end{array}$ & $\begin{array}{c}\text { Feed-to-Beef } \\
\text { Transfer } \\
\text { Factors } \\
\left(F_{i, b}\right)^{2} \\
(d / \mathbf{k g})\end{array}$ & $\begin{array}{c}\text { Feed-to- } \\
\text { Milk } \\
\text { Transfer } \\
\text { Factors } \\
\left(F_{i, m}\right)^{2} \\
(d / L)\end{array}$ & $\begin{array}{c}\text { Feed-to- } \\
\text { Poultry } \\
\text { Transfer } \\
\text { Factors } \\
\left(F_{i, p}\right)^{3} \\
(d / k g)\end{array}$ & $\begin{array}{c}\text { Feed-to-Egg } \\
\text { Transfer } \\
\text { Factors } \\
\left(F_{i, e}\right)^{3} \\
(d / k g)\end{array}$ \\
\hline Ra-223 & $6.45 \mathrm{E}-03$ & 9.00E-04 & $1.30 \mathrm{E}-03$ & 3.00E-02 & 3.10E-01 \\
\hline Ra-224 & $6.45 \mathrm{E}-03$ & $9.00 \mathrm{E}-04$ & $1.30 \mathrm{E}-03$ & 3.00E-02 & 3.10E-01 \\
\hline Ra-225 & $6.45 \mathrm{E}-03$ & $9.00 \mathrm{E}-04$ & $1.30 \mathrm{E}-03$ & $3.00 \mathrm{E}-02$ & 3.10E-01 \\
\hline Ra-226 & $6.45 \mathrm{E}-03$ & $9.00 \mathrm{E}-04$ & $1.30 \mathrm{E}-03$ & 3.00E-02 & $3.10 \mathrm{E}-01$ \\
\hline Ra-228 & $6.45 \mathrm{E}-03$ & $9.00 \mathrm{E}-04$ & $1.30 \mathrm{E}-03$ & 3.00E-02 & 3.10E-01 \\
\hline \multicolumn{6}{|l|}{ Rn-218 } \\
\hline \multicolumn{6}{|l|}{ Rn-219 } \\
\hline \multicolumn{6}{|l|}{$\mathrm{Rn}-220$} \\
\hline \multicolumn{6}{|l|}{ Rn-222 } \\
\hline Tc-99 & $6.45 \mathrm{E}-01$ & 6.32E-03 & $1.87 \mathrm{E}-03$ & 3.00E-02 & $3.00 \mathrm{E}+00$ \\
\hline Th-227 & 3.66E-05 & 4.00E-05 & 5.00E-06 & $6.00 \mathrm{E}-03$ & $4.00 \mathrm{E}-03$ \\
\hline Th-228 & $3.66 \mathrm{E}-05$ & $4.00 \mathrm{E}-05$ & $5.00 \mathrm{E}-06$ & $6.00 \mathrm{E}-03$ & $4.00 \mathrm{E}-03$ \\
\hline Th-229 & 3.66E-05 & 4.00E-05 & $5.00 \mathrm{E}-06$ & $6.00 \mathrm{E}-03$ & $4.00 \mathrm{E}-03$ \\
\hline Th-230 & 3.66E-05 & 4.00E-05 & $5.00 \mathrm{E}-06$ & $6.00 \mathrm{E}-03$ & $4.00 \mathrm{E}-03$ \\
\hline Th-231 & 3.66E-05 & 4.00E-05 & $5.00 \mathrm{E}-06$ & $6.00 \mathrm{E}-03$ & 4.00E-03 \\
\hline Th-232 & 3.66E-05 & $4.00 \mathrm{E}-05$ & $5.00 \mathrm{E}-06$ & $6.00 \mathrm{E}-03$ & 4.00E-03 \\
\hline Th-234 & $3.66 \mathrm{E}-05$ & $4.00 \mathrm{E}-05$ & $5.00 \mathrm{E}-06$ & $6.00 \mathrm{E}-03$ & $4.00 \mathrm{E}-03$ \\
\hline Tl-207 & $1.72 \mathrm{E}-04$ & 4.00E-02 & 2.00E-03 & & \\
\hline Tl-208 & $1.72 \mathrm{E}-04$ & $4.00 \mathrm{E}-02$ & $2.00 \mathrm{E}-03$ & & \\
\hline Tl-209 & $1.72 \mathrm{E}-04$ & 4.00E-02 & $2.00 \mathrm{E}-03$ & & \\
\hline Tl-210 & 1.72E-04 & 4.00E-02 & $2.00 \mathrm{E}-03$ & & \\
\hline U-233 & $1.72 \mathrm{E}-03$ & $3.00 \mathrm{E}-04$ & $4.00 \mathrm{E}-04$ & $7.50 \mathrm{E}-01$ & $1.10 \mathrm{E}+00$ \\
\hline U-234 & $1.72 \mathrm{E}-03$ & 3.00E-04 & $4.00 \mathrm{E}-04$ & 7.50E-01 & $1.10 \mathrm{E}+00$ \\
\hline U-235 & $1.72 \mathrm{E}-03$ & $3.00 \mathrm{E}-04$ & $4.00 \mathrm{E}-04$ & 7.50E-01 & $1.10 \mathrm{E}+00$ \\
\hline U-235m & $1.72 \mathrm{E}-03$ & $3.00 \mathrm{E}-04$ & $4.00 \mathrm{E}-04$ & 7.50E-01 & $1.10 \mathrm{E}+00$ \\
\hline U-236 & $1.72 \mathrm{E}-03$ & $3.00 \mathrm{E}-04$ & $4.00 \mathrm{E}-04$ & $7.50 \mathrm{E}-01$ & $1.10 \mathrm{E}+00$ \\
\hline U-238 & $1.72 \mathrm{E}-03$ & $3.00 \mathrm{E}-04$ & $4.00 \mathrm{E}-04$ & $7.50 \mathrm{E}-01$ & $1.10 \mathrm{E}+00$ \\
\hline
\end{tabular}

Notes to Table 5-10:

1 Soil-to-Vegetable Transfer Factors obtained from Baes et al. (1984) and Lee 2004.

Feed-to-Meat and Feed-to-Milk Transfer Factors obtained from Lee and Coffield 2008a.

3 Feed-to-Poultry and Feed-to-Egg Transfer Factors obtained from SRR 2012, which utilized values from the following sources: 1) Jannik et al. 2010; 2) PNNL 2003; and 3) IAEA 2010. 
Table 5-11. Sensitivity Case \#4 Transfer Factors

\begin{tabular}{|c|c|c|c|c|c|}
\hline Radionuclide & $\begin{array}{c}\text { Soil-to- } \\
\text { Vegetable } \\
\text { Transfer } \\
\text { Factors } \\
\left(B_{i, v}\right)^{1} \\
\text { (unitless) }\end{array}$ & $\begin{array}{c}\text { Feed-to-Beef } \\
\text { Transfer } \\
\text { Factors } \\
\left(F_{i, b}\right)^{2} \\
(d / k g) \\
\end{array}$ & $\begin{array}{c}\text { Feed-to- } \\
\text { Milk } \\
\text { Transfer } \\
\text { Factors } \\
\left(F_{i, m}\right)^{2} \\
(d / L) \\
\end{array}$ & $\begin{array}{c}\text { Feed-to- } \\
\text { Poultry } \\
\text { Transfer } \\
\text { Factors } \\
\left(F_{i, p}\right)^{3} \\
(d / k g) \\
\end{array}$ & $\begin{array}{c}\text { Feed-to-Egg } \\
\text { Transfer } \\
\text { Factors } \\
\left(F_{i, e}\right)^{3} \\
(d / \mathbf{k g}) \\
\end{array}$ \\
\hline Ac-225 & $6.11 \mathrm{E}-05$ & $4.00 \mathrm{E}-04$ & $2.00 \mathrm{E}-05$ & $6.00 \mathrm{E}-03$ & 4.00E-03 \\
\hline Ac-227 & $6.11 \mathrm{E}-05$ & $4.00 \mathrm{E}-04$ & $2.00 \mathrm{E}-05$ & $6.00 \mathrm{E}-03$ & $4.00 \mathrm{E}-03$ \\
\hline Ac-228 & $6.11 \mathrm{E}-05$ & $4.00 \mathrm{E}-04$ & $2.00 \mathrm{E}-05$ & $6.00 \mathrm{E}-03$ & $4.00 \mathrm{E}-03$ \\
\hline Am-241 & 7.33E-05 & $5.00 \mathrm{E}-04$ & $4.20 \mathrm{E}-07$ & 6.00E-03 & $3.00 \mathrm{E}-03$ \\
\hline At-217 & 2.93E-02 & $1.00 \mathrm{E}-02$ & 1.03E-02 & & \\
\hline At-218 & 2.93E-02 & $1.00 \mathrm{E}-02$ & 1.03E-02 & & \\
\hline $\mathrm{Bi}-210$ & 9.75E-02 & $4.00 \mathrm{E}-04$ & $5.00 \mathrm{E}-04$ & $9.80 \mathrm{E}-02$ & 2.60E-01 \\
\hline $\mathrm{Bi}-211$ & $9.75 \mathrm{E}-02$ & $4.00 \mathrm{E}-04$ & $5.00 \mathrm{E}-04$ & $9.80 \mathrm{E}-02$ & $2.60 \mathrm{E}-01$ \\
\hline $\mathrm{Bi}-212$ & 9.75E-02 & $4.00 \mathrm{E}-04$ & $5.00 \mathrm{E}-04$ & $9.80 \mathrm{E}-02$ & $2.60 \mathrm{E}-01$ \\
\hline Bi-213 & 9.75E-02 & $4.00 \mathrm{E}-04$ & $5.00 \mathrm{E}-04$ & $9.80 \mathrm{E}-02$ & 2.60E-01 \\
\hline Bi-214 & $9.75 \mathrm{E}-02$ & $4.00 \mathrm{E}-04$ & $5.00 \mathrm{E}-04$ & $9.80 \mathrm{E}-02$ & $2.60 \mathrm{E}-01$ \\
\hline Fr-221 & 5.85E-03 & $2.50 \mathrm{E}-03$ & $2.06 \mathrm{E}-02$ & & \\
\hline Fr-223 & 5.85E-03 & $2.50 \mathrm{E}-03$ & $2.06 \mathrm{E}-02$ & & \\
\hline Np-237 & $3.91 \mathrm{E}-03$ & $1.00 \mathrm{E}-03$ & $5.00 \mathrm{E}-06$ & $6.00 \mathrm{E}-03$ & $4.00 \mathrm{E}-03$ \\
\hline $\mathrm{Pa}-231$ & $6.11 \mathrm{E}-05$ & 4.47E-04 & $5.00 \mathrm{E}-06$ & $6.00 \mathrm{E}-03$ & $4.00 \mathrm{E}-03$ \\
\hline $\mathrm{Pa}-233$ & $6.11 \mathrm{E}-05$ & 4.47E-04 & $5.00 \mathrm{E}-06$ & $6.00 \mathrm{E}-03$ & $4.00 \mathrm{E}-03$ \\
\hline Pa-234 & $6.11 \mathrm{E}-05$ & 4.47E-04 & $5.00 \mathrm{E}-06$ & $6.00 \mathrm{E}-03$ & $4.00 \mathrm{E}-03$ \\
\hline Pa-234m & $6.11 \mathrm{E}-05$ & 4.47E-04 & $5.00 \mathrm{E}-06$ & $6.00 \mathrm{E}-03$ & $4.00 \mathrm{E}-03$ \\
\hline Pb-209 & $5.18 \mathrm{E}-03$ & $7.00 \mathrm{E}-04$ & $1.90 \mathrm{E}-04$ & $8.00 \mathrm{E}-01$ & $1.00 \mathrm{E}+00$ \\
\hline $\mathrm{Pb}-210$ & $5.18 \mathrm{E}-03$ & $7.00 \mathrm{E}-04$ & $1.90 \mathrm{E}-04$ & $8.00 \mathrm{E}-01$ & $1.00 \mathrm{E}+00$ \\
\hline $\mathrm{Pb}-211$ & $5.18 \mathrm{E}-03$ & $7.00 \mathrm{E}-04$ & $1.90 \mathrm{E}-04$ & 8.00E-01 & $1.00 \mathrm{E}+00$ \\
\hline $\mathrm{Pb}-212$ & $5.18 \mathrm{E}-03$ & 7.00E-04 & $1.90 \mathrm{E}-04$ & $8.00 \mathrm{E}-01$ & $1.00 \mathrm{E}+00$ \\
\hline Pb-214 & $5.18 \mathrm{E}-03$ & $7.00 \mathrm{E}-04$ & $1.90 \mathrm{E}-04$ & 8.00E-01 & $1.00 \mathrm{E}+00$ \\
\hline Po-210 & $4.30 \mathrm{E}-04$ & $5.00 \mathrm{E}-03$ & $2.10 \mathrm{E}-04$ & & \\
\hline Po-211 & $4.30 \mathrm{E}-04$ & $5.00 \mathrm{E}-03$ & $2.10 \mathrm{E}-04$ & & \\
\hline Po-212 & 4.30E-04 & $5.00 \mathrm{E}-03$ & $2.10 \mathrm{E}-04$ & & \\
\hline Po-213 & 4.30E-04 & $5.00 \mathrm{E}-03$ & $2.10 \mathrm{E}-04$ & & \\
\hline Po-214 & $4.30 \mathrm{E}-04$ & $5.00 \mathrm{E}-03$ & $2.10 \mathrm{E}-04$ & & \\
\hline Po-215 & $4.30 \mathrm{E}-04$ & $5.00 \mathrm{E}-03$ & $2.10 \mathrm{E}-04$ & & \\
\hline Po-216 & $4.30 \mathrm{E}-04$ & $5.00 \mathrm{E}-03$ & $2.10 \mathrm{E}-04$ & & \\
\hline Po-218 & $4.30 \mathrm{E}-04$ & $5.00 \mathrm{E}-03$ & $2.10 \mathrm{E}-04$ & & \\
\hline Pu-238 & 1.97E-05 & $1.10 \mathrm{E}-06$ & $1.00 \mathrm{E}-05$ & $3.00 \mathrm{E}-03$ & $1.20 \mathrm{E}-03$ \\
\hline Pu-239 & $1.97 \mathrm{E}-05$ & $1.10 \mathrm{E}-06$ & $1.00 \mathrm{E}-05$ & $3.00 \mathrm{E}-03$ & $1.20 \mathrm{E}-03$ \\
\hline
\end{tabular}




\begin{tabular}{|c|c|c|c|c|c|}
\hline Radionuclide & $\begin{array}{c}\text { Soil-to- } \\
\text { Vegetable } \\
\text { Transfer } \\
\text { Factors } \\
\left(B_{i, v}\right)^{1} \\
\text { (unitless) }\end{array}$ & $\begin{array}{c}\text { Feed-to-Beef } \\
\text { Transfer } \\
\text { Factors } \\
\left(F_{i, b}\right)^{2} \\
(d / k g)\end{array}$ & $\begin{array}{c}\text { Feed-to- } \\
\text { Milk } \\
\text { Transfer } \\
\text { Factors } \\
\left(F_{i, m}\right)^{2} \\
(d / L) \\
\end{array}$ & $\begin{array}{c}\text { Feed-to- } \\
\text { Poultry } \\
\text { Transfer } \\
\text { Factors } \\
\left(F_{i, p}\right)^{3} \\
(d / k g)\end{array}$ & $\begin{array}{c}\text { Feed-to-Egg } \\
\text { Transfer } \\
\text { Factors } \\
\left(F_{i, e}\right)^{3} \\
(d / k g)\end{array}$ \\
\hline Ra-223 & 1.19E-02 & $1.70 \mathrm{E}-03$ & 3.80E-04 & 3.00E-02 & 3.10E-01 \\
\hline Ra-224 & 1.19E-02 & 1.70E-03 & 3.80E-04 & 3.00E-02 & 3.10E-01 \\
\hline Ra-225 & 1.19E-02 & $1.70 \mathrm{E}-03$ & 3.80E-04 & 3.00E-02 & 3.10E-01 \\
\hline Ra-226 & 1.19E-02 & $1.70 \mathrm{E}-03$ & 3.80E-04 & 3.00E-02 & 3.10E-01 \\
\hline Ra-228 & 1.19E-02 & $1.70 \mathrm{E}-03$ & $3.80 \mathrm{E}-04$ & 3.00E-02 & $3.10 \mathrm{E}-01$ \\
\hline \multicolumn{6}{|l|}{ Rn-218 } \\
\hline \multicolumn{6}{|l|}{ Rn-219 } \\
\hline \multicolumn{6}{|l|}{ Rn-220 } \\
\hline \multicolumn{6}{|l|}{ Rn-222 } \\
\hline Tc-99 & $1.79 \mathrm{E}+01$ & 6.32E-03 & $1.87 \mathrm{E}-03$ & 3.00E-02 & $3.00 \mathrm{E}+00$ \\
\hline Th-227 & 3.14E-04 & 2.30E-04 & 5.00E-06 & 6.00E-03 & 4.00E-03 \\
\hline Th-228 & 3.14E-04 & 2.30E-04 & 5.00E-06 & 6.00E-03 & 4.00E-03 \\
\hline Th-229 & $3.14 \mathrm{E}-04$ & 2.30E-04 & 5.00E-06 & 6.00E-03 & 4.00E-03 \\
\hline Th-230 & 3.14E-04 & 2.30E-04 & 5.00E-06 & 6.00E-03 & 4.00E-03 \\
\hline Th-231 & $3.14 \mathrm{E}-04$ & $2.30 \mathrm{E}-04$ & 5.00E-06 & $6.00 \mathrm{E}-03$ & $4.00 \mathrm{E}-03$ \\
\hline Th-232 & 3.14E-04 & 2.30E-04 & 5.00E-06 & 6.00E-03 & 4.00E-03 \\
\hline Th-234 & 3.14E-04 & 2.30E-04 & 5.00E-06 & 6.00E-03 & 4.00E-03 \\
\hline Tl-207 & 2.43E-04 & 4.00E-02 & 2.00E-03 & & \\
\hline Tl-208 & 2.43E-04 & 4.00E-02 & $2.00 \mathrm{E}-03$ & & \\
\hline Tl-209 & 2.43E-04 & 4.00E-02 & 2.00E-03 & & \\
\hline Tl-210 & 2.43E-04 & 4.00E-02 & 2.00E-03 & & \\
\hline U-233 & 6.69E-03 & 3.90E-04 & $1.80 \mathrm{E}-03$ & 7.50E-01 & $1.10 \mathrm{E}+00$ \\
\hline U-234 & 6.69E-03 & 3.90E-04 & 1.80E-03 & 7.50E-01 & $1.10 \mathrm{E}+00$ \\
\hline U-235 & 6.69E-03 & 3.90E-04 & $1.80 \mathrm{E}-03$ & $7.50 \mathrm{E}-01$ & $1.10 \mathrm{E}+00$ \\
\hline U-235m & 6.69E-03 & 3.90E-04 & $1.80 \mathrm{E}-03$ & 7.50E-01 & $1.10 \mathrm{E}+00$ \\
\hline $\mathrm{U}-236$ & 6.69E-03 & $3.90 \mathrm{E}-04$ & 1.80E-03 & 7.50E-01 & $1.10 \mathrm{E}+00$ \\
\hline U-238 & 6.69E-03 & 3.90E-04 & $1.80 \mathrm{E}-03$ & $7.50 \mathrm{E}-01$ & $1.10 \mathrm{E}+00$ \\
\hline
\end{tabular}

Notes to Table 5-11:

1 Soil-to-Vegetable Transfer Factors obtained from Jannik et al. 2010, which utilized values from the following sources in order of priority: 1) IAEA 2010; 2) PNNL 2003; and 3) Lee and Coffield 2008a.

2 Feed-to-Meat and Feed-to-Milk Transfer Factors obtained from Jannik et al. 2010, which utilized values from the following sources in order of priority: 1) IAEA 2010; and 2) Lee and Coffield 2008a.

3 Feed-to-Poultry and Feed-to-Egg Transfer Factors obtained from SRR 2012, which utilized values from the following sources: 1) Jannik et al. 2010; 2) PNNL 2003; and 3) IAEA 2010. 
Table 5-12. Exposure Parameters

\begin{tabular}{|c|c|c|c|c|c|}
\hline $\begin{array}{l}\text { Exposure } \\
\text { Parameter }\end{array}$ & Exposure Parameter Definition & Units & $\begin{array}{l}\text { Typical } \\
\text { Person }\end{array}$ & $\begin{array}{l}\text { Reference } \\
\text { Person }^{2}\end{array}$ & Reference \\
\hline \multicolumn{6}{|c|}{ Ingestion of Berea Groundwater Exposure Parameters } \\
\hline$U_{w}$ & $\begin{array}{l}\text { age-adjusted human consumption rate of water } \\
\text { (1.8 L/day at } 350 \text { days/yr) }\end{array}$ & L/yr & 630 & 630 & $\begin{array}{l}\text { FBP } 2013 \text { App. B Table } \\
4\end{array}$ \\
\hline \multicolumn{6}{|c|}{ Ingestion of Vegetables Exposure Parameters } \\
\hline$f_{v}$ & fraction of vegetables from contaminated garden & unitless & 0.308 & 1 & Jannik et al., 2010 \\
\hline$U_{V}$ & human consumption rate of other vegetables & $\mathrm{kg} / \mathrm{yr}$ & 89 & 289 & Stone \& Jannik, 2013 \\
\hline$U_{L}$ & human consumption rate of leafy vegetable & $\mathrm{kg} / \mathrm{yr}$ & 11 & 31 & Stone \& Jannik, 2013 \\
\hline$f_{p}$ & $\begin{array}{l}\text { fraction of material deposited on plant surface that } \\
\text { is retained after washing (applies only to leafy } \\
\text { vegetables) }\end{array}$ & unitless & 0.5 & 0.5 & Ng et al., 1979 \\
\hline$I$ & irrigation rate (total 18.7 in applied over 56 days) & $\mathrm{L} / \mathrm{d} / \mathrm{m}^{2}$ & 8.5 & 8.5 & USDA 1970 \\
\hline$f_{\text {irr }}$ & $\begin{array}{l}\text { fraction of year vegetables and pasture grass } \\
\text { (fodder) are irrigated ( } 56 \text { days/yr) }\end{array}$ & unitless & 0.153 & 0.153 & USDA 1970 \\
\hline$t_{v}$ & harvest to consumption time for vegetables & $\mathrm{d}$ & 6 & 1 & Jannik et al., 2010 \\
\hline$R$ & $\begin{array}{l}\text { fraction of material deposited on plant surface that } \\
\text { is retained (i.e., accounts for plant runoff during } \\
\text { and immediately following irrigation) }\end{array}$ & unitless & 0.25 & 0.25 & Jannik et al., 2010 \\
\hline$t_{\text {irr }}$ & $\begin{array}{l}\text { vegetable crop and pasture grass (fodder) } \\
\text { irrigation duration (total } 18.7 \text { in applied at } 1 \text { in } \\
\text { over } 3 \text { days) }\end{array}$ & d & 56 & 56 & USDA 1970 \\
\hline \multirow[t]{3}{*}{$Y_{v p q}$} & vegetable production yield & & & & \\
\hline & - pasture grass (fodder) & $\mathrm{kg} / \mathrm{m}^{2}$ & 0.7 & 0.7 & Jannik et al., 2010 \\
\hline & - vegetable crop & $\mathrm{kg} / \mathrm{m}^{2}$ & 2.2 & 2.2 & Jannik et al., 2010 \\
\hline$\lambda_{w}$ & weathering constant & $1 / \mathrm{d}$ & 0.0495 & 0.0495 & Jannik et al., 2010 \\
\hline$t_{s}$ & $\begin{array}{l}\text { buildup time of radionuclides in soil ( } 25 \text { years } \\
\text { representing the typical amount of time a garden } \\
\text { or pasture would be used) }\end{array}$ & $\mathrm{d}$ & 9125 & 9125 & Jannik et al., 2010 \\
\hline$\rho_{s}$ & soil areal density & $\mathrm{kg} / \mathrm{m}^{2}$ & 240 & 240 & Lee and Coffield 2008b \\
\hline$P$ & precipitation rate (39.52 in/yr) & $\mathrm{L} / \mathrm{d} / \mathrm{m}^{2}$ & 2.75 & 2.75 & FBP 2014a Table I.8 \\
\hline$E$ & evapotranspiration rate (27.74 in/yr) & $\mathrm{L} / \mathrm{d} / \mathrm{m}^{2}$ & 1.93 & 1.93 & FBP 2014a Table I.8 \\
\hline$d_{g}$ & depth of garden (assumed to be $15 \mathrm{~cm}$ ) & in & 5.9 & 5.9 & Jannik et al., 2010 \\
\hline$\theta_{w}$ & volumetric water content of soil & unitless & 0.3 & 0.3 & FBP 2013 App. B Table \\
\hline
\end{tabular}




\begin{tabular}{|c|c|c|c|c|c|}
\hline $\begin{array}{l}\text { Exposure } \\
\text { Parameter }\end{array}$ & Exposure Parameter Definition & Units & $\begin{array}{l}\text { Typical } \\
\text { Person }{ }^{1}\end{array}$ & $\begin{array}{l}\text { Reference } \\
\text { Person }^{2}\end{array}$ & Reference \\
\hline & & & & & 4 \\
\hline$\rho_{\text {ss }}$ & soil bulk density $(1.50 \mathrm{~kg} / \mathrm{L})$ & $\mathrm{kg} / \mathrm{m}^{3}$ & 1500 & 1500 & $\begin{array}{l}\text { FBP } 2013 \text { App. B Table } \\
4\end{array}$ \\
\hline \multicolumn{6}{|c|}{ Ingestion of Soil Exposure Parameters } \\
\hline$U_{s(g)}$ & $\begin{array}{l}\text { age-adjusted human consumption rate of soil (120 } \\
\text { mg/day at } 350 \text { days/yr) }\end{array}$ & $\mathrm{kg} / \mathrm{yr}$ & 0.042 & 0.042 & $\begin{array}{l}\text { FBP } 2013 \text { App. B Table } \\
4\end{array}$ \\
\hline$f_{y r(g)}$ & fraction of year spent working in vegetable garden & unitless & 0.01 & 0.01 & Jannik et al., 2010 \\
\hline \multicolumn{6}{|c|}{ Ingestion of beef watered with contaminated water and fed on fodder irrigated with contaminated water Exposure Parameters } \\
\hline$U_{b}$ & human consumption rate of beef & $\mathrm{kg} / \mathrm{yr}$ & 32 & 81 & Stone \& Jannik, 2013 \\
\hline$f_{b}$ & $\begin{array}{l}\text { fraction of beef from cows raised on affected } \\
\text { pasture }\end{array}$ & unitless & 0.319 & 1 & Jannik et al., 2010 \\
\hline$f_{f b}$ & $\begin{array}{l}\text { fraction of fodder taken from irrigated pasture } \\
\text { (beef cow) }\end{array}$ & unitless & 0.75 & 0.75 & Jannik et al., 2010 \\
\hline$Q_{f, b}$ & beef cattle consumption rate of fodder & $\mathrm{kg} / \mathrm{d}$ & 36 & 36 & Jannik et al., 2010 \\
\hline$f_{c w b}$ & $\begin{array}{l}\text { fraction of water for beef cows from contaminated } \\
\text { water }\end{array}$ & unitless & 1 & 1 & Jannik et al., 2010 \\
\hline$Q_{w b}$ & beef cow consumption rate of water & $\mathrm{L} / \mathrm{d}$ & 28 & 28 & Jannik et al., 2010 \\
\hline$t_{b}$ & harvest to consumption time for beef & $\mathrm{d}$ & 6 & 6 & Jannik et al., 2010 \\
\hline \multicolumn{6}{|c|}{ Ingestion of Milk Exposure Parameters } \\
\hline$U_{m}$ & human consumption rate of milk & $\mathrm{L} / \mathrm{yr}$ & 69 & 260 & Stone \& Jannik, 2013 \\
\hline$f_{m}$ & $\begin{array}{l}\text { fraction of milk from cows raised on affected } \\
\text { pasture }\end{array}$ & unitless & 0.254 & 1 & Jannik et al., 2010 \\
\hline$f_{f m}$ & $\begin{array}{l}\text { fraction of fodder taken from irrigated pasture } \\
\text { (milk cow) }\end{array}$ & unitless & 0.56 & 0.56 & Jannik et al., 2010 \\
\hline$Q_{f m}$ & milk cow consumption rate of animal fodder & $\mathrm{kg} / \mathrm{d}$ & 52 & 52 & Jannik et al., 2010 \\
\hline$f_{\text {cwm }}$ & $\begin{array}{l}\text { fraction of water for milk cows from contaminated } \\
\text { water }\end{array}$ & unitless & 1 & 1 & Jannik et al., 2010 \\
\hline$Q_{w m}$ & milk cow consumption rate of water & $\mathrm{L} / \mathrm{d}$ & 50 & 50 & Jannik et al., 2010 \\
\hline$t_{m}$ & harvest to consumption time for milk & $\mathrm{d}$ & 3 & 3 & Jannik et al., 2010 \\
\hline \multicolumn{6}{|c|}{ Ingestion of Poultry Exposure Parameters } \\
\hline$f_{f p}$ & $\begin{array}{l}\text { fraction of fodder taken from irrigated pasture } \\
\text { (poultry) }\end{array}$ & unitless & 1 & 1 & $\begin{array}{l}\text { SRR } 2012 \text { \& Lee and } \\
\text { Coffield 2008a }\end{array}$ \\
\hline$Q_{f p}$ & poultry consumption rate of fodder & $\mathrm{kg} / \mathrm{d}$ & 0.1 & 0.1 & SRR 2012 \& Simpkins \\
\hline
\end{tabular}




\begin{tabular}{|c|c|c|c|c|c|}
\hline $\begin{array}{l}\text { Exposure } \\
\text { Parameter }\end{array}$ & Exposure Parameter Definition & Units & $\begin{array}{l}\text { Typical } \\
\text { Person }\end{array}$ & $\begin{array}{c}\text { Reference } \\
\text { Person }^{2}\end{array}$ & Reference \\
\hline & & & & & et al. 2008 \\
\hline$F_{c w p}$ & $\begin{array}{l}\text { fraction of water for poultry from contaminated } \\
\text { water }\end{array}$ & unitless & 1 & 1 & $\begin{array}{l}\text { SRR } 2012 \text { \& Lee and } \\
\text { Coffield 2008a }\end{array}$ \\
\hline$Q_{w p}$ & poultry consumption rate of water & $\mathrm{L} / \mathrm{d}$ & 0.3 & 0.3 & $\begin{array}{l}\text { SRR } 2012 \text { \& Simpkins } \\
\text { et al. } 2008\end{array}$ \\
\hline$U_{p}$ & human consumption rate of poultry & $\mathrm{kg} / \mathrm{yr}$ & 25 & 25 & $\begin{array}{l}\text { SRR } 2012 \text { \& Simpkins } \\
\text { et al. } 2008\end{array}$ \\
\hline$f_{p}$ & fraction of poultry raised on affected pasture & unitless & 0.306 & 0.306 & $\begin{array}{l}\text { SRR } 2012 \text { \& Simpkins } \\
\text { et al. } 2008\end{array}$ \\
\hline$t_{p}$ & harvest to consumption time for poultry & $\mathrm{d}$ & 1 & 1 & $\begin{array}{l}\text { Minimal duration } \\
\text { assumed }\end{array}$ \\
\hline \multicolumn{6}{|c|}{ Ingestion of Eggs Exposure Parameters } \\
\hline$U_{e}$ & human consumption rate of eggs & $\mathrm{kg} / \mathrm{yr}$ & 19 & 19 & $\begin{array}{l}\text { SRR } 2012 \text { \& Simpkins } \\
\text { et al. } 2008\end{array}$ \\
\hline$f_{e}$ & $\begin{array}{l}\text { fraction of eggs obtained from hens raised on } \\
\text { affected pasture }\end{array}$ & unitless & 1 & 1 & $\begin{array}{l}\text { SRR } 2012 \text { \& Lee and } \\
\text { Coffield 2008a }\end{array}$ \\
\hline$t_{e}$ & harvest to consumption time for eggs & $\mathrm{d}$ & 1 & 1 & $\begin{array}{l}\text { Minimal duration } \\
\text { assumed }\end{array}$ \\
\hline \multicolumn{6}{|c|}{ Inhalation of Shower Water Exposure Parameters } \\
\hline$U_{a}$ & $\begin{array}{l}\text { age-adjusted inhalation rate }\left(18 \mathrm{~m}^{3} / \text { day at } 350\right. \\
\text { days/yr) }\end{array}$ & $\mathrm{m}^{3} / \mathrm{yr}$ & 6300 & 6300 & $\begin{array}{l}\text { FBP } 2013 \text { App. B Table } \\
4\end{array}$ \\
\hline$t_{s}$ & $\begin{array}{l}\text { resident adult shower exposure time }(0.25 \mathrm{hr} / \text { day } \\
\text { at } 350 \text { days/yr) }\end{array}$ & Unitless & 0.01 & 0.01 & $\begin{array}{l}\text { FBP } 2013 \text { App. D Table } \\
\text { D.2 }\end{array}$ \\
\hline$C_{w s}$ & water contained in air at shower conditions & $\mathrm{g} / \mathrm{m}^{3}$ & 41 & 41 & SRR 2012 \& FFS 2003 \\
\hline$A R F$ & airborne release fraction & Unitless & $1.0 \mathrm{E}-04$ & $1.0 \mathrm{E}-04$ & SRR 2012 \& DOE 1994 \\
\hline$\rho_{w}$ & water density & $\mathrm{kg} / \mathrm{m}^{3}$ & 1000 & 1000 & Lee and Coffield 2008a \\
\hline \multicolumn{6}{|c|}{ Inhalation of Garden Water Exposure Parameters } \\
\hline$C_{w a}$ & water contained in air at ambient conditions & $\mathrm{g} / \mathrm{m}^{3}$ & 10 & 10 & FFS 2003 \\
\hline \multicolumn{6}{|c|}{ Inhalation of Garden Dust Exposure Parameters } \\
\hline$L_{a(g)}$ & $\begin{array}{l}\text { atmospheric mass loading of suspended soil } \\
\text { particulates in the garden }\end{array}$ & $\mathrm{kg} / \mathrm{m}^{3}$ & $1.00 \mathrm{E}-07$ & $1.00 \mathrm{E}-07$ & Lee and Coffield, 2008a \\
\hline \multicolumn{6}{|c|}{ Direct Exposure to Garden Soil Exposure Parameters } \\
\hline & no additional exposure parameters & & & & \\
\hline
\end{tabular}


Notes to Table 5-12:

- Exposure parameters are only shown the first time they are used by an exposure scenario; exposure parameters used again in subsequent exposure scenarios are not duplicated within this table.

- Exposure parameters with Portsmouth site-specific values are highlighted in blue.

1 The "Typical Person" exposure parameters are used for the base case. The "Typical Person" is a hypothetical aggregation of human (male and female) physical and physiological characteristics over various ages that is typical of the entire population group and it is established at the 50th percentile (median) of national usage data.

2 The "Reference Person" exposure parameters are used for sensitivity case \#5. The "Reference Person" is a hypothetical aggregation of human (male and female) physical and physiological characteristics over various ages that represents a highly exposed individual established at the 95th percentile of national usage data. 
Table 5-13. Radionuclide Soil/Water Partition Coefficients $\left(K_{d, i}\right)$

\begin{tabular}{|c|c|c|c|c|c|}
\hline Radionuclide & $\begin{array}{c}\text { Soil /Water } \\
\text { Partition } \\
\text { Coefficients } \\
\text { (mL/g) } \\
\end{array}$ & Reference & Radionuclide & $\begin{array}{c}\text { Soil /Water } \\
\text { Partition } \\
\text { Coefficients } \\
\text { (mL/g) } \\
\end{array}$ & Reference \\
\hline Ac- $225^{1}$ & $2,705.6$ & $\begin{array}{l}\text { FBP 2014a \& Kaplan } \\
2010\end{array}$ & Po- $218^{2}$ & 2000 & Kaplan 2010 \\
\hline Ac- $227^{1}$ & $2,705.6$ & $\begin{array}{l}\text { FBP 2014a \& Kaplan } \\
2010\end{array}$ & $\mathrm{Pu}-238$ & $1,432.4$ & FBP 2014a \\
\hline Ac- $228^{1}$ & 2,705.6 & $\begin{array}{l}\text { FBP 2014a \& Kaplan } \\
2010\end{array}$ & $\mathrm{Pu}-239$ & $1,432.4$ & FBP 2014a \\
\hline Am-241 & $2,705.6$ & FBP 2014a & $\mathrm{Ra}-223^{2}$ & 5 & Kaplan 2010 \\
\hline At-217 ${ }^{2}$ & 0.3 & Kaplan 2010 & $\mathrm{Ra}-224^{2}$ & 5 & Kaplan 2010 \\
\hline At-218 ${ }^{2}$ & 0.3 & Kaplan 2010 & $\mathrm{Ra}-225^{2}$ & 5 & Kaplan 2010 \\
\hline $\mathrm{Bi}-210^{1}$ & $2,705.6$ & $\begin{array}{l}\text { FBP 2014a \& Kaplan } \\
2010\end{array}$ & Ra- $226^{2}$ & 5 & Kaplan 2010 \\
\hline $\mathrm{Bi}-211^{1}$ & 2,705.6 & $\begin{array}{l}\text { FBP 2014a \& Kaplan } \\
2010\end{array}$ & Ra- $228^{2}$ & 5 & Kaplan 2010 \\
\hline $\mathrm{Bi}-212^{1}$ & $2,705.6$ & $\begin{array}{l}\text { FBP 2014a \& Kaplan } \\
2010\end{array}$ & $\mathrm{Rn}-218^{2}$ & 0 & Kaplan 2010 \\
\hline $\mathrm{Bi}-213^{1}$ & $2,705.6$ & $\begin{array}{l}\text { FBP 2014a \& Kaplan } \\
2010\end{array}$ & $\mathrm{Rn}-219^{2}$ & 0 & Kaplan 2010 \\
\hline $\mathrm{Bi}-214^{1}$ & 2,705.6 & $\begin{array}{l}\text { FBP 2014a \& Kaplan } \\
2010\end{array}$ & $\mathrm{Rn}-220^{2}$ & 0 & Kaplan 2010 \\
\hline Fr-221 2 & 10 & Kaplan 2010 & $\mathrm{Rn}-222^{2}$ & 0 & Kaplan 2010 \\
\hline Fr-223 2 & 10 & Kaplan 2010 & Tc-99 & 4.29 & FBP 2014a \\
\hline Np-237 & 795.8 & FBP 2014a & Th-227 & $5,411.3$ & FBP 2014a \\
\hline Pa- $231^{3}$ & 795.8 & $\begin{array}{l}\text { FBP 2014a \& Kaplan } \\
2010\end{array}$ & Th-228 & $5,411.3$ & FBP 2014a \\
\hline $\mathrm{Pa}-233^{3}$ & 795.8 & $\begin{array}{l}\text { FBP 2014a \& Kaplan } \\
2010\end{array}$ & Th-229 & $5,411.3$ & FBP 2014a \\
\hline $\mathrm{Pa}-234^{3}$ & 795.8 & $\begin{array}{l}\text { FBP 2014a \& Kaplan } \\
2010\end{array}$ & Th-230 & $5,411.3$ & FBP 2014a \\
\hline $\mathrm{Pa}-234 \mathrm{~m}^{3}$ & 795.8 & $\begin{array}{l}\text { FBP 2014a \& Kaplan } \\
2010\end{array}$ & Th-231 & $5,411.3$ & FBP 2014a \\
\hline $\mathrm{Pb}-209^{2}$ & 2000 & Kaplan 2010 & Th-232 & $5,411.3$ & FBP 2014a \\
\hline $\mathrm{Pb}-210^{2}$ & 2000 & Kaplan 2010 & Th-234 & $5,411.3$ & FBP 2014a \\
\hline $\mathrm{Pb}-211^{2}$ & 2000 & Kaplan 2010 & $\mathrm{Tl}^{2} 207^{2}$ & 10 & Kaplan 2010 \\
\hline $\mathrm{Pb}-212^{2}$ & 2000 & Kaplan 2010 & Tl-208 ${ }^{2}$ & 10 & Kaplan 2010 \\
\hline $\mathrm{Pb}-214^{2}$ & 2000 & Kaplan 2010 & Tl-209 ${ }^{2}$ & 10 & Kaplan 2010 \\
\hline Po- $210^{2}$ & 2000 & Kaplan 2010 & $\mathrm{Tl}-210^{2}$ & 10 & Kaplan 2010 \\
\hline Po-211 2 & 2000 & Kaplan 2010 & $\mathrm{U}-233$ & 22.60 & FBP 2014a \\
\hline Po-212 ${ }^{2}$ & 2000 & Kaplan 2010 & U-234 & 22.60 & FBP 2014a \\
\hline Po-213 ${ }^{2}$ & 2000 & Kaplan 2010 & $\mathrm{U}-235$ & 22.60 & FBP 2014a \\
\hline Po- $214^{2}$ & 2000 & Kaplan 2010 & U-235m & 22.60 & FBP 2014a \\
\hline
\end{tabular}




\begin{tabular}{|l|c|l|l|c|c|}
\hline Radionuclide & $\begin{array}{c}\text { Soil /Water } \\
\text { Partition } \\
\text { Coefficients } \\
\text { (mL/g) }\end{array}$ & Reference & Radionuclide & $\begin{array}{c}\text { Soil /Water } \\
\text { Partition } \\
\text { Coefficients } \\
\text { (mL/g) }\end{array}$ & Reference \\
\hline Po-215 ${ }^{2}$ & 2000 & Kaplan 2010 & U-236 & 22.60 & FBP 2014a \\
\hline Po-216 ${ }^{2}$ & 2000 & Kaplan 2010 & U-238 & 22.60 & FBP 2014a \\
\hline
\end{tabular}

Notes to Table 5-13:

- $\quad$ Portsmouth site-specific $\mathrm{K}_{\mathrm{d}} \mathrm{s}$ were utilized as provided in FBP 2014a Appendix I Table I.12 as available and are highlighted in blue.

1 Based upon Kaplan 2010 the $\mathrm{K}_{\mathrm{d}} \mathrm{S}$ of Actinium (Ac) and Bismuth (Bi) for a given geologic material are the same as that of Americium (Am), therefore the Portsmouth site-specific $K_{d}$ for Am was assigned to both Ac and Bi.

2 Elements for which Portsmouth site-specific $K_{d} s$ are not available from FBP 2014a Appendix I Table I.12, the $K_{d} S$ for sandy sediment from Kaplan 2010 were utilized. A comparison of the Kaplan 2010 sandy sediment $K_{d} s$ for elements that also had Portsmouth site-specific $K_{d} s$ within FBP 2014a revealed that 5 of the 6 Kaplan 2010 sandy sediment $K_{d} s$ were less than the Portsmouth site-specific $\mathrm{K}_{\mathrm{d}} \mathrm{s}$. Therefore the use of the Kaplan 2010 sandy sediment $\mathrm{K}_{\mathrm{d}} \mathrm{s}$ is considered conservative versus the vegetative ingestion exposure pathway/scenario.

3 Based upon Kaplan 2010 the $\mathrm{K}_{\mathrm{d}}$ of Protactinium (Pa) for a given geologic material is the same as that of Neptunium (Np), therefore the Portsmouth site-specific $\mathrm{K}_{\mathrm{d}}$ for Np was assigned to Pa.

\subsection{Portsmouth OSWDF All-Pathways Dose Model Runs and Results}

In this section, we discuss and compare results from the dose calculations made to evaluate a base case OSWDF scenario and five sensitivity cases varying different aspects of the base case scenario. A list of the six dose calculations performed for this study indicating the parameter values used is shown in Table 6-1. The Base Case scenario has the following structure:

1) Use of the most reasonable estimate of the OSWDF disposal inventory and configuration,

2) Assumption that POA-3 is the uncontaminated Berea aquifer,

3) Use of STOMP transport results calculated with nominal uranium $K_{d}$ values,

4) Use of transfer factors that were used in the OSWDF intruder dose analysis and

5) Calculation of the dose to a typical person representing the $50^{\text {th }}$ percentile of the population.

Sensitivity Case 1 replaces the reasonable estimate of OSWDF inventory and configuration with a higher disposal inventory for each radionuclide and a revised OSWDF configuration that would lead to earlier arrival of contamination at the points of assessment (see Section 4.0). Sensitivity Case 2 assumes that the Berea aquifer mixes with contaminated water from the 680 Sandstone layer in the ratio of 95:5 (see Section 4.0). Sensitivity Case 3 uses STOMP transport results calculated using a reduced uranium $K_{d}$ in the waste zone (see Section 4.0). Sensitivity Case 4 uses the most recently published IAEA bio-transfer factors for soil-to-vegetable, feed-to-beef, and feed-to-milk, where available. The primary impact of this change is that the soil-plant bio-transfer factor for Tc is significantly increased (17.9 vs 0.065) based on the latest IAEA published factors. Sensitivity Case 5 uses dose parameters appropriate for a reference person representing the $95^{\text {th }}$ percentile of the population.

The Base Case and Sensitivity Cases all assume that the dose is to an individual who uses well water drawn from the Berea aquifer below the OSWDF site and who consumes produce and animal products raised at the site using irrigation water and to water livestock from a surface pond receiving seepage from the 680 Sandstone layer. Results from the dose calculations are summarized in Table 6-2. In general, for 
the first 1,000 years following site closure, insignificant doses (from Tc-99) to an individual are predicted to occur for all cases. Doses remain below 0.1 (mrem/yr) throughout the first 10,000 years except for Sensitivity Case 2 where the Berea aquifer becomes contaminated and doses reach just over $10 \%$ of the 25 (mrem/yr) dose limit.

The discussion in this Section focuses on the most significant differences found in results from the various case studies in contrast to the Base Case. Plots of dose by ingestion pathways, dose by parent radionuclide, and dose by pathway (ingestion, inhalation and external exposure) for each of these cases are provided as part of the following discussion. For Sensitivity Case 2, where drinking and shower water were obtained from the Berea aquifer contaminated with water from the 680 sandstone layer, dose by POA is also plotted. For the other cases, no dose to the individual was predicted to occur from consumption of Berea aquifer water. 
Table 6-1. Case Definitions

\begin{tabular}{|c|c|c|c|c|c|c|c|c|c|c|}
\hline \multirow{2}{*}{ Case } & \multicolumn{2}{|c|}{ Inventory Scenario } & \multicolumn{2}{|c|}{ POA-3 Scenario } & \multicolumn{2}{|c|}{$\begin{array}{l}\text { U Source } \mathbf{K}_{\mathbf{d}} \\
\text { Scenario }\end{array}$} & \multicolumn{2}{|c|}{$\begin{array}{c}\text { Transfer Factor } \\
\text { Scenario }\end{array}$} & \multicolumn{2}{|c|}{$\begin{array}{c}\text { Exposure } \\
\text { Parameters } \\
\text { Scenario }\end{array}$} \\
\hline & $\begin{array}{c}\text { Reasonable } \\
\text { Case }\end{array}$ & $\begin{array}{c}\text { Conservative } \\
\text { Case }\end{array}$ & $\begin{array}{l}\text { Cased } \\
\text { Well }^{1}\end{array}$ & $\begin{array}{c}\text { Uncased } \\
\text { Well }^{2}\end{array}$ & $\begin{array}{c}\text { Nominal } \\
\mathbf{K}_{\mathbf{d}}{ }^{3}\end{array}$ & $\begin{array}{l}\text { Low } \\
\text { K }_{d}{ }^{4}\end{array}$ & $\begin{array}{l}\text { Base } \\
\text { Case }\end{array}$ & $\begin{array}{c}\text { Sensitivity } \\
\text { Case }\end{array}$ & $\begin{array}{l}\text { Typical } \\
\text { Person }\end{array}$ & $\begin{array}{c}\text { Reference } \\
\text { Person }\end{array}$ \\
\hline Base Case & $\mathrm{X}$ & & $\mathrm{X}$ & & $\mathrm{X}$ & & $\mathrm{X}$ & & $\mathrm{X}$ & \\
\hline Sensitivity \#1 & & $\mathrm{X}$ & $\mathrm{X}$ & & $\mathrm{X}$ & & $\mathrm{X}$ & & $\mathrm{X}$ & \\
\hline Sensitivity \#2 & $\mathrm{X}$ & & & $\mathrm{X}$ & $\mathrm{X}$ & & $\mathrm{X}$ & & $\mathrm{X}$ & \\
\hline Sensitivity \#3 & $\mathrm{X}$ & & $\mathrm{X}$ & & & $\mathrm{X}$ & $\mathrm{X}$ & & $\mathrm{X}$ & \\
\hline Sensitivity \#4 & $\mathrm{X}$ & & $\mathrm{X}$ & & $\mathrm{X}$ & & & $\mathrm{X}$ & $\mathrm{X}$ & \\
\hline Sensitivity \#5 & $\mathrm{X}$ & & $\mathrm{X}$ & & $\mathrm{X}$ & & $\mathrm{X}$ & & & $\mathrm{X}$ \\
\hline
\end{tabular}

Notes to Table:

$1 \quad 100 \%$ Berea groundwater.

$295 \%$ Berea groundwater and 5\% 680 SSL.

3 Nominal uranium $\mathrm{K}_{\mathrm{d}}=365 \mathrm{~mL} / \mathrm{g}$.

$4 \quad$ Low uranium $\mathrm{K}_{\mathrm{d}}=14.6 \mathrm{~mL} / \mathrm{g}$.

- Input Tables 5-8, 5-9, and 5-13 are used for all cases (i.e. Base Case and Sensitivity Case \#1 through \#5).

- $\quad$ Base Case input tables: Table 4-1 reasonable case inventory; Table 4-3 POA-1 SW Zone Base Case; Table 4-4 POA-3 GW Base Case; Table 5-5 Base Case Irrigation and Watering Pond; Table 5-10 Base Case Transfer Factors; and Table 5-12 typical person exposure parameters.

- Sensitivity Case \#1 input tables: Table 4-1 conservative case inventory; Table 4-5 POA-1 SW Zone Sensitivity Case \#1; Table 4-6 POA-3 GW Sensitivity Case \#1; Table 5-6 Sensitivity Case \#1 Irrigation and Watering Pond; Table 5-10 Base Case Transfer Factors; and Table 5-12 typical person exposure parameters.

- Sensitivity Case \#2 input tables: Table 4-1 reasonable case inventory; Table 4-3 POA-1 SW Zone Base Case; Table 4-7 POA-3 GW Sensitivity Case \#2; Table 5-5 Base Case Irrigation and Watering Pond; Table 5-10 Base Case Transfer Factors; and Table 5-12 typical person exposure parameters.

- $\quad$ Sensitivity Case \#3 input tables: Table 4-1 reasonable case inventory; Table 4-8 POA-1 SW Zone Sensitivity Case \#3; Table 4-9 POA-3 GW Sensitivity Case \#3; Table 5-7 Sensitivity Case \#3 Irrigation and Watering Pond; Table 5-10 Base Case Transfer Factors; and Table 5-12 typical person exposure parameters.

- $\quad$ Sensitivity Case \#4 input tables: Table 4-1 reasonable case inventory; Table 4-3 POA-1 SW Zone Base Case; Table 4-4 POA-3 GW Base Case; Table 55 Base Case Irrigation and Watering Pond; Table 5-11 Sensitivity Case \#4 Transfer Factors; and Table 5-12 typical person exposure parameters.

- Sensitivity Case \#5 input tables: Table 4-1 reasonable case inventory; Table 4-3 POA-1 SW Zone Base Case; Table 4-4 POA-3 GW Base Case; Table 5-5 Base Case Irrigation and Watering Pond; Table 5-10 Base Case Transfer Factors; and Table 5-12 reference person exposure parameters. 
Table 6-2. Summary of Results from All-Pathways Dose Calculations

\begin{tabular}{|c|c|c|c|c|c|c|}
\hline \multirow[b]{2}{*}{ Case } & \multicolumn{2}{|c|}{$\begin{array}{l}\text { Maximum Dose during } \\
\text { 1,000 Year Period of } \\
\text { Assessment }\end{array}$} & \multicolumn{2}{|c|}{$\begin{array}{c}\text { Maximum Dose at Any } \\
\text { Time } \leq 10,000 \text { yrs }\end{array}$} & \multirow{2}{*}{$\begin{array}{c}\text { Pathway } \\
\text { Giving } \\
\text { Highest } \\
\text { Dose }\end{array}$} & \multirow{2}{*}{$\begin{array}{c}\text { Nuclide } \\
\text { Giving } \\
\text { Highest } \\
\text { Dose }\end{array}$} \\
\hline & (mrem/yr) & (year) & (mrem/yr) & (year) & & \\
\hline Base Case & $1.5 \mathrm{E}-14$ & 1,000 & 0.0020 & 4,000 & Vegetable & Tc-99 \\
\hline Sensitivity \#1 & $1.4 \mathrm{E}-10$ & 1,000 & 0.064 & 10,000 & Vegetable & Tc-99 \\
\hline Sensitivity \#2 & 5.9E-11 & 1,000 & 2.55 & 8,000 & Water & Tc-99 \\
\hline Sensitivity \#3 & $1.5 \mathrm{E}-14$ & 1,000 & 0.038 & 10,000 & Vegetable & $\mathrm{U}-234$ \\
\hline Sensitivity \#4 & 3.9E-14 & 1,000 & 0.0052 & 4,000 & Vegetable & Tc-99 \\
\hline Sensitivity \#5 & $1.1 \mathrm{E}-13$ & 1,000 & 0.015 & 4,000 & Vegetable & Tc-99 \\
\hline
\end{tabular}

The Base Case scenario uses the reasonable estimate for OSWDF inventory, assumes that pond water contaminated with seepage from the 680 sandstone layer (POA-1) is the only dose source and calculates the dose to a typical individual $\left(50^{\text {th }}\right.$ percentile). This case also employs STOMP transport results obtained using a best estimate value for uranium $K_{d}$ and uses the dose coefficients employed in the OSWDF intruder analysis. Results of dose calculations for this case are presented in Figure 6-1. Figure 6-1(a) plots the total dose to an individual and the total doses from the three major dose pathways considered in the analysis (ingestion, inhalation and external exposure). The total dose for the Base Case is essentially equal to the ingestion dose with very small contributions from inhalation and external exposure. This result, that the ingestion dose is the largest contributor to total dose, is also true for all of the sensitivity case scenarios.

Figure 6-1(b) shows the contribution to total ingestion dose from the various ingestion pathways considered. The legend to the figure lists the pathways in order of highest maximum doses observed over the 10,000 year period of analysis. For the base case, where it is assumed that drinking water is not contaminated, the largest source of dose to an individual is the consumption of vegetables from a local garden that have been contaminated by irrigation with pond water containing seepage water from the 680 sandstone layer. Consumption of eggs is the next largest source of dose to an individual followed by consumption of meat and milk where the source of contamination is animal consumption of pond water and fodder that has been irrigated with pond water. From Figure 6-1(b), it is apparent that the inadvertent consumption of a small amount of contaminated soil while working in the garden contributes negligible dose.

Figure 6-1(c) shows the contribution to total dose from each parent radionuclide. The parent dose includes doses from daughter radionuclides which are assumed to transport along with the parent. For the base case, the peak dose of 0.002 (mrem/yr) occurs at 4,000 years and is almost entirely from Tc-99. However, by 10,000 years the dose from Tc-99 is declining while the dose from the uranium isotopes is increasing. U-234 contributes the highest dose of the four uranium isotopes considered.

Dose results for conservative inventory Sensitivity Case \#1 are shown in Figure 6-2. Figure 6-2(a) shows the dose contributions for Sensitivity Case \#1 by pathways. When compared to Figure 6-1(a), the total dose for Sensitivity Case \#1 is relatively constant from 3,000 to 10,000 years with the maximum total dose occurring at 10,000 years. This behavior is explained by comparing the dose by parent radionuclide for Sensitivity Case \#1 shown in Figure 6-2(c) with the result for the Base Case shown in Figure 6-1(c). These figures show that for the conservative waste inventory and distribution, the contribution to total dose from uranium isotopes increases relative to the dose from Tc-99 which leads to an increase in total 
dose at later times. Figure 6-2(b) shows that the order of contribution to total dose from the ingestion pathways considered is the same as that for the Base Case.

Sensitivity Case \#2 includes contamination of well water in the Berea aquifer (POA-3) by water from the 680 sandstone layer. Therefore, the additional dose pathways of water ingestion and inhalation of shower water, which do not apply in the other cases, contribute dose to an individual. Figure 6-3(a) shows the dose by pathways for Sensitivity Case \#2. Comparison with Figure 6-1(a) shows a significant increase in the ingestion dose from the direct consumption of contaminated water and a similar increase in inhalation dose although the dose from inhalation remains small. The ingestion dose, shown by ingestion pathway in Figure 6-3(b), is almost entirely from water ingestion and other contributions to ingestion dose remain the same as those for the Base Case shown in Figure 6-1(b). Figure 6-3(c) shows the dose from each parent radionuclide (including the contribution from decay products which are assumed to transport along with the parent) for Sensitivity Case \#2. Comparison with the results for the Base Case in Figure 6-1(c) shows that doses from each parent increased but the relative order remains the same. Figure 6-3(d) shows that the dose from POA-3 dominates the dose to an individual for this case. The peak dose over 10,000 years for Sensitivity Case \#2 is 2.55 (mrem/yr) which is approximately 1250 times greater than the dose from the Base Case. As outlined in Section 4.0, Sensitivity Case \#2 assumes that an uncased well to the Berea is placed at the location of the greatest concentration over time in the 680 SSL beyond the $100 \mathrm{~m}$ perimeter surrounding the OSWDF and allows leakage from the 680 SSL into the Berea (95\% Berea groundwater and 5\% 680 SSL leakage) from which it is pumped for domestic water usage. This is scenario is considered very unlikely for two reasons. First the leakage from the 680 SSL is assumed to come from the location of the greatest concentration over time beyond the $100 \mathrm{~m}$ perimeter. Second uncased wells are not permitted under the Ohio Administrative Code (Chapter 3701-28 Private Water Systems, 3701-28-10 Well construction, alteration, and maintenance). This portion of the Ohio Administrative Code requires that casing with watertight joints be used and that the annular space between the formation and casing be sealed with cement grout or bentonite grout, as appropriate. Such well construction would prevent leakage from the 680 SSL to the Berea aquifer.

Sensitivity Case \#3 used STOMP transport results obtained using a lower $\mathrm{K}_{\mathrm{d}}$ for uranium in the waste zone $(14.6 \mathrm{ml} / \mathrm{g}$ instead of the nominal $365 \mathrm{ml} / \mathrm{g})$. Doses from Tc-99 remain the same as for the Base Case while increased uranium concentration in the pond water leads to higher doses from the uranium isotopes. Results for this sensitivity case are shown in Figure 6-4. As shown in Figure 6-4(a) the ingestion pathway dominates the total dose. Figure 6-4(b) shows that while consumption of vegetables and eggs are still the primary ingestion dose pathways, consumption of poultry is relatively higher indicating a stronger dependence on uranium concentration than doses from milk and meat. Figure 6-4(c) shows doses from parent radionuclides for Sensitivity Case \#3. Beyond about 6,000 years, the dose from U-234 begins to exceed the dose from Tc-99 and the peak dose for Sensitivity Case \#3 occurs at 10,000 years while the uranium concentrations are still increasing.

Figure 6-5 shows dose results for Sensitivity Case \#4. This case used transfer factors that determine the transfer of radionuclides from the ingestion of contaminated feed and water by cattle to meat and milk and transfer of radionuclides from soil to plants updated to the latest values recommended by the IAEA (Table 5-11) where available. As noted above, the biggest impact from this change in dose coefficients from the nominal values used in the Portsmouth Intruder analysis (Table 5-10) is a significant increase in the transfer of Tc-99 from soil to plants. This is reflected in the results where an increased dose from Tc99 is observed in Figure 6-5(c) and the peak dose from Sensitivity Case \#4 increases to 0.0052 (mrem/yr) which is approximately 2.6 times greater than the peak dose in the Base Case. Figures 6-5(a) and 6-5(b) plot the dose by pathway and ingestion dose by ingestion pathway, respectively.

Sensitivity Case \#5 used nominal settings for transfer factors, uranium $\mathrm{K}_{\mathrm{d}}$, and the source of contaminated water. However, Sensitivity Case \#5 applies ingestion parameters appropriate for a $95^{\text {th }}$ percentile 
reference person to calculate the effective dose. These parameters include increased consumption of vegetables, meat, and milk which will increase the effective dose. Consequently, as shown in Figure 66(a), the contribution to total dose from ingestion pathways is higher for Sensitivity Case \#5 than for the Base Case. As shown in Figure 6-6(b), the dose from vegetable ingestion is the dominant pathway for this scenario. The relative contribution to total dose by parent radionuclides remains the same as in the Base Case as shown in Figure 6-6(c). Using dose parameters for the $95^{\text {th }}$ percentile instead of the $50^{\text {th }}$ percentile person increased the maximum dose over the 10,000 year period of analysis by approximately a factor of seven.

Table 6-3 provides an overall evaluation of the impact of each of the sensitivity cases relative to the Base Case. The sensitivity cases are listed in order of their increase over the Base Case considering the maximum doses at any time over a 10,000 year period of assessment. As seen Sensitivity Case \#2, which was requested by the OEPA for use in the Portsmouth WD RI/FS Report (FBP 2014a), by far has the greatest impact on dose. As outlined above, this scenario is considered very unlikely because it assumes leakage from the location of greatest concentration in the 680 SSL over time and does not conform to standard private water well construction practices. The increase over the Base Case and maximum doses at any time associated with all other sensitivity cases remain insignificant relative to the DOE allpathways $25 \mathrm{mrem} / \mathrm{yr}$ Performance Objective. The bottom-line is that all doses, including that of Sensitivity Case \#2, fall well below the DOE all-pathways 25 mrem/yr Performance Objective.

Table 6-3. Impact of Sensitivity Cases

\begin{tabular}{|l|l|r|r|}
\hline \multicolumn{1}{|c|}{ Case } & \multicolumn{1}{|c|}{ Description } & $\begin{array}{c}\text { Maximum } \\
\text { Dose at } \\
\text { Any Time } \\
\text { (mrem/yr) }\end{array}$ & $\begin{array}{c}\text { Increase } \\
\text { over Base } \\
\text { Case } \\
(-)\end{array}$ \\
\hline Base Case & & 0.002 & - \\
\hline Sensitivity \#2 & Uncased Well To Berea & 2.55 & 1275 \\
\hline Sensitivity \#1 & Conservative Inventory & 0.064 & 32 \\
\hline Sensitivity \#3 & Low uranium $K_{d}$ & 0.038 & 19 \\
\hline Sensitivity \#5 & Reference Person Exposure Parameters & 0.015 & 7.5 \\
\hline Sensitivity \#4 & Sensitivity Transfer Factor & 0.0052 & 2.6 \\
\hline
\end{tabular}


SRNL-STI-2014-00130

Revision 0

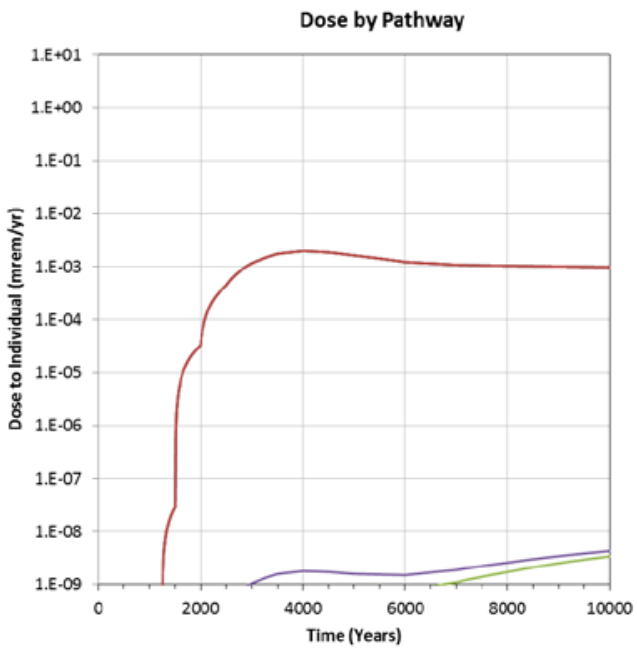

(a)

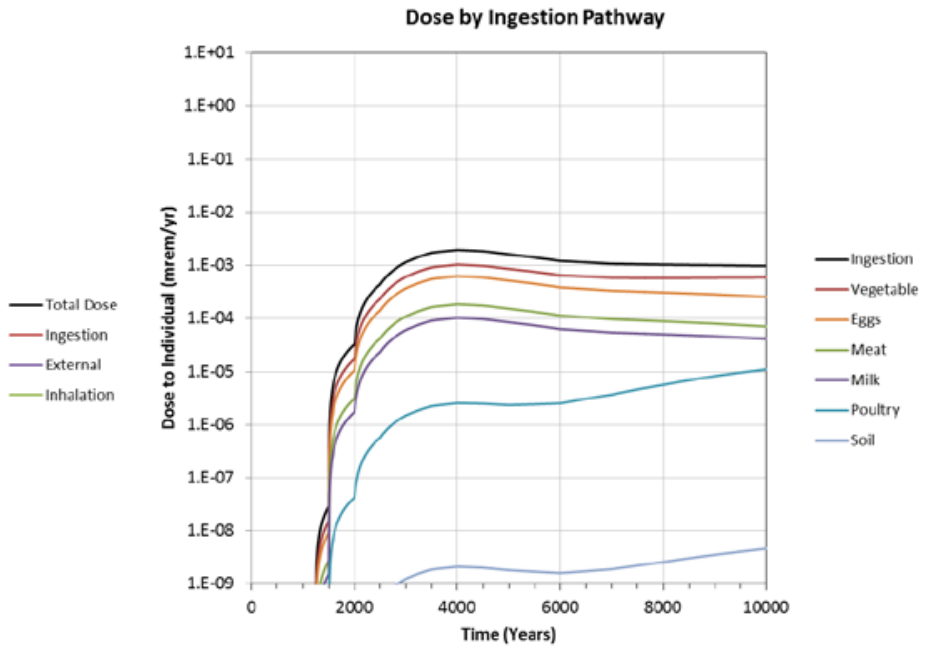

(b)

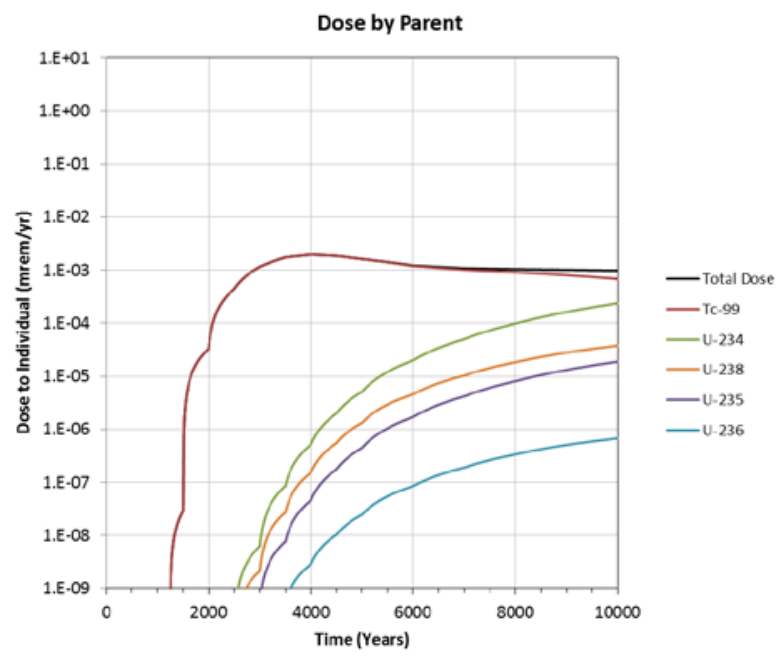

(c)

Figure 6-1. Dose Results for Base Case 
SRNL-STI-2014-00130

Revision 0

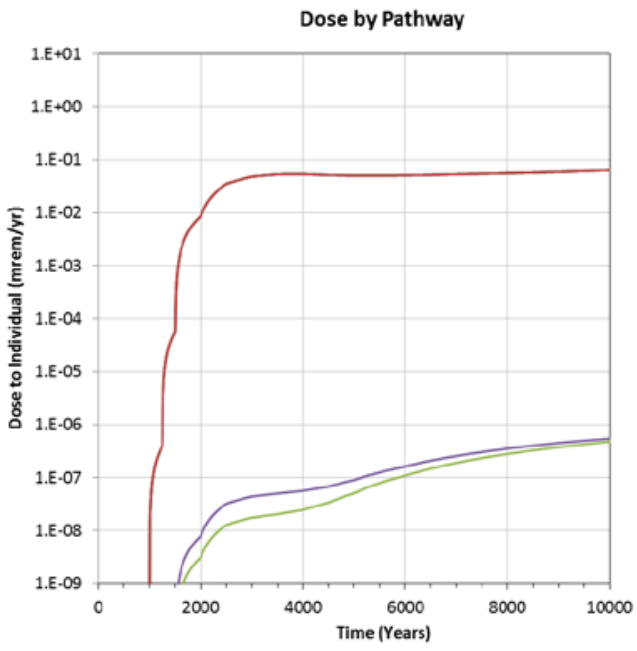

(a)

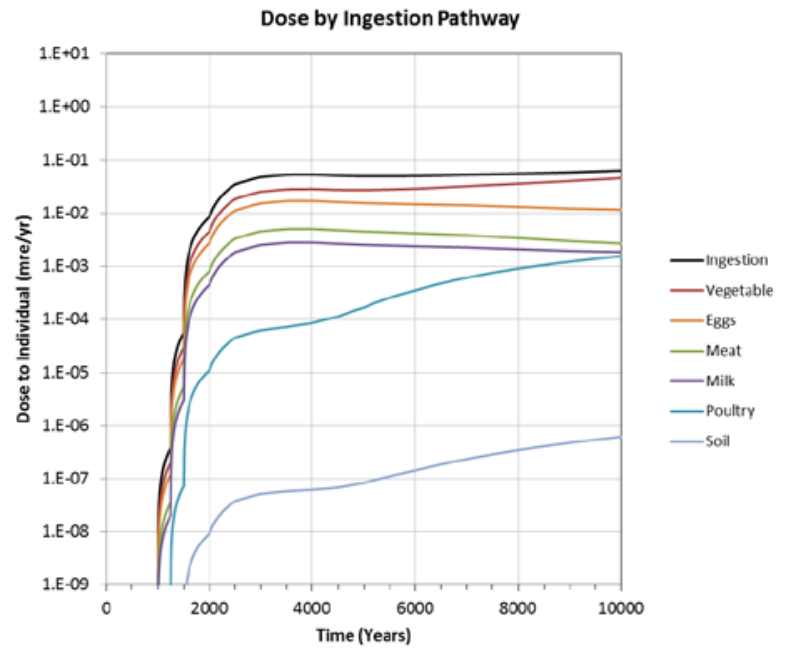

(b)

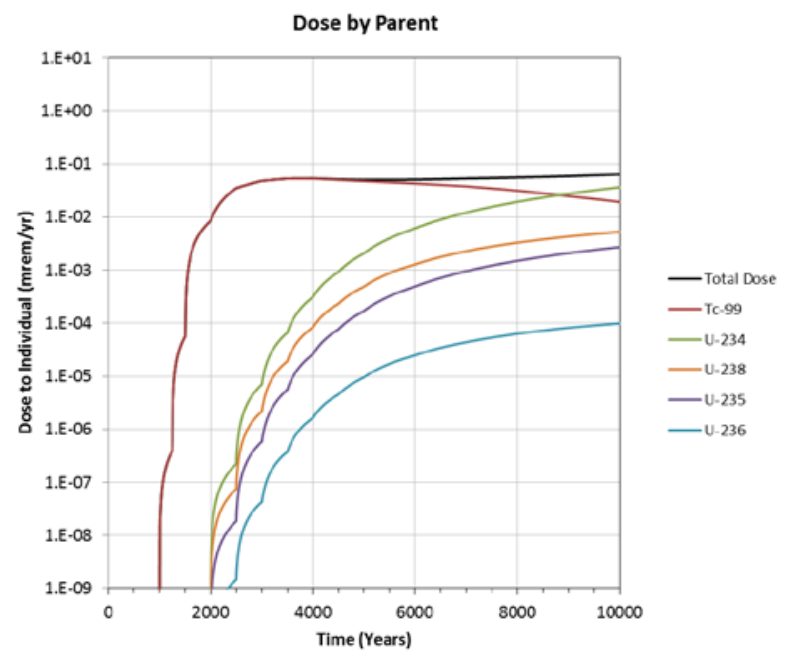

(c)

Figure 6-2. Dose Results for Sensitivity Case \#1 with a Conservative Inventory 
SRNL-STI-2014-00130

Revision 0

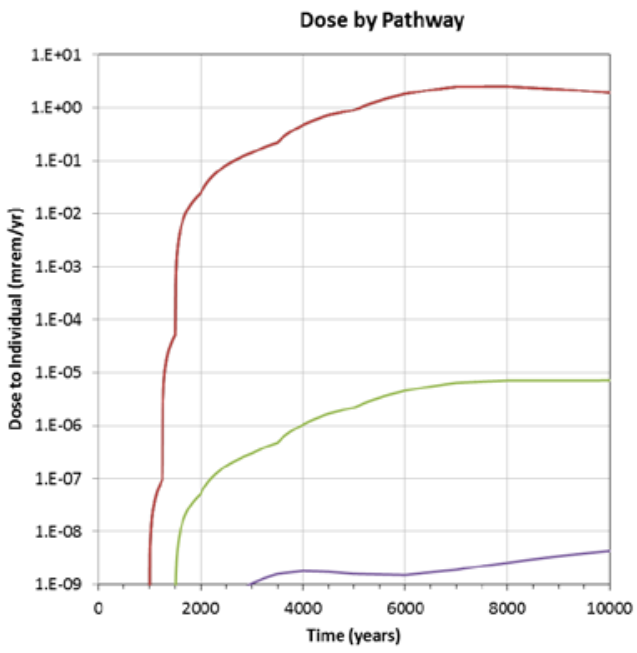

(a)

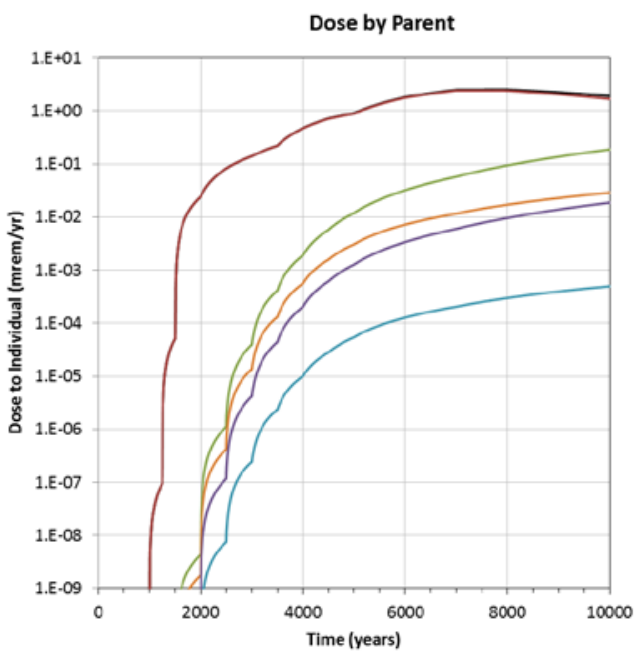

(c)

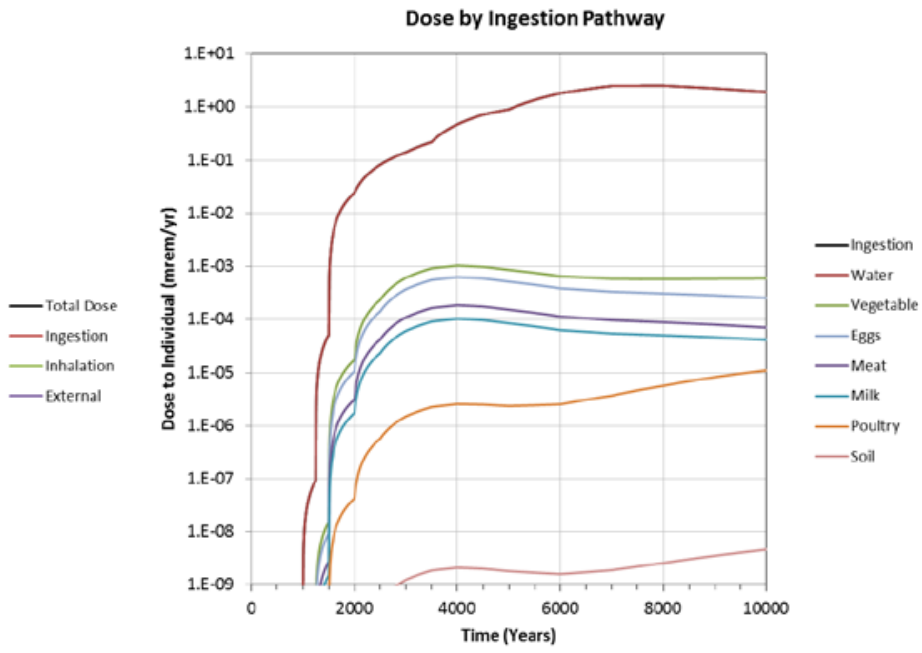

(b)

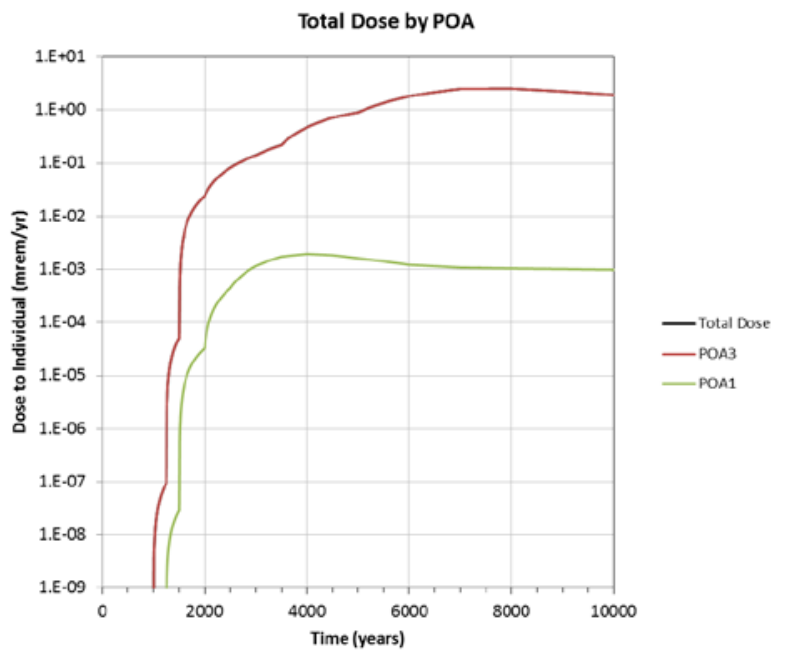

(d)

Figure 6-3. Dose Results for Sensitivity Case \#2 with Contaminated Well Water from the Berea Aquifer 
SRNL-STI-2014-00130

Revision 0

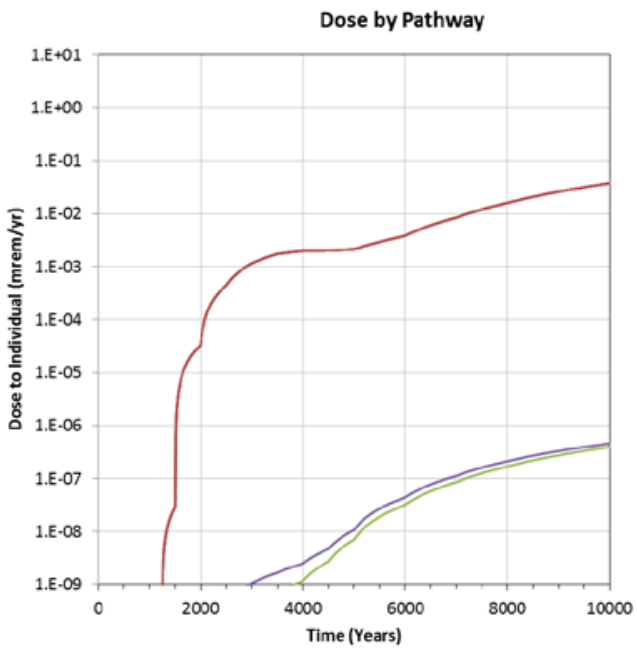

(a)

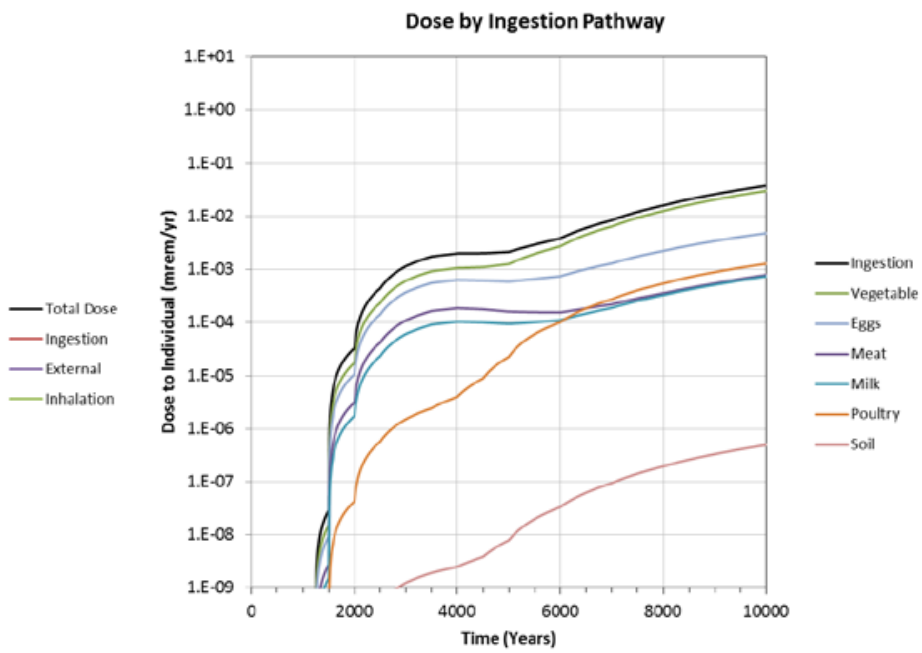

(b)

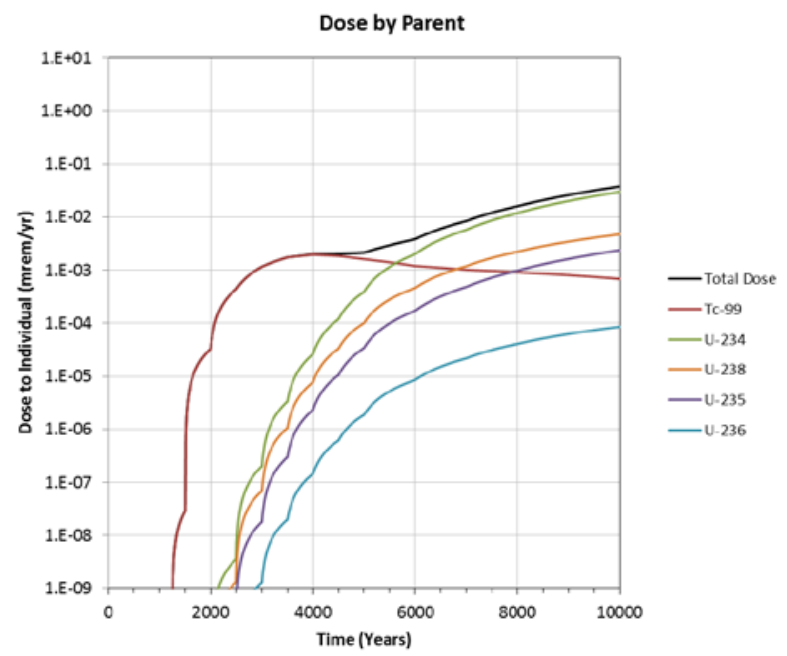

(c)

Figure 6-4. Dose Results for Sensitivity Case \#3 with Lower Uranium $K_{d}$ in the Waste Zone 
SRNL-STI-2014-00130

Revision 0

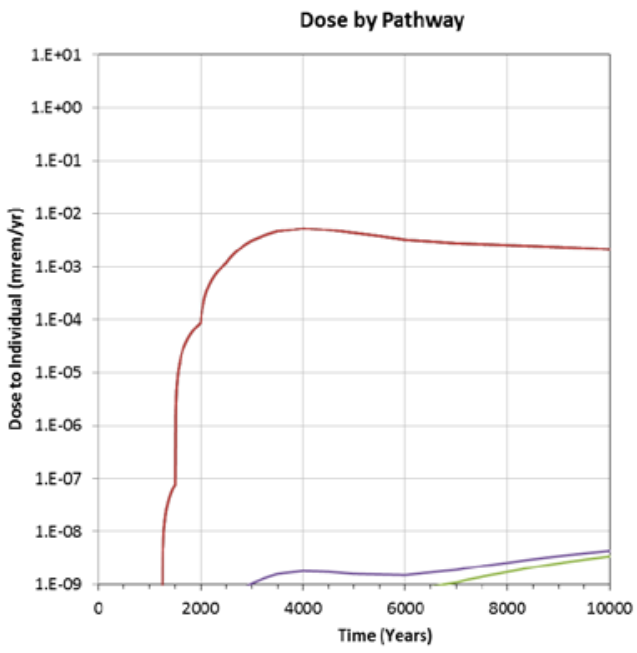

(a)

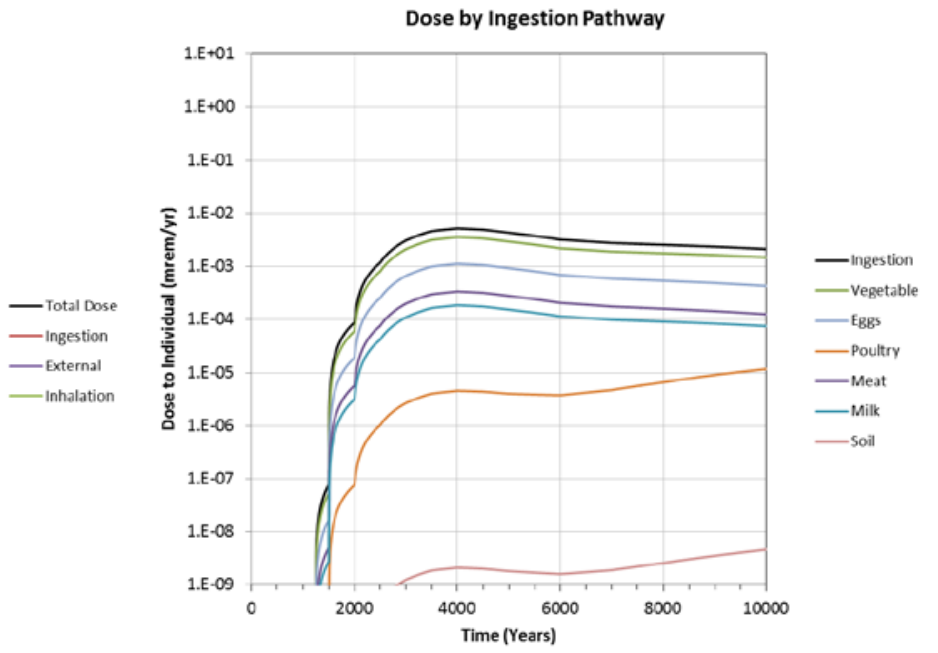

(b)

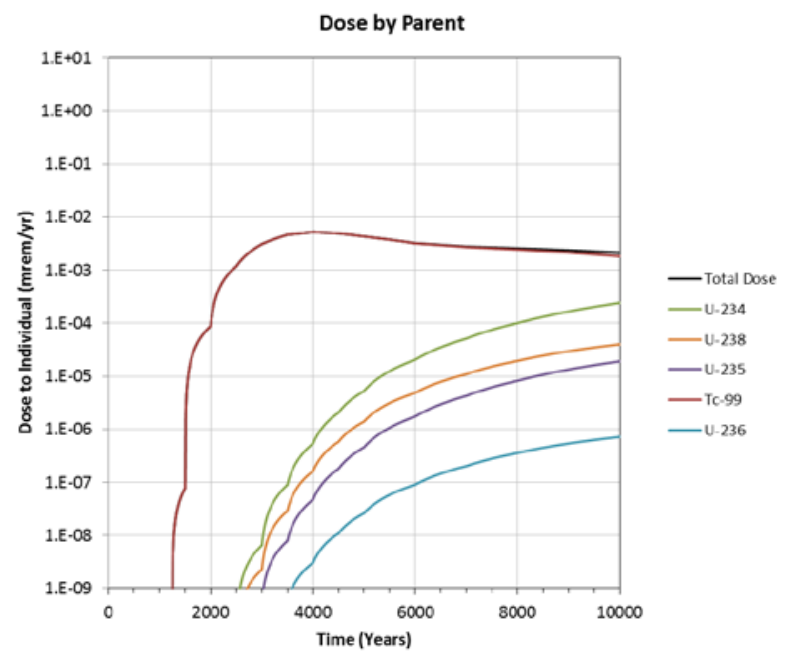

(c)

Figure 6-5. Dose Results for Sensitivity Case \#4 with IAEA Transfer Factors 
SRNL-STI-2014-00130

Revision 0

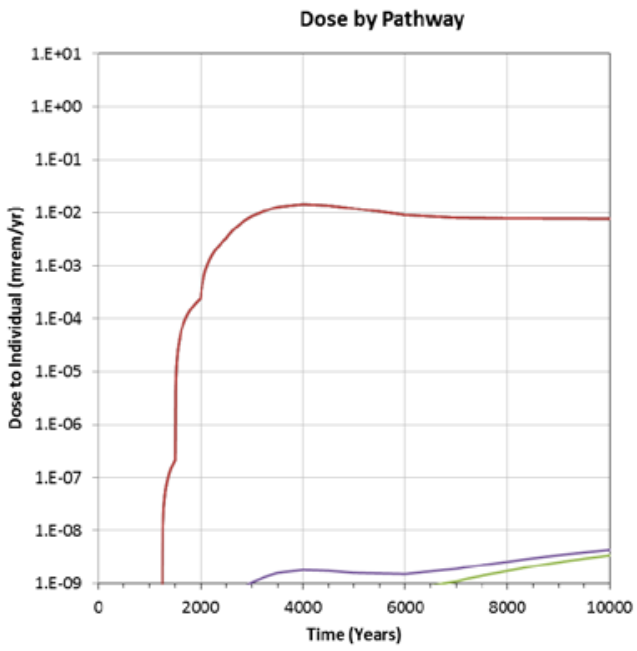

(a)

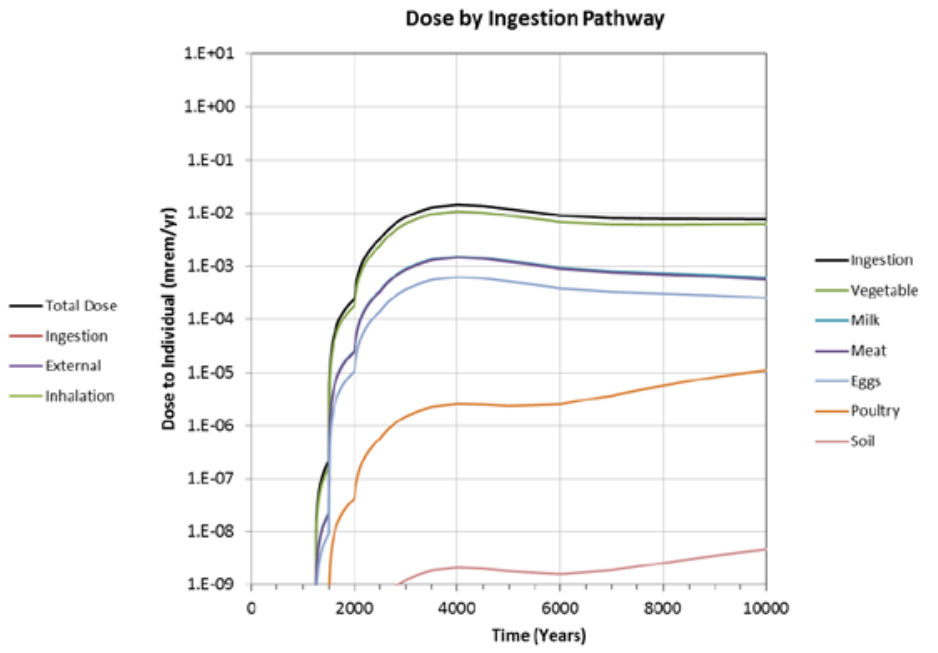

(b)

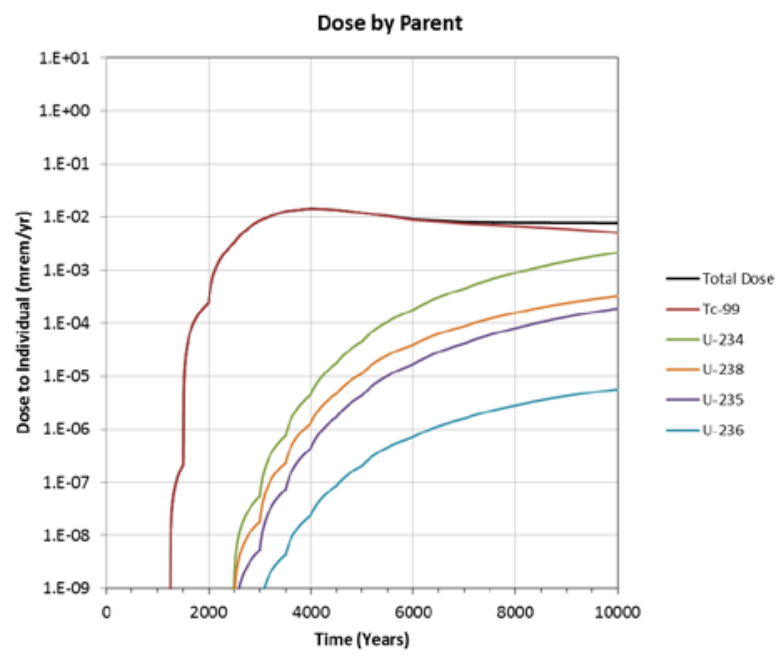

(c)

Figure 6-6. Dose Results for Sensitivity Case \#5 for a Reference Person 


\subsection{OSWDF Inventory Constraints Based on All-Pathways Dose Analysis}

Eleven parent radionuclides are included in the OSWDF all-pathways dose analysis. Results from STOMP transport modeling show no measurable concentrations of any radionuclide except for Tc-99 at any POA within 1,000 years from the time of burial for any of the scenarios evaluated. Sensitivity Case \#1 yielded the highest dose during this time period. The highest dose occurred at 1,000 years. For the Table 4-1 conservative case inventory of $385 \mathrm{Ci}$ of Tc-99 used in this sensitivity analysis, the maximum dose was $1.4 \mathrm{E}-10 \mathrm{mrem} / \mathrm{yr}$. From the ratio of the predicted dose to the dose limit of 25 (mrem/yr), the inventory constraint for Tc-99 is $6.3 \mathrm{E}+13$ Curies $(3.7 \mathrm{E}+12 \mathrm{~kg})$. Inventory limits for the other radionuclides are not bounded by the 1,000 year all-pathways dose analysis. Assuming an OSWDF volume of 5 million cubic yards $\left(3.82 \mathrm{E}+6 \mathrm{~m}^{3}\right)$ and a waste density of $3.2 \mathrm{~kg} / \mathrm{L}$ the entire disposal site can hold at most $1.22 \mathrm{E}+7 \mathrm{~kg}$ waste. Therefore it is not possible for the OSWDF to hold enough Tc-99 to reach the dose limit within 1,000 years.

If we take an extremely conservative approach and extend our estimate of inventory constraints over all scenarios and over 10,000 years from the time of burial, Table 6-2 shows that the maximum dose is 2.55 (mrem/yr) for Sensitivity Case \#2. Only Tc-99, U-234, U-235, U-236 and U-238 produced measurable concentrations at the POAs within 10,000 years. Therefore, the inventory of these radionuclides could be increased by a factor of 9.8 over the Table 4-1 reasonable case inventory before reaching the 25 (mrem/yr) dose limit. More realistically, considering only the Base Case scenario, which produced a maximum dose of 0.002 (mrem/yr) over 10,000 years, the inventory for Tc-99, U-234, U-235, U-236 and U-238 could be increased by a factor of 12,500 over the Table 4-1 reasonable case inventory before reaching the dose limit. Again, if the inventory of each parent was increased by this factor the mass of each one would exceed the capacity of the OSWDF by more than an order of magnitude.

\subsection{References}

Abitz, R. 2014. RE: Questions on All-Pathways Dose Analysis, email to Mark Phifer dated 01/23/2014.

Baes, C. F. III, Sharp, R. D., Sjoreen, A. L., and Shor, R. W., 1984, A Review and Analysis of Parameters for Assessing Transport of Environmentally Released Radionuclides Through Agriculture, ORNL-5786, Oak Ridge National Laboratory, Oak Ridge, Tennessee.

DOE 1999a, Radioactive Waste Management, Order 435.1, U.S. Department of Energy, Washington, DC.

DOE 1999b, Radioactive Waste Management Manual, DOE Manual 435.1, U.S. Department of Energy, Washington, DC.

DOE 2011, DOE Standard - Derived Concentration Technical Standard, DOE-STD-1196-2011, U.S. Department of Energy, Washington, D.C. April 2011.

DOE 2013, DOE Standard - Radioactive Waste Management Disposal Authorization Statement Technical Basis Documentation, DOE-STD-XXXX-XXX, Draft (6/13/13), U.S. Department of Energy, Washington, DC.

EPA 1993, External Exposure to Radionuclides in Air, Water, and Soil, Federal Guidance Report No. 12. EPA 402-R-93-081. U.S. Environmental Protection Agency, Washington, DC. 
FBP 2013. Methods for Conducting Human Health Risk Assessments and Risk Evaluations at the Portsmouth Gaseous Diffusion Plant Piketon, Ohio, FBP-ER-RCRA-WD-RPT-0035, Revision 6, FluorB\&W Portsmouth LLC. December 2013.

FBP 2014a. Remedial Investigation and Feasibility Study Report for the Site-Wide Waste Disposition Evaluation Project at the Portsmouth Gaseous Diffusion Plant, Piketon, Ohio, FBP-ER-RIFS-WD-RPT0030, Revision 5, Fluor-B\&W Portsmouth LLC. February 2014.

FBP 2014b. Performance Assessment for the CERCLA Disposal Facility at the Portsmouth Site, Draft, Fluor-B\&W Portsmouth LLC. April 2014.

FFS 2003. Exposure Scenarios and Unit Dose Factors for Hanford Tank Waste Performance Assessments, HNF-SD-WM-TI-707, Rev. 3, Fluor Federal Services, Richland, WA. July 2003.

GTG 2010, GoldSim User’s Guide, Version 10.5, Service Pack 3, GoldSim Technology Group LLC, Issaquah, WA. December 2010.

IAEA 2010. International Atomic Energy Agency, Handbook of Parameter Values for the Prediction of Radionuclide Transfer in Terrestrial and Freshwater Environments, IAEA Technical Reports Series No. 472, Vienna, Austria, 2010.

ICRP 2008, Nuclear Decay Data for Dosimetric Calculations, ICRP Publication 107, Volume 38, No. 3, International Commission on Radiological Protection. 2008.

Jannik, G. T., Karapatakis, D. J., and Lee, P. L. 2010. Land and Water Use Characteristics and Human Health Input Parameters for use in Environmental Dosimetry and Risk Assessments at the Savannah River Site, SRNL-STI-2010-00447, Rev. 0, Savannah River National Laboratory, Aiken SC. August 6, 2010.

Kaplan, D. I. 2010. Geochemical Data Package for Performance Assessment Calculations Related to the Savannah River Site, SRNL-STI-2009-00473, Savannah River National Laboratory, Aiken SC. March 15, 2010.

Lee, P. L. 2004, Inadvertent Intruder Analysis Input For Radiological Performance Assessments, WSRCTR-2004-00295, Rev. 0, Savannah River National Laboratory, Aiken SC.

Lee, P. L. and Coffield, T. W. 2008a. Baseline Parameter Update for Human Health Input and Transfer Factors for Radiological Performance Assessments at the Savannah River Site, WSRC-STI-2007-00004, Rev. 3. Washington Savannah River Company, Aiken, SC. February 21, 2008.

Lee, P.L and Coffield, T. W. 2008b. Baseline Parameter Update for Human Health Input and Transfer Factors for Radiological Performance Assessments at the Savannah River Site, WSRC-STI-2007-00004, Rev. 4, Washington Savannah River Company, Aiken, SC. June 13, 2008.

Smith, F. G. and Phifer, M. A. 2013. Inadvertent Intruder Analysis for the Portsmouth on-Site Waste Disposal Facility (OSWDF), SRNL-STI-2013-00443, Rev. 1, Savannah River National Laboratory, Aiken SC. December 2013.

SRNS 2012. Conduct of Engineering, Technical Reviews, Manual E7, Procedure 2.60, Savannah River Nuclear Solutions, Aiken, SC. April 24, 2012. 
PNNL 2003. Pacific Northwest National Laboratory, A Compendium of Transfer Factors for Agricultural and Animal Products, PNNL-13421, Hanford, WA, 2003.

Schroeder, P. R., Dozier, T. S., Zappi, P. A., McEnroe, B. M., Sjostrom, J. W., and Peyton, R. L. 1994. The Hydrologic Evaluation of Landfill Performance (HELP) Model: Engineering Documentation for Version 3, EPA/600/R-94/168b, U.S. Environmental Protection Agency, Office of Research and Development, Washington, D.C. September 1994.

Simpkins, A.A., Howard, L. D., LaPlante, P. A., Mancillas, J. W., and Pensado O. 2008. Description of Methodology for Biosphere Dose Model BDOSE, ML083190829, U.S. Nuclear Regulatory Commission, Washington DC, Rev. 1, November 30, 2008.

Smith, F.G., Hiergesell, R.A., Swingle, R.F., Hamm, L.L. and Phifer, M.A., 2009, Savannah River Site Composite Analysis: Base Case Deterministic Calculations, SRNL-STI-2009-00390, Savannah River National Laboratory, Aiken SC.

SRR 2012. Performance Assessment for the H-Area Tank Farm at the Savannah River Site, SRR-CWDA2010-00128, Rev. 1, Savannah River Remediation, Aiken, SC. November 2012.

Stone, D. K. and Jannik, G. T. 2013. Site Specific Reference Person Parameters and Derived Concentration standards for the Savannah River Site, SRNL-STI-2013-00115, Savannah River National Laboratory, Aiken SC. March 2013.

Swingle, R. F. 2006. Software Quality Assurance Plan for GoldSim ${ }^{\mathrm{TM}}$, G-SQA-A-00011, Rev. 0, Savannah River National Laboratory, Washington Savannah River Company, Aiken, SC. August 30, 2006.

USDA 1970. Ohio Irrigation Guide, U-007-307.37, United States Department of Agriculture (USDA) Soil Conservation Service, USDA Agricultural Research Service, Ohio Agricultural Research and Development Center, Ohio Department of Natural Resources - Division of Lands and Soil, Cooperative Extension Service - The Ohio State University, US Weather Bureau. 1970.

White, M. D. and Oostrom, M. 2000. STOMP Subsurface Transport over Multiple Phases: Theory Guide, PNNL-12030 (UC-2010), Pacific Northwest National Laboratory, Richland, WA. 2000.

White, M. D. and Oostrom, M. 2006. STOMP Subsurface Transport over Multiple Phases, Version 4.0, User’s Guide, PNNL-15782, Pacific Northwest National Laboratory, Richland, WA. 2006.

WSRC 2008. E-Area Low-Level Waste Facility DOE 435.1 Performance Assessment, WSRC-STI-200700306, Rev. 0, Washington Savannah River Company, Aiken, SC. July 2008.

Yu, C., Zielen, A. J., Cheng, J. J., LePoire, D.J., Gnanapragasam, E., Kamboj, S., Arnish, J., Wallo III, A., Williams, W.A., and Peterson H. 2001. User's Manual for RESRAD Version 6, ANL/EAD-4, Environmental Assessment Division, Argonne National Laboratory, Argonne, Illinois. July 2001. 